\title{
Evaluation of Factors that Influence Estimated Zones of Transport for Six Municipal Wells in Clark County, Washington
}

\section{U.S. GEOLOGICAL SURVEY}

Water-Resources Investigations Report 97-4224

Prepared in cooperation with INTERGOVERNMENTAL RESOURCE CENTER, CLARK COUNTY, WASHINGTON 


\title{
Evaluation of Factors that Influence Estimated Zones of Transport for Six Municipal Wells in Clark County, Washington
}

\author{
By Leonard L. Orzol and Margot Truini
}

\section{U.S. GEOLOGICAL SURVEY}

Water-Resources Investigations Report 97-4224

Prepared in cooperation with

INTERGOVERNMENTAL RESOURCE CENTER, CLARK COUNTY, WASHINGTON 


\title{
U.S. DEPARTMENT OF THE INTERIOR BRUCE BABBITT, Secretary
}

\author{
U.S. GEOLOGICAL SURVEY \\ Charles G. Groat, Director
}

The use of trade, product, or firm names in this publication is for descriptive purposes only and does not imply endorsement by the U.S. Government.

For additional information write to:

District Chief

U.S. Geological Survey

10615 S.E. Cherry Blossom Drive

Portland, OR 97216-3159

E-mail: info-or@usgs.gov
Copies of this report can be purchased from:

U.S. Geological Survey

Branch of Information Services

Box 25286

Denver, CO 80225-0286

E-mail: infoservices@usgs.gov 


\section{CONTENTS}

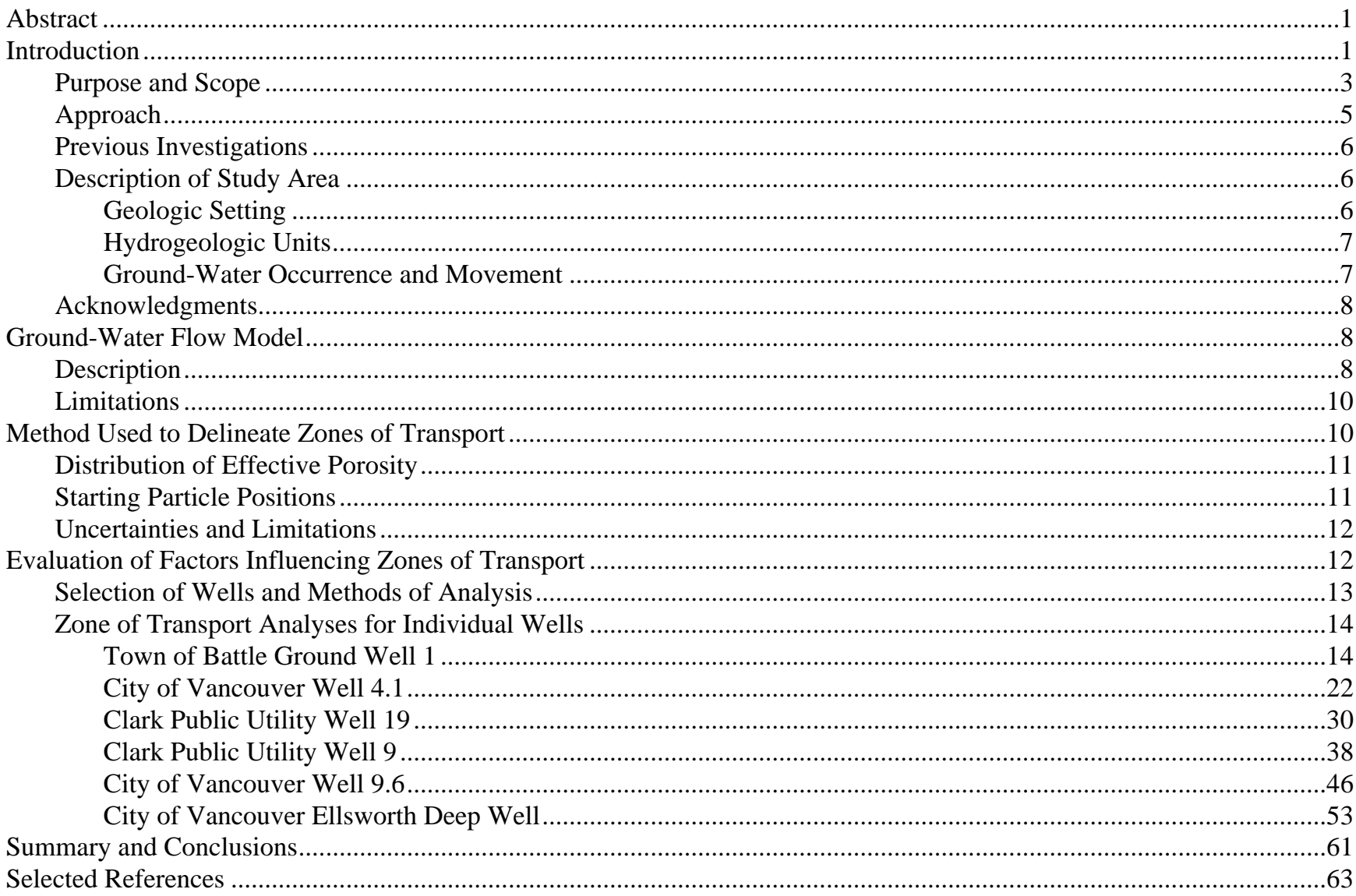

\section{FIGURES}

1. Location of the study area and the boundary for the Portland Basin model...............................................................2

2. Schematic diagram showing zones of contribution, influence, and transport, under sloping water-table conditions ..........4

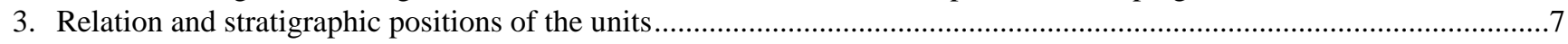

4. Map of study area showing ground-water flow model grid and modeled hydrogeology ...............................................

5. Simulated baseline conditions in layers 1 and 2, near well BG-1 ........................................................................15

6. Projected zones of transport for well BG-1, under baseline conditions ....................................................................17

7. Projected zones of transport for well BG-1, under different hydrologic conditions .......................................................19

8. Simulated baseline conditions in layer 1, near well CV-4 1 ...............................................................................23

9. Projected zones of transport for well CV-4.1, under baseline conditions .....................................................................24

10. Projected zones of transport for well CV-4.1, under different simulated hydrologic conditions ....................................27

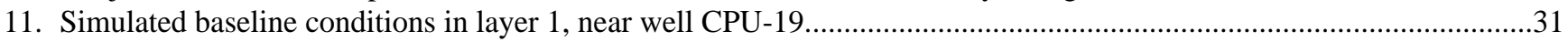

12. Projected zones of transport for well CPU-19, under baseline conditions ..................................................................33

13. Projected zones of transport for well CPU-19, under different simulated hydrologic conditions.......................................35

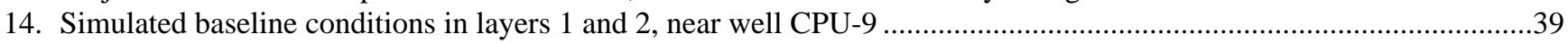

15. Projected zones of transport for well CPU-9, under baseline conditions .....................................................................41

16. Projected zones of transport for well CPU-9, under different simulated hydrologic conditions......................................43

17. Simulated baseline conditions in layers 1 and 2, near well CV-9.6 ....................................................................4

18. Projected zones of transport for well CV-9.6, under baseline conditions ...................................................................48

19. Projected zones of transport for well CV-9.6, under different simulated hydrologic conditions ...................................51

20. Simulated baseline conditions in layers 5 through 7 , near well CV-ED ..................................................................55

21. Projected zones of transport for well CV-ED, under baseline conditions .......................................................................57

22. Projected zones of transport for well CV-ED, under different simulated hydrologic conditions......................................59 


\section{TABLES}

1. Effective porosities of hydrogeologic units used in the simulation by the particle-tracking program .............................12

2. Factors affecting the size and shape of zones of contribution and zones of transport....................................................13

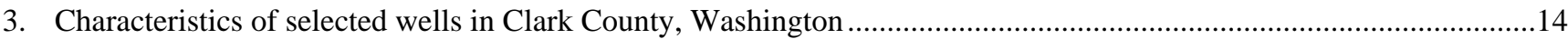

4. Simulated water budget in a selected group of cells in layers 1 and 2 surrounding well BG-1,

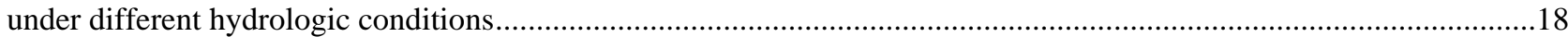

5. Areas of projected zones of transport from simulations for well BG-1 .............................................................20

6. Simulated water budget in a selected group of cells in layer 1 surrounding well CV-4.1,

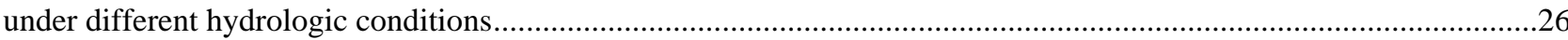

7. Areas of projected zones of transport from different simulations for well CV-4.1 …................................................28

8. Simulated water budget in a selected group of cells in layer 1 surrounding well CPU-19, under different hydrologic conditions

9. Areas of projected zones of transport for different simulations for well CPU-19.......................................................36

10. Simulated water budget in a selected group of cells in layers 1 and 2 surrounding well CPU-9, under different hydrologic conditions

11. Areas of projected zones of transport from different simulations for well CPU-9

12. Simulated water budget in a selected group of cells in layers 1 and 2 surrounding well CV-9.6, under different hydrologic conditions

13. Areas of projected zones of transport from different simulations for well CV-9.6

14. Simulated water budget in a selected group of cells in layers 5 through 7 surrounding well CV-ED,

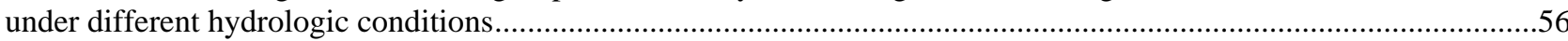

15. Areas of projected zones of transport from different simulations for well CV-ED. 


\title{
Evaluation of Factors that Influence Estimated Zones of Transport for Six Municipal Wells in Clark County, Washington
}

\author{
By Leonard L. Orzol and Margot Truini
}

\section{ABSTRACT}

A ground-water flow model was used in conjunction with particle tracking to estimate zones of transport for six municipal well sites in Clark County, Washington. A zone of transport for a well is a three-dimensional volume within a ground-water system that contains all of the ground water that will discharge from that well within a specified time period. All of the zones of transport for a well compose the zone of contribution for the well. Zones of transport and contribution are important considerations in the delineation of wellhead-protection areas. Hydrogeologic factors, such as hydraulic conductivity and porosity, influence the shape and size of the zones of transport, and, therefore, uncertainty in these and other factors can lead to uncertainty in the delineation of the zones of transport. The sensitivity of the zones of transport to uncertainty in selected hydrogeologic factors was evaluated for the six wells. Estimates of the zones of transport were delineated by the U.S. Geological Survey program MODTOOLS from three-dimensional pathlines computed by the U.S. Geological Survey program MODPATH. Input to MODPATH came from steady-state simulations calculated by the U.S. Geological Survey modular three-dimensional finite-difference ground-water flow model, MODFLOW. Three-dimensional modeling is the best method for delineating zones of transport within stratigraphically complex, heterogeneous, anisotropic aquifers that have complex boundary conditions such as streams and multiple, simultaneously discharging wells.

In this study, zones of transport were delineated by using simulated particle locations computed from the results of a three-dimensional steady-state regional model for $0-0.5,0.5-1,1-5,5-10,10-20$, and 20-50 year travel times to the selected wells. Zones of transport for a well were delineated by tracking particles along pathlines in the reverse direction of ground-water flow.

Sensitivity of the zones of transport to change in the discharge rate of the selected well, porosity, and hydraulic conductivity, as well as to the presence or absence of interfering wells, was evaluated at six well sites to evaluate the effect of uncertainties in these factors on the size and shape of zones of transport. Uncertainty in porosity contributed the most to the uncertainty in delineating the zones of transport. Uncertainty in other factors, such as well dis- charge rate and horizontal hydraulic conductivity, had measurable effects on the zones of transport, but errors introduced through these factors were less significant. Insight into the causes of the changes in the size and shape of the zones of transport to varying conditions was gained by evaluating the simulated water budget and ground-water levels in the vicinity of the well. Changes in the simulated water budget and ground-water levels provided information to better understand the effects of uncertainties in the data on simulation results. The results of this study suggest that ground-water velocity is the underlying control on the size of the zones of transport. The regional hydraulic gradient is the most significant factor controlling the shape and orientation of the zones of transport. Spatial variation in recharge, discharge, and hydraulic properties can also affect the shape of the zones of transport, however. Underestimation of porosity or overestimation of horizontal hydraulic conductivity leads to overestimation of ground-water velocity and overestimation of the size of zones of transport. Overestimation of porosity or underestimation of horizontal hydraulic conductivity leads to underestimation of ground-water velocity and underestimation of the size of zones of transport. Well discharge rate affects ground-water velocities near the well. Underestimation of discharge (and therefore velocities) will result in underestimation of the size of the zones of transport. The sensitivity of estimated zones of transport to uncertainty in parameters such as porosity and horizontal hydraulic conductivity is a function of the well discharge rate and the proximity of the well to boundaries, such as streams and rivers.

\section{INTRODUCTION}

Ground water is the sole source of water to municipal-supply systems in Clark County, Washington (fig. 1), where water demand is increasing as a result of population growth. Government officials and citizens of Clark County have recognized the need for water managers to know the horizontal and vertical extent of the aquifers that contribute ground water to public-supply wells in order to apply methods of protecting ground-water resources from contamination. 


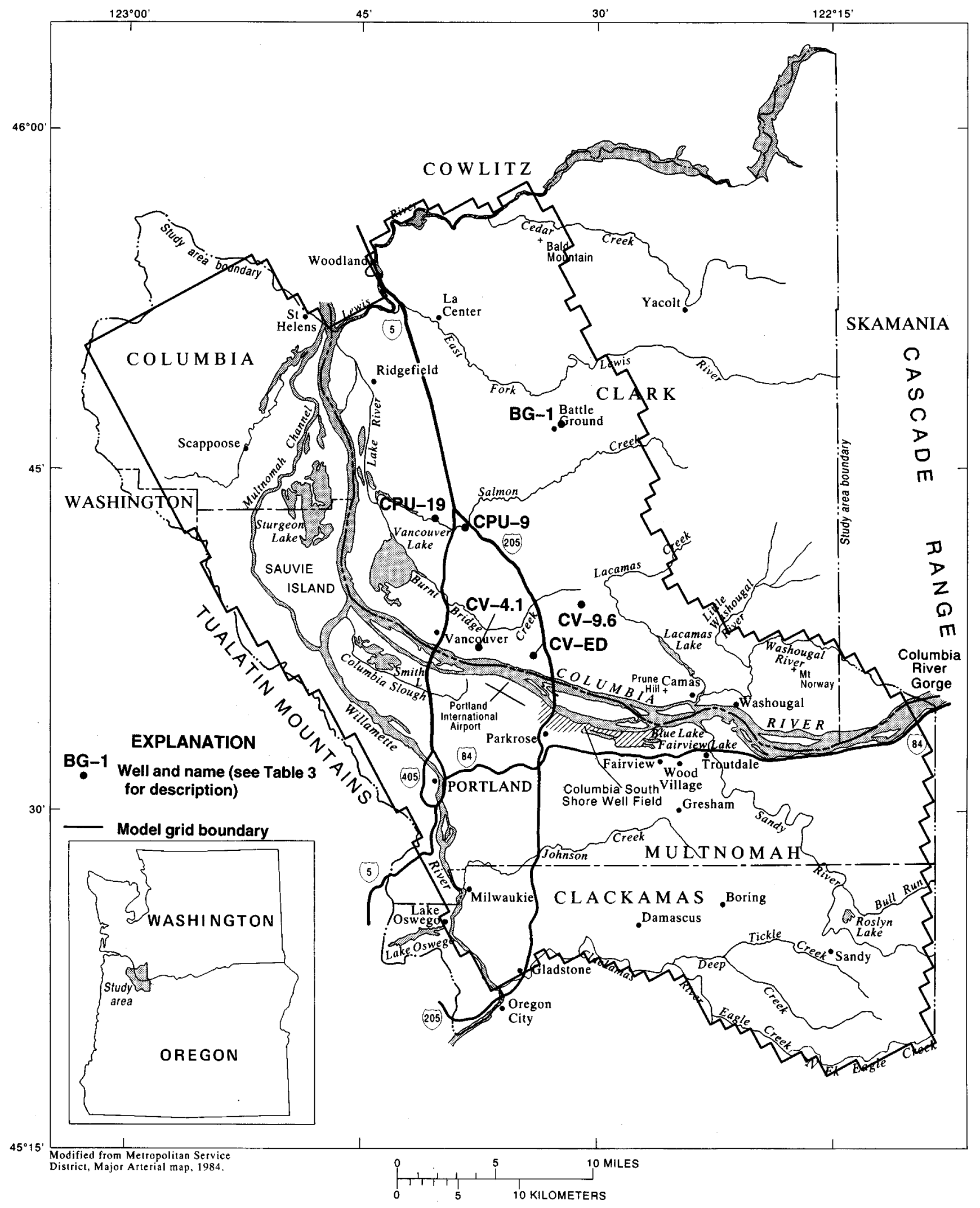

Figure 1. Location of the study area and the boundary for the Portland Basin model. 
Under the 1986 amendments to the Safe Drinking Water Act of 1974, the U.S. Environmental Protection Agency (USEPA) established the Wellhead Protection Program, which was designed to protect public-supply wells from contamination that might adversely affect human health. The USEPA published a guidance document describing techniques for delineating wellheadprotection areas surrounding a well or well field (U.S. Environmental Protection Agency, 1987). The officials and citizens of Clark County successfully petitioned the State of Washington for funds to develop a wellhead-protection program designed to protect public-supply wells in the county.

The first step in developing the wellheadprotection program was to obtain a better understanding of the hydrogeology of the aquifers in the region and to quantify the ground-water flow system. In 1987, the U.S. Geological Survey (USGS) began a cooperative study with the City of Portland Bureau of Water Works, the Oregon Water Resources Department, and the Intergovernmental Resource Center (in Clark County) to describe and quantify the ground-water resources in the Portland Basin. One of the products of that study was a steady-state, three-dimensional ground-water flow model of the Portland Basin (Morgan and McFarland, 1996) (hereafter referred to as the Portland Basin model). The model was intended to (1) test and refine the conceptual understanding of the flow system, (2) estimate the effects of past and future changes to ground-water recharge and discharge on ground-water levels and streamflow, and (3) determine priorities for ground-water monitoring and data-collection that would facilitate improvements in the utility and accuracy of the model.

The next step in developing the wellheadprotection program for Clark County was to delineate areas, or zones, within the aquifer that contribute ground water to each municipal well; these are termed "zones of contribution." A zone of contribution is composed of zones of transport for specified times of travel (fig. 2). Time of travel is the amount of time necessary for a particle of water to travel along a flow path to a discharging well. Each zone of transport within a zone of contribution contains ground water that will reach the well within a specified period of time. A zone of transport can be used to define a protection area, or volume, for a well or well field. In such an area, activities that have a potential to introduce microbial or chemical contaminants into the ground-water flow system that will reach the well within a given time interval could be restricted or controlled.
In 1990, the USGS began a cooperative study with the Intergovernmental Resource Center to develop and demonstrate a method for delineating zones of transport to public-supply wells in Clark County, Washington. The method uses particle tracking to delineate estimates of the zones of transport to discharging wells and evaluates the effects of uncertainty in hydrologic factors on estimates of zones of transport in a hydrologic system. The study used an available numerical model of the Portland Basin (Morgan and McFarland, 1996) and particle tracking methods to delineate and evaluate zones of transport to six municipal wells. Although particle tracking has been available as a modeling tool for some time, a new computer program was developed for this study that has the advantage of being able to store the results of the particle-tracking simulations in a geographic information system (GIS). The program, MODTOOLS (Orzol, 1997), stores output from the particle-tracking program in a GIS containing spatial and descriptive information about particle paths and particle starting and ending points. The GIS was used to display and analyze the results, which, when combined with information such as the locations of public-supply wells and stream reaches, provides new ways to evaluate the sensitivity of the zones of transport to wells and the simulated water budget in the vicinity of the well to uncertainty in hydrologic factors.

\section{Purpose and Scope}

The purpose of this report is to describe the method used to delineate zones of transport from particle-tracking data and to demonstrate the method for six public-supply wells. These six well sites represent typical hydrologic conditions that occur in Clark County, Washington. This report documents a technique for determining zones of transport for selected times of travel, but does not advocate how these zones of transport should be used for delineating wellheadprotection areas.

The study had three phases: (1) use of a numerical ground-water flow model to simulate the dynamics of the ground-water flow system, (2) use of particletracking techniques to delineate zones of transport to discharging wells for 0.5-, 1-, 5-, 10-, 20-, and 50-year travel times, and (3) evaluation of factors such as the discharge rate of the selected well, the number of discharging wells (interfering wells), and cell porosity and horizontal hydraulic conductivity on the size and shape of the zones and the simulated water budget. 


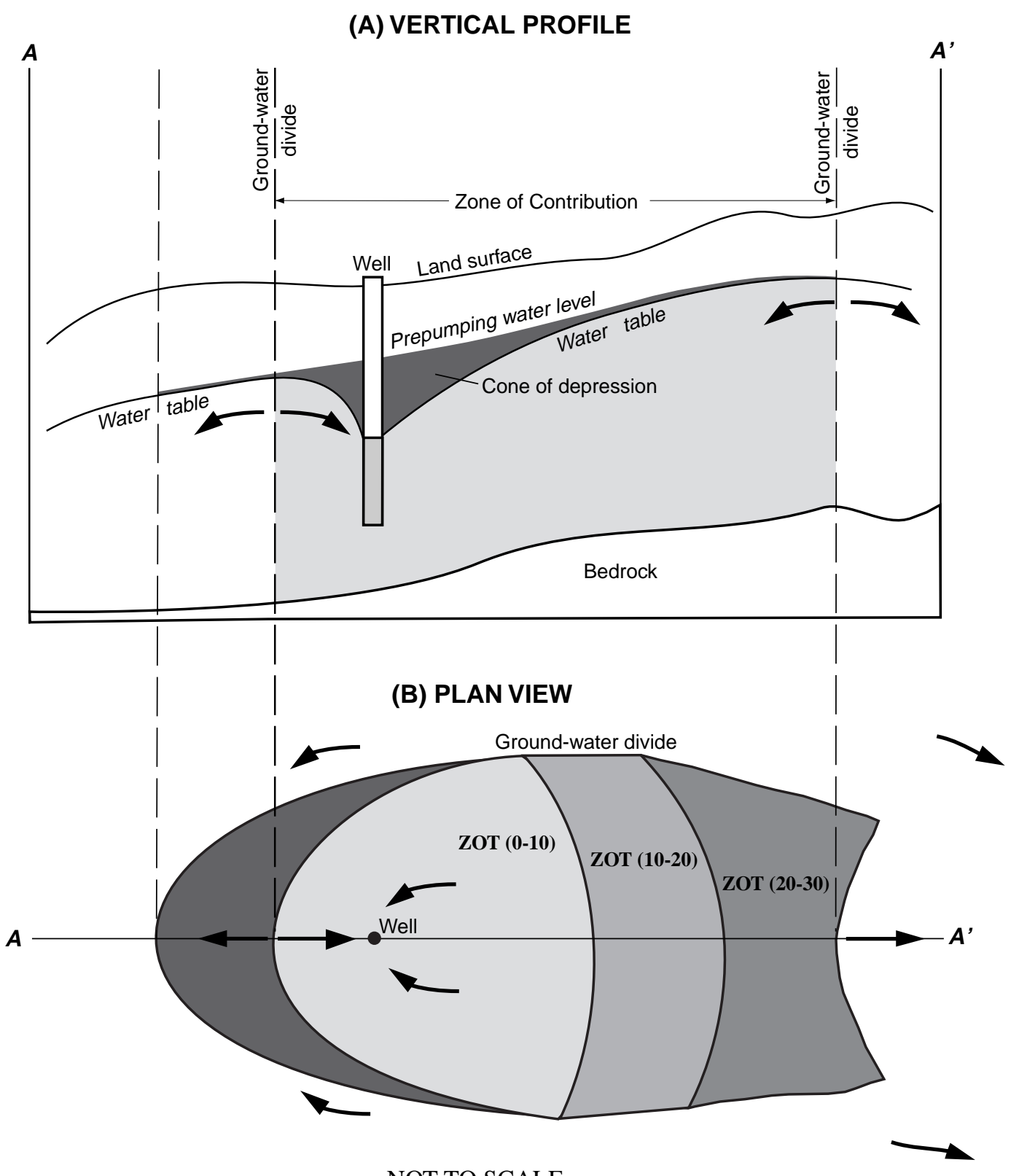

NOT TO SCALE

EXPLANATION

Zone of transport

$0-10$ Years

10-20 Years

20-30 Years
Cone of depression

ZOT (20) — Zone of transport boundary--Number in parentheses is time of travel, in years

$\longrightarrow$ Direction of ground-water flow

Figure 2. Schematic diagram showing zones of contribution, influence, and transport, under sloping water-table conditions (modified from Hansen, 1991). 


\section{Approach}

This study used a calibrated ground-water flow model and particle-tracking software to estimate the zones of transport to wells for 0.5-, 1-, 5-, 10-, 20-, and 50-year travel times, and to evaluate the effects of uncertainty in hydrologic factors on the size and shape of the zones and in the simulated water budget. Hydrologic factors included the discharge rate of the selected well, the number of discharging wells in the vicinity (potentially interfering wells), cell porosity, and horizontal hydraulic conductivity. The methods used in this study are directly applicable to other groundwater systems that have been evaluated using the USGS modular three-dimensional finite-difference ground-water flow model MODFLOW of McDonald and Harbaugh (1988).

Particle tracking is a method of calculating the advective movement of hypothetical water particles through a simulated ground-water flow system. The particle-tracking program computes the position of a particle in the saturated zone after specified periods of time using the ground-water velocity distribution, as determined by a ground-water flow model and estimates of effective porosity. A particle can be started and followed forward in time from any point as it moves downgradient toward a discharge area, or it can be tracked upgradient backwards in time from any point toward a recharge area, as was done in this study. (The paths of imaginary particles of water moving through the simulated ground-water system are referred to as "pathlines.") In addition, the particletracking program can record the particle positions along a pathline for specified travel times. This study used the USGS three-dimensional particle-tracking post-processing package MODPATH, version 1.2, (Pollock, 1989). At the time of this study, MODPATH could only use the results of a ground-water flow model developed for steady-state conditions, such as the ground-water flow model developed for the Portland Basin. A more recent version of MODPATH (Pollock, 1994) has the capability of simulating transient conditions.

The ground-water flow model developed for the Portland Basin (Morgan and McFarland, 1996) that simulated the steady-state conditions for the stresses existing during the period 1987-88 was used to provide input to the particle-tracking program. The results of the particle-tracking program were then processed by a new post-processing program, called MODTOOLS, that stores information in a GIS database (Orzol, 1997).
This database contains all the information calculated by the particle-tracking program, including spatial information such as the path traversed by the particles, starting and ending positions, and intermediate positions at specified times of travel of the particles. Information such as hydrogeologic unit traversed, travel time from one location to another, and particle velocity also is stored.

Of the 6 public-supply wells analyzed in this study, 5 were existing wells selected from 55 publicsupply wells in Clark County, and one was a proposed well at the time of the study. The wells were selected to represent a range of hydrogeologic settings found in Clark County. Particles were placed in the cells of the ground-water flow model that represented the open (perforated or screened) interval of the well. Flow paths to each cell were determined by tracking the particles backwards to their recharge points. A recharge point is defined as the point at which water enters the saturated part of the ground-water flow system. Particle positions were recorded at points along a pathline for 0.5-, 1-, 5-, 10-, 20-, and 50-year travel times and at the recharge point. A utility within the MODTOOLS program analyzed these particle positions and then delineated zones of transport to each well and stored the information in a GIS database. The computer program ZONEBUDGET (Harbaugh, 1990a) was used to sum the simulated water budget for a group of cells surrounding the zones of transport to each well.

For each of the six wells, zones of transport were delineated using the calibrated Portland Basin model to establish baseline conditions. Then, the effect of uncertainty in hydrologic factors such as the discharge rate of the well, the discharge of other wells (interfering wells), and cell porosity and horizontal hydraulic conductivity on the size and shape of the zones of transport and on the simulated water budget were evaluated for each well. The effects were measured by varying each factor individually and comparing the size and shape of the zones of transport and the simulated water budget with those of the baseline simulation. Changing some factors, such as horizontal hydraulic conductivity, altered the ground-water flow model to the extent that the model was moved out of calibration. Nonetheless, these simulations were useful for demonstrating the effects of uncertainty in these parameters and their influence on the estimated zones of transport.

Evaluating the sensitivity of the zones of transport for a well to interfering wells in the ground-water 
flow model was done by excluding all well discharge except for that of the well of interest. Removal of all other wells is, of course, an unrealistic condition, but flow paths for any well are affected by stresses on the ground-water system, such as discharging wells, even those imposed at locations distant from the well of interest. The simulated changes in the size and shape of the zones of transport under this unlikely scenario provide insight into the general effect of other discharging wells, but the results cannot be used for any quantitative purpose.

\section{Previous Investigations}

Particle-tracking techniques, such as WellHead Protection Area models (U.S. Environmental Protection Agency, 1990) and MODPATH (Pollock, 1989), provide a means to better understand the flow of water and the transport of contaminants within a groundwater flow system simulated by numerical models. Numerical models have been used to define the size and shape of a zone of contribution by determining the distribution of drawdown and the direction of groundwater flow caused by a discharging well (Mazzaferro, 1989; Morrisey, 1989). Particle-tracking techniques have been used to evaluate the advective component in transport models (Konikow and Bredehoeft, 1978; Prickett and others, 1981), to define capture zones, zones of contribution, or zones of transport around a discharging well (Shafer, 1987; Bair and others, 1990; Hutchinson, 1990; Bair and others, 1991; Delin and Almendinger, 1991; Hansen, 1991; Bair and Roadcap, 1992; Springer and Bair, 1992), and to define sources of water flowing into an aquifer and the recharge areas (Barlow, 1989, 1993; Buxton and others, 1991; Reilly and Pollock, 1993).

\section{Description of Study Area}

Clark County encompasses $628 \mathrm{mi}^{2}$ (square miles) in southwestern Washington and is bounded by the Lewis River to the north, the Columbia River to the south and west, and the foothills of the western side of the Cascade Range to the east (fig. 1). Clark County lies within a sediment-filled structural basin known as the Portland Basin. The hydrogeology of the Portland Basin has been the focus of several recent investigations by the USGS (McCarthy and Anderson, 1990; Swanson and others, 1993; Collins and Broad, 1993; Snyder and others, 1994; Morgan and McFarland, 1996; McFarland and Morgan, 1996) that form the foundation for much of the work presented here.

The topography of Clark County is characterized by flat-lying alluvial lands along the Columbia River and its tributaries that are broken by low, rolling hills or buttes with benches and hilly areas that rise to meet the foothills of the Cascade Range to the east and northeast. Altitude of the land surface ranges from about $10 \mathrm{ft}$ (feet) along the Columbia River to about $3,000 \mathrm{ft}$ in the foothills of the Cascade Range. The Columbia River flows westward out of the Columbia River Gorge until it passes the city of Vancouver, Washington, where it flows northward. The tributaries to the Columbia River that drain Clark County include the Lewis, East Fork Lewis, Lake, Little Washougal, and Washougal Rivers, and Cedar, Salmon, Burnt Bridge, and Lacamas Creeks.

The city of Vancouver is the major urban area of the county and had a population of about 47,000 in 1992. Other cities and towns include Camas, Washougal, Battle Ground, Ridgefield, La Center, and Yacolt. The total population of Clark County in 1992 was about 258,000 .

The climate of Clark County is temperate, with dry, moderately warm summers and wet, mild winters, although the topography of the area produces considerable variations in the local climate. The average temperature for Vancouver is about $52^{\circ} \mathrm{F}$ (degrees Fahrenheit) and ranges from about $38^{\circ} \mathrm{F}$ in January to about $66^{\circ} \mathrm{F}$ in July. Precipitation in Clark County ranges from about $41 \mathrm{in} / \mathrm{yr}$ (inches per year) near Vancouver to more than $100 \mathrm{in} / \mathrm{yr}$ in the western Cascade Range. About 58 percent of Clark County is forested, about 21 percent consists of urban lands, about 15 percent consists of agricultural lands, and about 6 percent is classified as other land-use types.

\section{Geologic Setting}

The overviews of the geology and hydrology of the Portland Basin presented in the following sections summarize more detailed descriptions in reports by (1) Swanson and others (1993), who discuss the thickness, extent, and lithology of hydrogeologic units in the basin, (2) McFarland and Morgan (1996), who describe the ground-water flow system of the basin, including its boundaries, hydraulic characteristics, and components of recharge and discharge, and (3) Morgan and McFarland (1996), who discuss the geology and hydrology as it relates to simulation of the ground-water flow system using numerical modeling. 
The northwest-trending Portland Basin was formed by structural deformation of the underlying Eocene and Miocene volcanic and marine sedimentary rocks. Late Miocene and younger fluvial and lacustrine sediments are overlain by unconsolidated Pleistocene catastrophic flood deposits and Holocene Columbia River alluvium (Trimble, 1963; Mundorff, 1964; Swanson and others, 1993; McFarland and Morgan, 1996). The consolidated and unconsolidated basin-fill sediments are thickest adjacent to the Columbia and Willamette Rivers, where they may be as much as $1,800 \mathrm{ft}$ thick.

\section{Hydrogeologic Units}

Hydrogeologic units in the Portland Basin, as defined by Morgan and McFarland (1996) and used in their model of the ground-water flow system, may comprise one or more geologic units. From youngest to oldest the eight hydrogeologic units delineated within the basin were the:

1. Unconsolidated sedimentary aquifer

2. Troutdale gravel aquifer

3. Confining unit 1

4. Troutdale sandstone aquifer

5. Confining unit 2

6. Sand and gravel aquifer, upper coarse-grained subunit

7. Sand and gravel aquifer, lower fine-grained subunit

8. Older rocks

A ninth unit, the undifferentiated fine-grained deposits, is mapped where the Troutdale sandstone aquifer is missing and confining units 1 and 2 cannot be differentiated. The undifferentiated fine-grained deposits may be as young as confining unit 1 . The relation and stratigraphic positions of the units used throughout this report are shown in figure 3.

\section{Ground-Water Occurrence and Movement}

Recharge to the Portland Basin is primarily through the infiltration of precipitation. However, runoff into drywells, and on-site waste-disposal systems are locally important sources of recharge. Estimated recharge over the modeled area of the Portland Basin from these three sources ranges from 0 to $49 \mathrm{in} / \mathrm{yr}$ with a mean of $22 \mathrm{in} / \mathrm{yr}$ (Snyder and others, 1994). Irrigation return flow and losing streams may constitute locally important sources of seasonal recharge, but are insignificant on a regional scale

\begin{tabular}{|c|c|}
\hline \multicolumn{2}{|c|}{ Unconsolidated sedimentary aquifer } \\
\hline \multicolumn{2}{|c|}{ Troutdale gravel aquifer } \\
\hline $\begin{array}{l}\text { Undifferentiated } \\
\text { fine-grained } \\
\text { deposits }\end{array}$ & Confining unit 1 \\
\cline { 2 - 2 } & $\begin{array}{l}\text { Troutdale sandstone } \\
\text { aquifer }\end{array}$ \\
\cline { 2 - 2 } & Confining unit 2 \\
\hline \multicolumn{2}{|c|}{$\begin{array}{l}\text { Sand and gravel aquifer, } \\
\text { upper coarse-grained subunit }\end{array}$} \\
\hline \multicolumn{2}{|c|}{$\begin{array}{l}\text { Sand and gravel aquifer, } \\
\text { lower fine-grained subunit }\end{array}$} \\
\hline \multicolumn{2}{|c|}{ Older rocks } \\
\hline
\end{tabular}

Figure 3. Relation and stratigraphic positions of the units.

Large capacity wells located near the Columbia River also can induce recharge from the river to the shallow alluvial aquifers (McCarthy and others, 1992; Morgan and McFarland, 1996).

Movement and discharge of ground water is primarily controlled by the topography of the basin, which creates regional, intermediate, and local ground-water flow systems. The Columbia River is the regional discharge area for the ground-water flow system in Clark County. Much of the ground water discharging to the river from Clark County enters the system in upland recharge areas along the western Cascade Range, moves downward and horizontally toward the river, and finally moves upward to discharge to the river. The Lewis River, East Fork Lewis River, and Salmon Creek are examples of discharge areas for intermediate ground-water flow systems. Local ground-water flow systems are much smaller, with distances on the order of only hundreds of feet between recharge and discharge areas (Morgan and McFarland, 1996).

Ground-water discharge in the Portland Basin is primarily to streams, rivers, wells, and springs (McFarland and Morgan, 1996). The largest component of ground-water discharge in the Portland Basin is to streams and rivers. Ground-water withdrawals from wells in Clark County are primarily used for industry and public supply, with smaller amounts used for irrigation and domestic purposes (Collins and Broad, 1993). The major springs in southwestern Clark County are located along the north side of the Columbia River between Vancouver and Prune Hill. 


\section{Acknowledgments}

The authors would like to thank Rod Swanson and Earl Rowell of the Water Quality Division in the Department of Community Development of Clark County, Washington, for providing assistance in the completion of this investigation. Appreciation is expressed to Daniel T. Snyder of the U.S. Geological Survey for his support during the development of the computer software. The authors also wish to thank Frank A. Packard and David S. Morgan, both of the U.S. Geological Survey, for their guidance in documenting the particle-tracking techniques used in this investigation and for their reviews of this report.

\section{GROUND-WATER FLOW MODEL}

\section{Description}

A three-dimensional, regional ground-water flow model of the Portland Basin (including most of Clark County), constructed and calibrated to steadystate time-averaged conditions for the period 198788 during a previous USGS study (Morgan and McFarland, 1996), was used in this investigation. Morgan and McFarland (1996) adjusted recharge rates in their time-averaged simulation to account for changes in ground-water storage that occurred during the 1987-88 calibration period. These adjustments were removed for the simulations made in this study so as to simulate true steady-state conditions.

Morgan and McFarland (1996) used the USGS modular three-dimensional finite-difference groundwater flow model by McDonald and Harbaugh (1988) with enhancements by Orzol and McGrath (1992) to simulate ground-water flow and to test and refine the conceptual understanding of the flow system in the Portland Basin. The active cells of the model grid cover $981 \mathrm{mi}^{2}$ of the Portland Basin and include most of Multnomah County, Oregon and about one half of Clark County, Washington, as well as parts of Clackamas, Washington, and Columbia Counties in Oregon and Skamania County in Washington (fig. 4). The y-axis of the model is oriented 28.8 degrees west of north to align it with the predominant direction of ground-water flow. The finite-difference model of the basin was constructed by dividing the nine hydrogeologic units delineated by Morgan and McFarland (1996) into eight model layers. Each model layer is subdivided by a rectilinear grid that consists of 3,040 active cells with a uniform grid-cell spacing of 3,000 ft (a cell area of $0.32 \mathrm{mi}^{2}$ ) and a variable thickness. Hydrogeologic units are not restricted to a single model layer, but may span multiple model layers.

The hydraulic characteristics of the rocks and sediments that form aquifers and confining beds of the ground-water system control the direction and velocity of ground-water movement within the system. Estimates of horizontal hydraulic conductivity were made by McFarland and Morgan (1996) from multiple-well aquifer tests, single-well tests, and published data. These distributions were used as initial values that were subsequently modified during calibration of the numerical model to achieve a best fit between simulated and observed data. The median values of hydraulic conductivity range from about $0.1 \mathrm{ft} / \mathrm{d}$ (feet per day) for the older rocks to about $100 \mathrm{ft} / \mathrm{d}$ for the unconsolidated sedimentary aquifer. Vertical anisotropy ratios of hydraulic conductivities (horizontal to vertical) were estimated for each hydrogeologic unit from published values for similar classes of sediments and then were modified during calibration of the numerical model. The vertical anisotropy ratios determined from calibration were 1,000:1 for the older rocks and all fine-grained units (confining unit 1 , confining unit 2, lower fine-grained subunit of the sand and gravel aquifer, and undifferentiated finegrained deposits) and 100:1 for the primary aquifer units (unconsolidated sedimentary aquifer, Troutdale gravel aquifer, Troutdale sandstone aquifer, and upper coarse-grained subunit of the sand and gravel aquifer) (Morgan and McFarland, 1996).

The simulated water budget determined by use of the ground-water flow model indicates that recharge to the ground-water flow system from the infiltration of precipitation accounts for 87 percent $\left(1,440 \mathrm{ft}^{3} / \mathrm{s}\right.$ [cubic feet per second]) of the inflow to the basin. Runoff into drywells contributes 4 percent $\left(62 \mathrm{ft}^{3} / \mathrm{s}\right)$, on-site waste-disposal systems contribute 2 percent $\left(27 \mathrm{ft}^{3} / \mathrm{s}\right)$, seepage from smaller rivers and streams contributes 5 percent $\left(88 \mathrm{ft}^{3} / \mathrm{s}\right)$, and seepage from larger rivers and water bodies including the Columbia and Willamette Rivers contribute 3 percent $\left(36 \mathrm{ft}^{3} / \mathrm{s}\right.$ ) (Morgan and McFarland, 1996). Of the $1,440 \mathrm{ft}^{3} / \mathrm{s}$ of ground-water discharge in the basin, 58 percent is discharged to smaller rivers and streams, 27 percent is discharged to the Columbia and Willamette Rivers, 10 percent is discharged to wells, and less than 5 percent is discharged to springs and other sinks (outflows). 


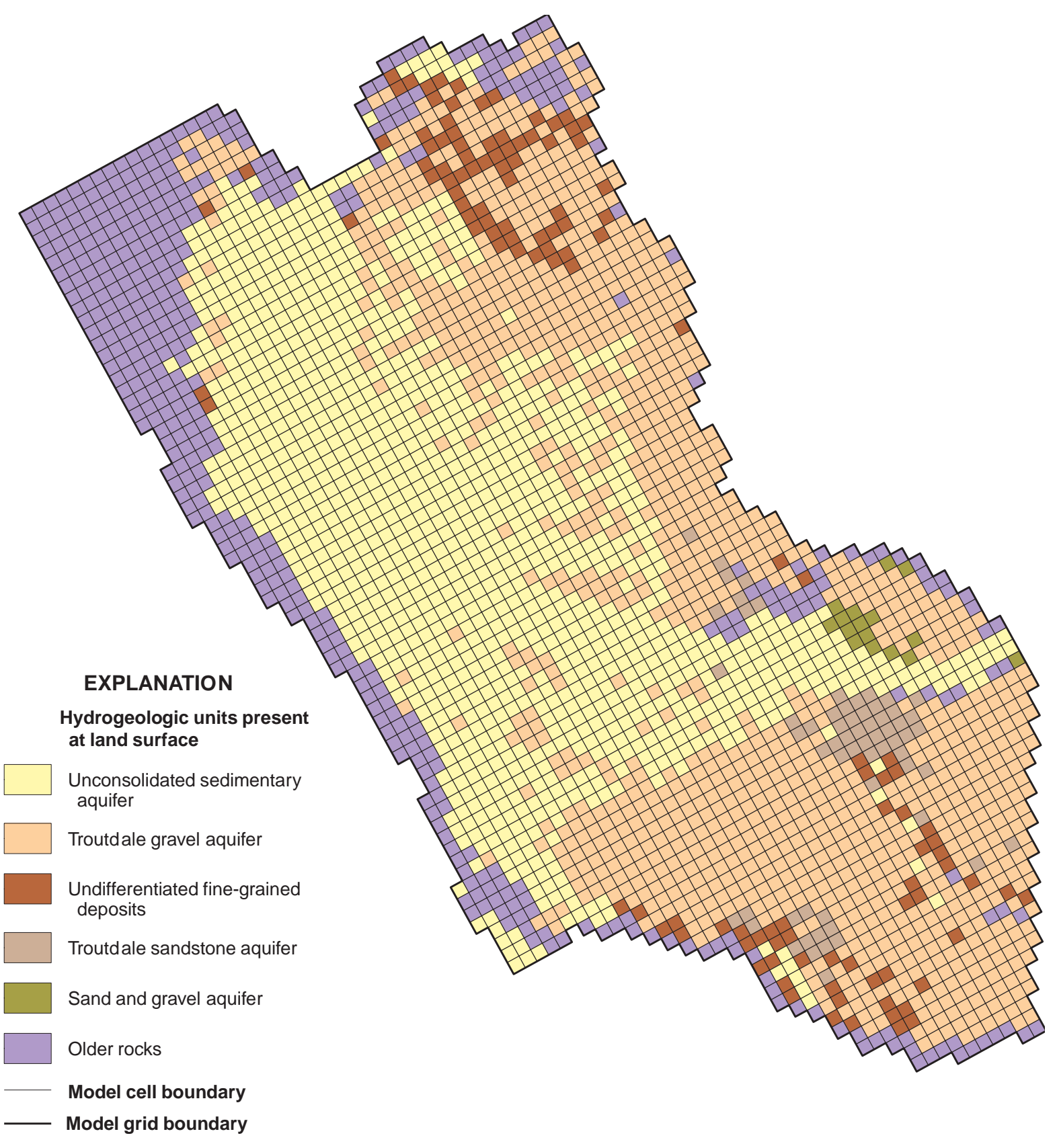

Figure 4. Map of study area showing ground-water flow model grid and modeled hydrogeology. 


\section{Limitations}

Many assumptions are necessary to simplify a hydrogeologic system to the extent that it can be represented by a mathematical model. Some of these assumptions limit the scope of application of the model and the hydrologic questions that can reasonably be addressed. The major simplifying assumptions and the limitations they impose are summarized below from Morgan and McFarland (1996).

The model uses a steady-state simulation of time-averaged conditions for the period 1987-88, including climate, land use, and water use. Because the model has not been calibrated to transient conditions, the model cannot be used to predict the transient response of the system. The limitation imposed by this is that intermediate heads and fluxes in the system, between the time a new stress is applied and the time the system reaches a new steady state, cannot be predicted using the model. The model can, however, be used to simulate steady-state conditions for various stress conditions, and the steady-state water levels and fluxes under various ground-water management conditions can be compared and evaluated on the basis of the eventual effect they would have on the system.

A second limitation on the use of the model is that as constructed, transmissivities of hydrogeologic units do not change when the saturated thickness of the units change. This is not a serious limitation unless new stresses on the system are great enough to cause significant change to the saturated thickness of any unit. A critical examination of model results would be advisable if large water-level changes are simulated in the uppermost hydrogeologic units.

Finally, boundary conditions involve considerable simplification of the hydrologic system and can have substantial effects on model results; thus, a clear understanding of boundary conditions is necessary to avoid serious errors in model application. The lateral boundary of the Portland Basin model was specified as a "no-flow" boundary on the basis of assumptions that it coincided with either ground-water flow divides or low-permeability rocks. These assumptions were considered valid for the stress conditions in the basin during the 1987-88 simulation period; however, careful reevaluation of the conditions would be warranted when simulating other stress conditions.

For many purposes, these limitations do not impose serious constraints on the use of the model. However, care must be used when interpreting the results, as changes in modeled hydrologic conditions can influence the simulated extent of recharge areas, locations of pathlines, and age of ground water.

\section{METHOD USED TO DELINEATE ZONES OF TRANSPORT}

The use of particle-tracking software coupled with numerical models has become an effective tool in delineating zones of transport to wells and quantitatively analyzing ground-water flow systems. MODPATH, the USGS three-dimensional particletracking program developed by Pollock (1989), was used to calculate pathlines. MODPATH was chosen for this study because it (1) simulates particle pathlines within three-dimensional flow models, (2) is widely applied to ground-water investigations, (3) is designed to use input data and results from MODFLOW, and (4) has FORTRAN source code that is available and well documented and that facilitates modification and enhancement. A new computer program called MODTOOLS was developed to replace the plotting part of MODPATH, called MODPATH-PLOT. MODTOOLS translates MODPATH output data on particle coordinates and other attributes (such as velocity, distance and travel time) into the format of ARC/INFO data files (Orzol, 1997). ARC/INFO is a GIS that is capable of displaying and performing operations on spatial features and their associated characteristics. MODTOOLS does not change the method used to calculate particle pathlines, but it enhances the ability to display and analyze the results from MODPATH. This significant improvement enables the use of the database, statistical, and display capabilities of ARC/INFO and facilitates comparison with other types of spatial information.

MODPATH uses a semianalytical particletracking scheme that is based on the assumption that each directional velocity component for a particle of water varies linearly within a grid cell in its own coordinate direction (Pollock, 1989). This assumption allows an analytical expression to be derived that describes the flow path of water within a grid cell. Given the initial position of a particle anywhere in a cell, the pathline and travel time within the cell can be computed directly. Steady-state ground-water heads and intercell flow rates are first determined using MODFLOW. This information is then input to MODPATH along with effective porosity values and user-specified starting particle locations. MODPATH then calculates three-dimensional pathlines and time- 
of-travel information as particles are tracked individually through the simulated flow system, using the calculated distribution of velocity throughout the flow system. MODTOOLS (Orzol, 1997) is used to create digital maps of the delineation of the zones of transport from starting and ending points, and from intermediate points at specified travel times along particle pathlines. These digital maps have associated digital attribute files that contain information such as starting, ending, and intermediate particle positions (model cell, intracell location, altitude, and hydrogeologic unit), travel time, distance, and velocity.

MODTOOLS was used to delineate an approximation of the zones of transport for a pumping well from particle data generated using the time-series option of MODPATH (Pollock, 1994). First, starting particle positions were assigned to the model cells that contained the open interval of the well Second, particles were tracked in the reverse direction of groundwater flow in the backward-tracking mode of MODPATH. At specified travel times, MODPATH recorded spatial location and descriptive information about particle positions along pathlines in a file called TIMESERS. MODPATH also recorded spatial and descriptive information about particle starting and ending points in a file called ENDPOINT. Third, MODTOOLS was used to combine the particle data from the TIMESERS and ENDPOINT files output by MODPATH and to delineate the zones of transport to the selected well.

The delineating algorithm used in MODTOOLS approximates the zone of transport for a travel time by projecting the particles onto a horizontal reference plane and then determining the maximum extent of travel since the last time step within a sector of a circle centered on the cell containing the well (Orzol, 1997). The reference plane is generally a horizontal plane representing the top of the saturated part of the ground-water system. The positions of the particles farthest from the center of the cell containing the well are used to estimate the maximum extent of the zone of transport in each sector to form a polygon representing the zone of transport for that travel time. Particles may travel with velocities that vary widely, distorting the surface of the zone into a complex three-dimensional form that is difficult to project onto a reference plane for the delineation of the zone of transport. The method used by MODTOOLS is documented by Orzol (1997).

\section{Distribution of Effective Porosity}

Effective porosity for each grid cell is used with the results of the flow model by MODPATH to calculate the velocity distribution of the simulated groundwater flow system. The velocity distribution then can be used to determine ground-water flow paths and travel times. The effective porosity values do not have any effect on the location of particle pathlines or the points of particle recharge, however, ground-water velocity (or more precisely, the average interstitial velocity) is inversely proportional to the effective porosity. The three-dimensional distribution of effective porosity for the model was estimated by Hinkle and Snyder (1997) using an empirical relation between hydraulic conductivity and effective porosity developed by Ahuja and others (1989) and modified on the basis of information from Morris and Johnson (1967). These values were further refined by comparing ground-water ages determined through the use of chlorofluorocarbon (CFC)model age dating with ground-water ages calculated by the particle-tracking program (Snyder and others, 1996). A summary of the effective porosities used in this study is presented in table 1 .

\section{Starting Particle Positions}

The user specifies starting particle positions before beginning a particle-tracking analysis. For this study, the starting particle positions were arranged on the surface of a vertical cylinder. The axis of the cylinder passes through the center of the model grid cell containing the well, and the length and diameter of the cylinder are equal to the thickness and width of the cell. Particles are placed around the perimeter of the cylinder in horizontal planes that are equally spaced along the cylinder's vertical length. Also, each successive horizontal plane of particles is rotated clockwise about the vertical axis of the cylinder by:

$$
\frac{360}{n(m-1)} \text { degrees, }
$$

where:

$n$ is the number of particles in the plane, and $m$ is the number of planes.

For this study, 10 planes with 72 particles per plane were specified for each cell. This method of specifying starting particle positions is referred to as the vertical-cylindrical positioning method. 
Table 1. Effective porosities of hydrogeologic units used in the simulation by the particle-tracking program

\begin{tabular}{lcccc}
\hline \multicolumn{1}{c}{ Hydrogeologic unit } & Minimum & Maximum & Mean & $\begin{array}{r}\text { Standard } \\
\text { deviation }\end{array}$ \\
\hline Unconsolidated sedimentary aquifer & 0.19 & 0.31 & 0.31 & 0.005 \\
Troutdale gravel aquifer & .18 & .31 & .28 & .042 \\
Confining unit 1 & .13 & .30 & .19 & .042 \\
Troutdale sandstone aquifer & .18 & .31 & .29 & .033 \\
Confining unit 2 & .13 & .30 & .20 & .043 \\
Sand and gravel aquifer, & & & & .043 \\
$\quad$ upper coarse-grained subunit & .22 & .31 & .28 & .006 \\
Sand and gravel aquifer, & & & & .060 \\
$\quad$ lower fine-grained subunit & .20 & .24 & .24 & .033 \\
Undifferentiated fine-grained deposits & .13 & .31 & .23 & .15 \\
Older rocks & .07 & .18 &
\end{tabular}

\section{Uncertainties and Limitations}

The use of a particle-tracking program is subject to the same limitations previously discussed for the ground-water flow model, as well as limitations inherent to the particle-tracking methodology. The Portland Basin model was designed as a regional flow model. Data collection and ground-water flow simulations were made on the basis of a uniform grid-cell spacing of 3,000 ft. The large grid size will produce enlarged zones of transport for individual cells containing wells compared with those that might be produced by a model with smaller grid blocks. The most appropriate use of the results of the ground-water flow model or particle-tracking program is in a regional context. The results of this particular model may not be applicable to site-specific studies. These studies may require additional information on the hydraulic characteristics of the ground-water flow system at a resolution similar to that of the model discretization required in the area of interest.

MODPATH simulates only the advective transport of water and does not consider hydrodynamic dispersion; neither does it consider retardation of the movement of possible contaminants as a result of adsorption or chemical interactions. MODPATH simulates movement in the saturated zone only. Movement and traveltime through the unsaturated zone (the area between land surface and the water table in which the pores may contain air, water, or both) is not accounted for and may result in an underestimate of the traveltime. Additional limitations of MODPATH are described by Pollock (1989, p. 19-21).

\section{EVALUATION OF FACTORS INFLU- ENCING ZONES OF TRANSPORT}

Many factors affect the size and shape of the zones of contribution and zones of transport for a discharging well (table 2). The effects of several of these factors have been investigated by other workers (Barlow, 1989; Morrissey, 1989). The principle factors evaluated in this study were well discharge rate, aquifer transmissivity, well interference, and porosity. Other factors, such as the proximity of aquifer boundaries and hydraulic gradients near the discharging well, are discussed for each of the six public-supply wells.

Many of the factors that influence the size and shape of zones of transport can vary with time (table 2). Aquifer transmissivity, for example, can change if the saturated thickness of the aquifer changes significantly over time. The effects of these temporally variable factors could not be addressed in this study because the Portland Basin model was not calibrated to transient conditions, and MODPATH version 1.2 was not capable of transient particle-tracking analyses.

A numerical model that simulates steady-state conditions does not portray temporal changes in the ground-water system, only the final result after the system has reached equilibrium with the stresses applied. A zone of contribution estimated for a well under steady-state conditions would be the largest zone of contribution possible for the specific hydrologic conditions. Under transient conditions, however, a zone of contribution increases in area as time passes and as aquifer storage supplies progressively less water to the discharging well (Barlow, 1989). 
Table 2. Factors affecting the size and shape of zones of contribution and zones of transport

\section{Factor}

Well discharge rate ${ }^{1,2}$
Aquifer transmissivity and spatial variation ${ }^{1,2}$
Well interference
$\quad$ (the effect of simultaneous pumping from other wells) ${ }^{1,2}$
Aquifer porosity and spatial variation ${ }^{1}$
Aquifer storage coefficient or specific yield ${ }^{2}$
Proximity of the pumping well to aquifer boundaries
Spatial variations in aquifer recharge ${ }^{2}$
Partial penetration of the pumping well
The presence of extensive confining layers
Ground-water gradient surrounding well and relation of well
$\quad$ location to recharge and discharge areas ${ }^{2}$
${ }^{1}$ Factor evaluated in this study.
${ }^{2}$ Factor that can vary with time.

Sources of water to a well that can change in relative importance over time are (1) removal of ground water from aquifer storage (storage depletion), (2) capture of natural discharge, such as that to a stream, and (3) additional recharge from induced infiltration of surface water, such as nearby streams, rivers, lakes or ponds, (Theis, 1938; Barlow, 1989; Morrisey, 1989). Storage depletion is the primary source of pumped water initially; however, captured discharge and (or) induced infiltration supply increasing proportions until the ground-water system reaches equilibrium (steady-state conditions). The system reaches equilibrium when pumped water is obtained solely from captured ground-water discharge or from induced infiltration.

In order to evaluate the effect of partially penetrating wells, aquifer units in the model would need to be divided into several layers to simulate a well screen at a specific vertical location within an aquifer; the vertical discretization of the model layers for the Portland Basin model (Morgan and McFarland, 1996) was not appropriate in most cases to test this factor.

\section{Selection of Wells and Methods of Analysis}

Of the six public-supply wells evaluated, five existed at the time of the study and one was proposed. Zones of transport were delineated for periods of $0-0.5,0.5-1,1-5,5-10,10-20$, and $20-50$ years to each well. These periods were chosen because planners for Clark County felt that delineating zones of transport for periods up to 50 years would be sufficient to meet any requirements proposed by the Department of Health in the State of Washington.
Information for each well is listed in table 3 , and locations of the selected wells are shown in figure 1. Wells were selected to represent different hydrogeologic conditions found in Clark County and to illustrate the variability of delineating zones of transport for these conditions. The wells and the hydrogeologic conditions unique to each well are (1) the Town of Battle Ground Well 1, where the effects from interfering wells are negligible and the discharge rate of the well is low compared with other wells, (2) the City of Vancouver Well 4.1, where the effects from interfering wells are significant and the discharge rate of the well is high compared with other wells, (3 and 4) Clark Public Utility Wells 19 and 9, where the discharge rates of both wells are about equal, but discharge is from different hydrogeologic units, and the wells are close to one another (within 15,000 ft), (5) the City of Vancouver Well 9.6, which taps aquifers that are part of both local and deep regional flow systems, and (6) City of Vancouver Ellsworth Deep Well, which will discharge from a confined aquifer. The Ellsworth Deep Well was completed in 1991 and will become part of the City of Vancouver municipal water supply system by the year 2000 (Swanson, 1992).

The sensitivity of the size and shape of the zones of transport delineated by using particle tracking was evaluated by varying the discharge rate of the selected well, the number of interfering wells, porosity, and horizontal hydraulic conductivity. The results of the baseline simulation for each selected well were compared to other simulations generated by individually varying, one at a time, discharge rate, interfering wells, porosity, and hydraulic conductivity in an area surrounding each selected well. Seven simulations were made for each well: (1) baseline conditions (1987-88 steady-state), (2) discharge of the well multiplied by a factor of 1.5 (increased-discharge simulation), (3) all wells excluded except the selected well (no-interference simulation), (4) hydraulic conductivity multiplied by a factor of 1.2 (increased-conductivity simulation), (5) hydraulic conductivity multiplied by a factor of 0.8 (decreased-conductivity simulation), (6) porosity multiplied by a factor of 1.4 (increasedporosity simulation), and (7) porosity multiplied by a factor of 0.6 (decreased-porosity simulation). Varying some factors, such as horizontal hydraulic conductivity, altered the ground-water flow model to the extent that the model was moved out of calibration; however, these changes were useful for illustrating the effects of uncertainty in a parameter. 
Table 3. Characteristics of selected wells in Clark County, Washington

[Aquifer type: U, unconfined; C, confined. Discharge rate in $\mathrm{ft}^{3} / \mathrm{s}$, cubic feet per second.]

\begin{tabular}{llccc}
\hline $\begin{array}{c}\text { Well } \\
\text { number }\end{array}$ & \multicolumn{1}{c}{$\begin{array}{c}\text { Well } \\
\text { name }\end{array}$} & $\begin{array}{c}\text { Aquifer } \\
\text { type }\end{array}$ & $\begin{array}{c}\text { Discharge } \\
\text { rate }\end{array}$ & $\begin{array}{c}\text { Nearby } \\
\text { pumping wells }\end{array}$ \\
\hline 03N/02E-03ABA1 & Town of Battle Ground Well 1 (BG-1) & $\mathrm{U}$ & 0.53 & No \\
02N/01E-36ABA1 & City of Vancouver Well 4.1 (CV-4.1) & $\mathrm{U}$ & 8.2 & .85 \\
03N/01E-27CDA1 & Clark Public Utility Well 19(CPU-19) & $\mathrm{U}$ & 1.5 & No \\
03N/01E-35ABA1 & Clark Public Utility Well 9 (CPU-9) & $\mathrm{U}$ & 2.9 & No \\
02N/02E-14DCD & City of Vancouver Well 9.6 (CV-9.6) & $\mathrm{U}$ & 4.7 & Yes \\
02N/02E-33CDA & City of Vancouver Ellsworth Deep Well (CV-ED) C & & \\
& & & & \\
\end{tabular}

Changes in the relative rate of flows in the simulated water budget to natural discharge points and across boundaries were compared. Knowledge of the relative proportions of the volumetric flow rates from and to hydrologic sources and sinks and through cell faces is important in understanding the size and shape of the zones of transport and the sources and relative amounts of water being diverted by each well. The cell-by-cell flow rates were summed using the program, ZONEBUDGET (Harbaugh, 1990a).

Simulated flow rates were summed for the baseline simulation and each of the six other simulations for a selected group of cells surrounding each well. Although the selected cells did not encompass the entire zone of contribution for the selected well, the cells encompassed the largest zone of transport to the well for the baseline simulation and the six other simulations. Changes in the magnitude and direction of the simulated flow rates for the selected cells are indicative of relative changes in the simulated water budget for the entire zone of contribution depending the proximity and nature of nearby boundaries.

The area enclosed by the zones of transport, the local distribution of ground-water levels, and the relative proportions of flow rates from and to hydrologic sources and sinks and through cell faces of the simulated water budget for a selected group of cells surrounding each well were analyzed during the sensitivity simulations to (1) compare changes in the size and shape of the zones of transport, (2) determine the sources and relative amounts of water being diverted by each well during each simulation, and (3) explain the behavior and uncertainty in estimating zones of transport when using a numerical ground-water flow model such as the Portland Basin model.

\section{Zone of Transport Analyses for Individual Wells}

In the following sections, results for each well are discussed with regard to the factors from table 2 that affect the size and shape of the area that is enclosed by the projection of a zone of transport onto a horizontal plane. These results are summarized in figures and tables.

\section{Town of Battle Ground Well 1}

The town of Battle Ground is located in the northeastern part of the study area near the foothills of the Cascade Range in north central Clark County (fig. 1). The town's municipal water system consists of four wells at two sites. Well number 1 (BG-1) discharges at an average rate of approximately 240 gallons per minute $\left(0.53 \mathrm{ft}^{3} / \mathrm{s}\right)$. Well BG-1 and another well at this site supply about two-thirds of the water that is used by the town of Battle Ground.

\section{Local Hydrogeologic Setting}

Well BG-1 discharges from the Troutdale gravel aquifer, the water-table aquifer, which was simulated by the two uppermost layers in the Portland Basin model. The aquifer is approximately $80 \mathrm{ft}$ thick at this site and overlies about $430 \mathrm{ft}$ of undifferentiated finegrained deposits, which were simulated by layers 3 to 7. Older rocks underlie these deposits and were simulated by layer 8 . Older rocks protrude upward to form an isolated outcrop (inlier) east of the well (row 28, column 37), and were simulated in all eight layers. Well BG-1 is located in row 27, column 35 of the Portland Basin model grid (fig. 5). 

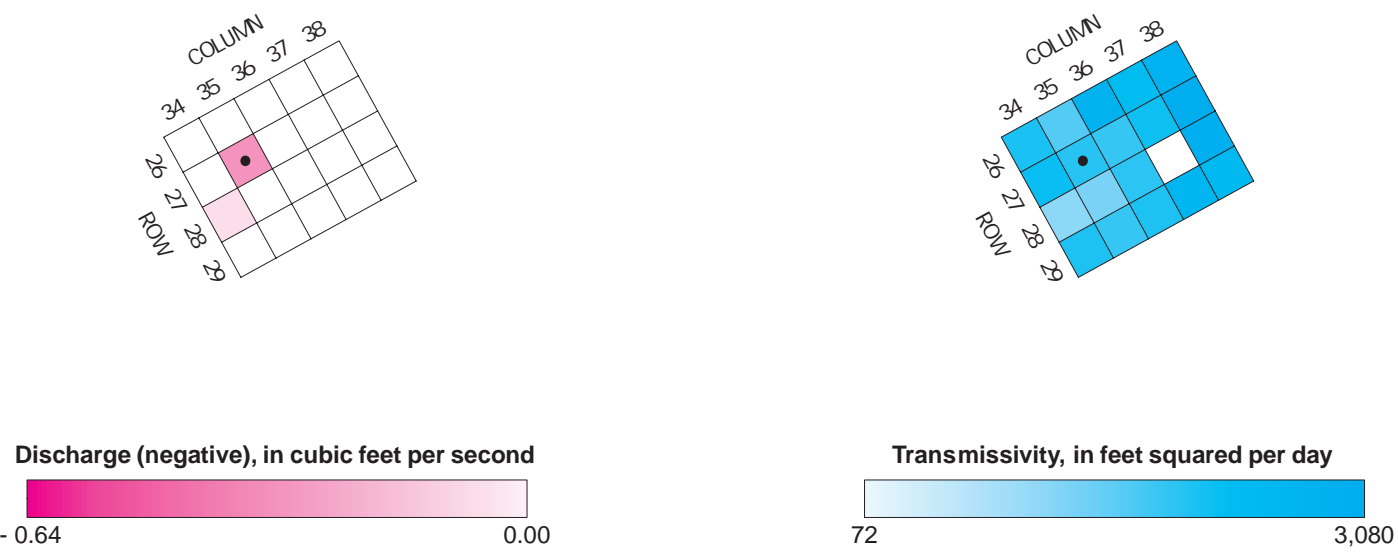

RECHARGE

POROSITY

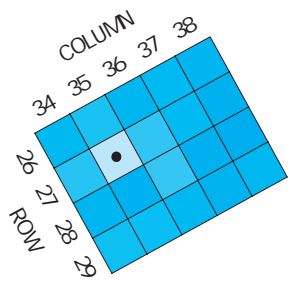

KILOMETERS

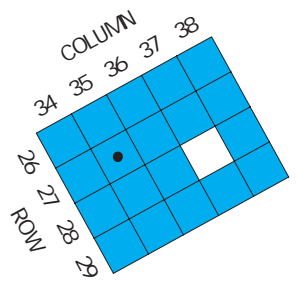

Recharge (positive), in cubic feet per second
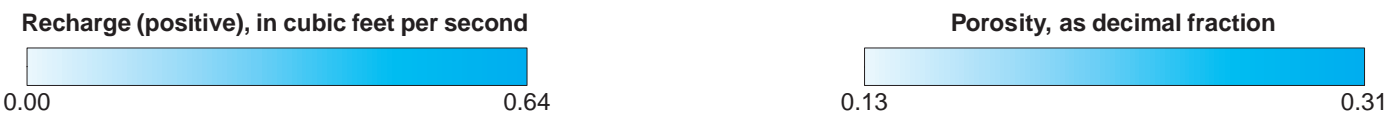

RIVER AND STREAM LEAKAGE
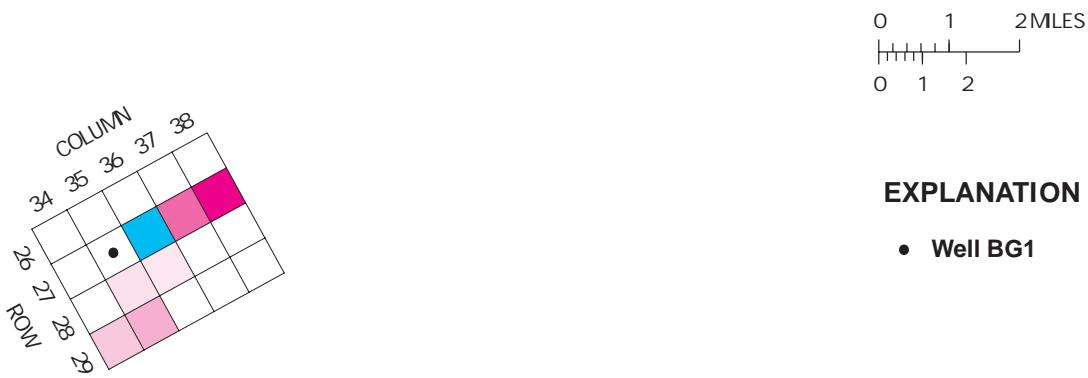

EXPLANATION

- Well BG1

Discharge (negative) or recharge (positive), in cubic feet per second

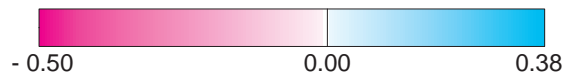

Figure 5. Simulated baseline conditions in layers 1 and 2, near well BG-1. (Source: Morgan and McFarland, 1996.) 
The simulated distributions of well discharge, recharge, and stream leakage in layers 1 and 2 of the Portland Basin model for a selected group of 20 cells in each layer surrounding well BG-1 are shown in figure 5. Well discharge for the individual cells where wells exist ranges from 0.14 to $0.64 \mathrm{ft}^{3} / \mathrm{s}$. Areal recharge in the selected cells ranges from 0.13 to $0.64 \mathrm{ft}^{3} / \mathrm{s}$, and represents recharge by infiltration of precipitation and from drywells into the ground-water system. Simulated stream leakage to and from Weaver Creek, a tributary of Salmon Creek, ranges from -0.50 to $0.38 \mathrm{ft}^{3} / \mathrm{s}$. Induced recharge from Weaver Creek has the potential to alter the quality of the water discharging from well BG-1 if the quality of water in the stream is different from the quality of the ground water in the vicinity of the well.

The local simulated transmissivity in the Troutdale gravel aquifer ranges from 1,170 to $3,080 \mathrm{ft}^{2} / \mathrm{d}$ (feet squared per day) (fig. 5). Transmissivity in the older rocks, which crop out at the surface, is as much as an order of magnitude lower, approximately $72 \mathrm{ft}^{2} / \mathrm{d}$, than that of the Troutdale gravel aquifer in the vicinity of well BG-1. In addition to their lower transmissivity, older rocks have lower porosity than the Troutdale gravel aquifer.

\section{Zones of Transport and Simulated Water Budget for the Baseline Simulation}

The zones of transport for well BG-1 were delineated by tracking particles along pathlines in the reverse direction of ground-water flow, starting from the two cells in layers 1 and 2 at row 27, column 35 . The reverse-direction pathlines of these particles were to the east in the upgradient direction, approximately perpendicular to lines of equal simulated hydraulic head in the Troutdale gravel aquifer and older rocks (fig. 6). The zone of transport for times of travel of 1 to 5 years or greater intercepted cells containing reaches of Weaver Creek.

Particle pathlines indicated that nearly all of the water that discharges from well BG-1 had recharged the Troutdale gravel aquifer within the past 20 years. Analysis of the pathlines also suggests that the particles follow pathlines that originate from recharge areas east of the well toward Weaver Creek.

The simulated water budget for the selected group of cells is listed in table 4 . Recharge from precipitation and dry wells supplied 75 percent of the total inflow in the baseline simulation (recharge was derived predominantly from precipitation), ground water flowing into this group of cells from surrounding cells in layers 1 and 2 (inflow, side faces) provided 22 percent, and induced infiltration from Weaver Creek (inflow, streams) contributed 3 percent.

Simulated discharge of ground water from this group of cells to adjacent cells in layers 1 and 2 (outflow, side faces) accounted for 52 percent of the total outflow, discharge to underlying cells in layer 3 (outflow, bottom face) accounted for 32 percent, ground-water discharge to Weaver Creek (outflow, streams) accounted for 9 percent, and discharge from wells (outflow, wells) accounted for 6 percent. (Percentages given in this report might not total 100 because of rounding.)

The size and shape of the zones of transport (fig. 6) were influenced by several factors. The recharge distribution was not an important factor in shaping the zones of transport because recharge from precipitation and from drywells within the selected group of cells varies little. The magnitude of recharge, however, affects the extent of each zone. Recharge from induced infiltration in one stream cell adjacent to the cell containing well BG-1 provided a significant source of water to the well and, thereby, influenced the shape of the zones of transport (fig. 6). Without this source of water, the zones would extend farther from the well, because the only other source of water (captured discharge) must provide an amount of recharge that balances the amount of water being discharged from well BG-1. The older-rocks inlier, with its lower permeability and porosity, affected particle velocity, which was one reason that the zones of transport for the longer time period do not extend farther east; that is, the transmissivity distribution affected the shape and extent of the zones. Figure 6 provides an illustration of the ways in which local distributions of transmissivity, porosity, recharge, and induced stream infiltration can affect the size and shape of zones of transport.

\section{Zones of Transport and Simulated Water Budget for the Increased-Discharge Simulation}

Increasing the discharge rate of well BG-1 affected the size and shape of the zones of transport, as well as the simulated ground-water levels, hydraulic gradient, and water budget, in the selected group of cells surrounding well BG-1. The increased discharge rate of well BG-1 caused the flow pattern of ground water, and hence particle pathlines, to change from the baseline simulation: particles delineating the zones of transport followed pathlines that originated farther from well BG-1, expanding the zones (figs. 6 and 7). 


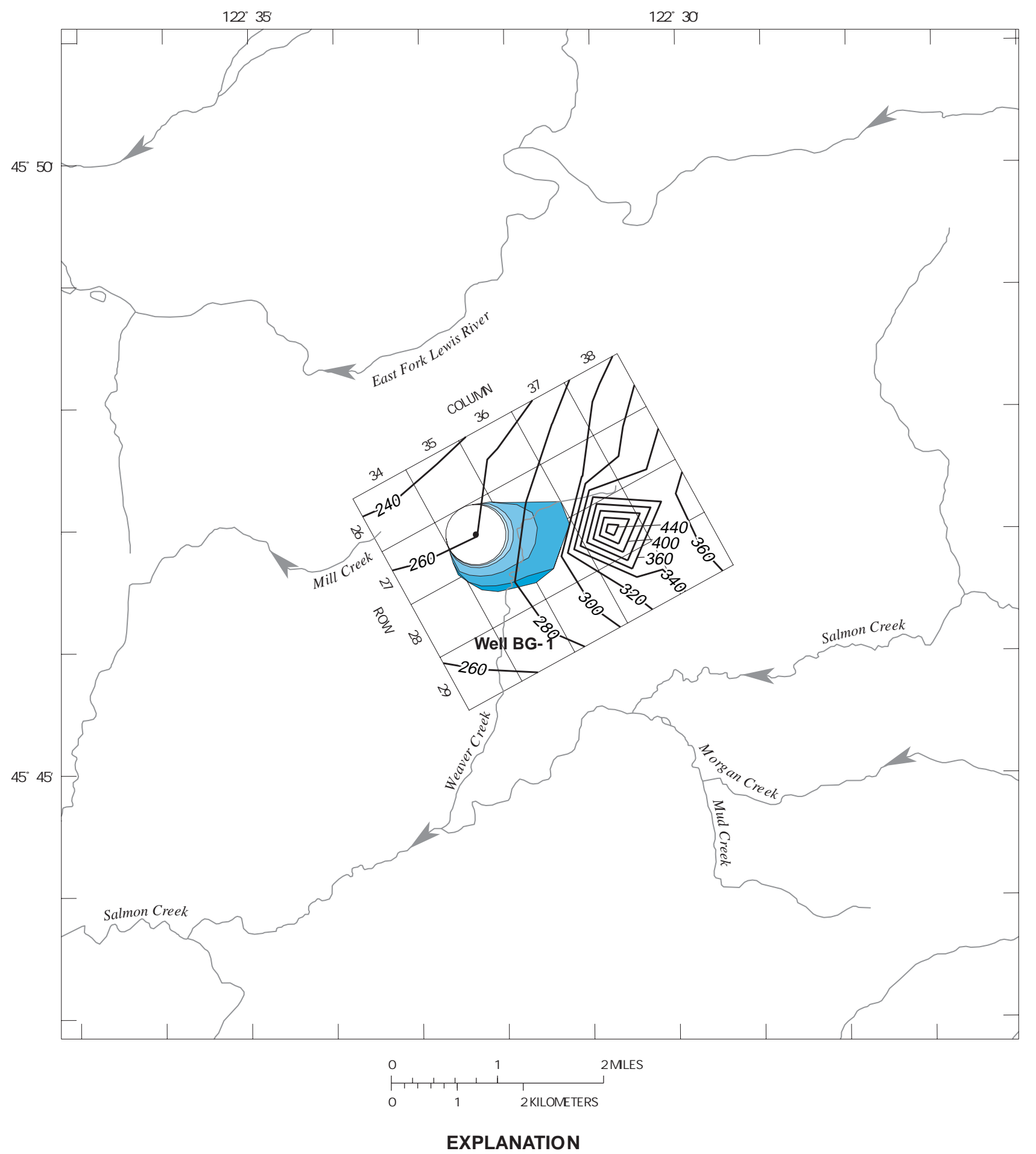

Zones of transport-value indicates time of travel in years.
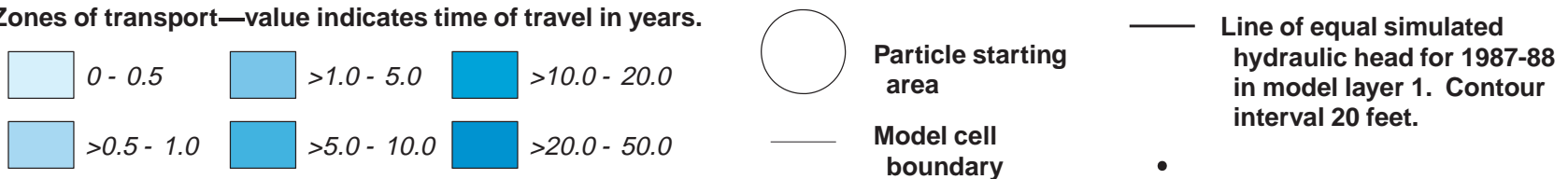

Figure 6. Projected zones of transport for well BG-1, under baseline conditions (>, greater than; <, less than; =, equal to). The direction of streamflow in Weaver Creek is from east to west. 
Table 4. Simulated water budget in a selected group of cells in layers 1 and 2 surrounding well BG-1, under different hydrologic conditions

\begin{tabular}{|c|c|c|c|c|c|c|}
\hline \multirow{2}{*}{\multicolumn{2}{|c|}{$\begin{array}{c}\text { Hydrologic source } \\
\text { or sink } \\
\text { or cell face } \\
\end{array}$}} & \multirow{2}{*}{$\begin{array}{l}\text { Baseline } \\
\text { flow } \\
\text { rate }^{1}\end{array}$} & \multirow{2}{*}{$\begin{array}{c}\text { Increased-discharge } \\
\text { Percent change }^{2} \\
\end{array}$} & \multirow{2}{*}{\begin{tabular}{|c|} 
No-interference \\
Percent change $^{2}$ \\
\end{tabular}} & \multirow{2}{*}{$\begin{array}{c}\text { Increased-conductivity } \\
\text { Percent change }^{2} \\
\end{array}$} & \multirow{2}{*}{$\begin{array}{c}\text { Decreased-conductivity } \\
\text { Percent change }^{2} \\
\end{array}$} \\
\hline & & & & & & \\
\hline \multirow{8}{*}{$\begin{array}{l}\frac{z}{0} \\
\underline{\underline{t}} \\
\underline{\underline{z}}\end{array}$} & Recharge & 9.99 & 0.0 & 0.0 & 0.0 & 0.0 \\
\hline & Drains & 0 & 0 & 0 & 0 & 0 \\
\hline & Rivers & 0 & 0 & 0 & 0 & 0 \\
\hline & Streams & .38 & 10.6 & -10.6 & -76.3 & -92.1 \\
\hline & Side faces & 2.90 & .7 & .3 & -1.0 & 5.5 \\
\hline & Top face & 0 & 0 & 0 & 0 & 0 \\
\hline & Bottom face & 0 & 0 & 0 & 0 & 0 \\
\hline & Total or net & 13.3 & $\begin{array}{lll} & \\
& .5 & \\
& \end{array}$ & $\begin{array}{rr}-.2 \\
\\
\end{array}$ & $\begin{array}{lll} & \\
& -2.4 & \\
\end{array}$ & $\begin{array}{llll} & -1.4 & & \\
\end{array}$ \\
\hline \multirow{11}{*}{$\frac{3}{\frac{3}{E}}$} & Recharge & 0 & 0 & 0 & 0 & 0 \\
\hline & Drains & 0 & 0 & 0 & 0 & 0 \\
\hline & Rivers & 0 & 0 & 0 & 0 & 0 \\
\hline & Streams & 1.23 & -6.5 & 14.6 & -92.7 & 131.7 \\
\hline & Wells & .77 & 35.1 & -29.9 & 0 & 0 \\
\hline & Side faces & 6.95 & -1.0 & 1.2 & 3.9 & -12.1 \\
\hline & Top face & 0 & 0 & 0 & 0 & 0 \\
\hline & Bottom face & 4.32 & -1.4 & -1.6 & 12.5 & -22.7 \\
\hline & Total or net & 13.3 & .5 & -.2 & -2.5 & -1.5 \\
\hline & Area $^{3}$ & 672 & 11.0 & -1.7 & 25.4 & 16.2 \\
\hline & Hydraulic head ${ }^{4}$ & --- & -.7 & 1.3 & -14.0 & 13.2 \\
\hline & $\begin{array}{l}1 \text { The flow rate for ba } \\
2 \text { Percent change whe } \\
3 \text { Value of the area en } \\
4 \text { values for the remai } \\
4 \text { Average change of }\end{array}$ & $\begin{array}{l}\text { line simulatic } \\
\text { compared to } \\
\text { osed by the } z \\
\text { ng simulation } \\
\text { draulic head }\end{array}$ & $\begin{array}{l}\text { n, inflow to and outflow fro } \\
\text { aseline simulation. } \\
\text { nes of transport ( } 20 \text { year t } \\
\text { s are the percent change in } \\
\text { rom baseline conditions (ir }\end{array}$ & $\begin{array}{l}m \text { the set of model cel } \\
\text { ne of travel) from tabl } \\
\text { cumulative area taken } \\
\text { feet) for the selected } g\end{array}$ & $\begin{array}{l}\text { s (in cubic feet per second). } \\
5 \text { for baseline simulation (in } \\
\text { rom table } 5 \text {. } \\
\text { roup of cells. }\end{array}$ & quare feet times $10^{4}$ ), \\
\hline
\end{tabular}

The total area enclosed by the zones of transport of well BG-1 increased by 11 percent from the baseline simulation (table 5). This expansion in area was accompanied by a decline of simulated ground-water levels and an increase of approximately 11 percent in recharge from induced infiltration from Weaver Creek in the selected group of cells (table 4 ). Simulated ground-water levels in the selected group of cells declined by a maximum of $4 \mathrm{ft}$ (in the cell containing well BG-1) and a minimum of 0.1 foot (in the cell at row 29, column 38). In addition, the general decline in ground-water levels reduced ground-water discharge to other stream cells, thereby reducing streamflow in Weaver Creek. After a new equilibrium was reached, the increase in the discharge to well BG- 1 of $0.25 \mathrm{ft}^{3} / \mathrm{s}$ was offset by (1) reductions in the discharge to the gaining reaches of Weaver Creek $\left(0.08 \mathrm{ft}^{3} / \mathrm{s}\right)$ and through the side and bottom faces of the group of cells $\left(0.13 \mathrm{ft}^{3} / \mathrm{s}\right)$ and (2) increases in the infiltration from the losing reach of Weaver Creek $\left(0.04 \mathrm{ft}^{3} / \mathrm{s}\right)$ and inflow through the side faces of the group of cells $\left(0.02 \mathrm{ft}^{3} / \mathrm{s}\right)$.

\section{Zones of Transport and Simulated Water Budget for the No-Interference Simulation}

Eliminating discharge from other wells in the Portland Basin model had little effect on the zones of transport for well BG-1. The total area enclosed by the zones of transport decreased by less than 2 percent (fig. 7 and table 5). Simulated ground-water levels in the selected group of cells increased by a minimum of $0.5 \mathrm{ft}$ (in the cell at row 27, column 38) and a maximum of $4 \mathrm{ft}$ (in the cell at row 28, column 34). 

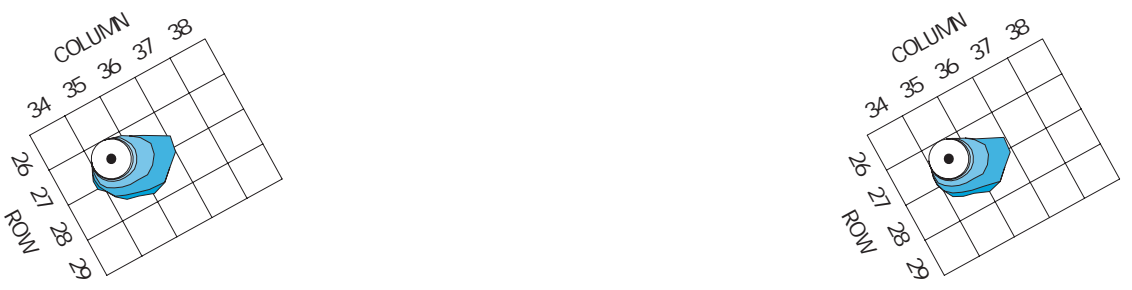

INCREASED POROSITY

\section{DECREASED POROSITY}

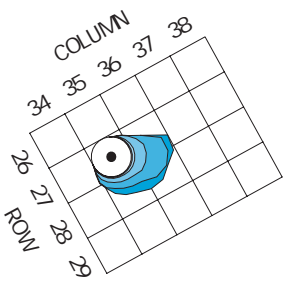

KILOMETERS

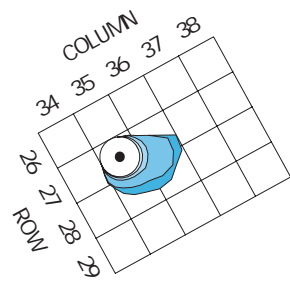

INCREASED CONDUCTIVITY

DECREASED CONDUCTIVITY
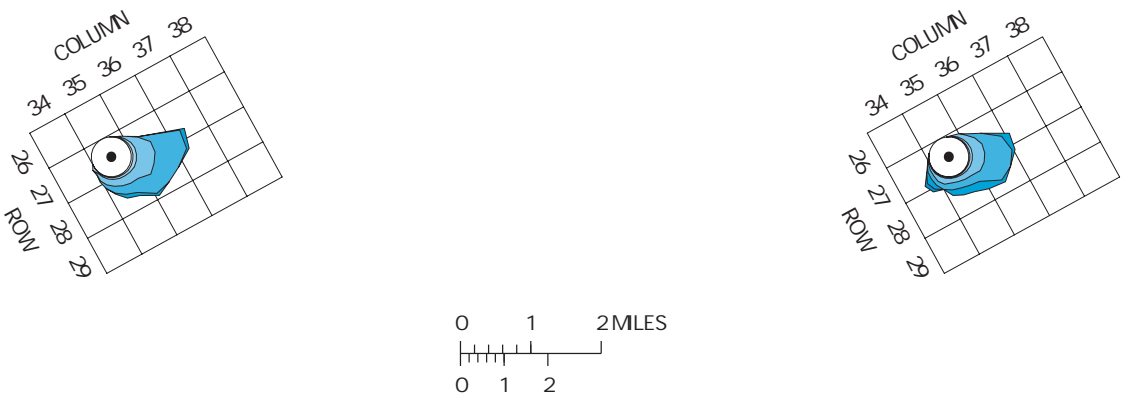

\section{EXPLANATION}

Zones of transport-value indicates time of travel in years.

$\square=0.5 \square>1.0-5.0 \square>10.0-20.0$
$\square>0.5-1.0 \square>5.0-10.0 \square>20.0-50.0$

Particle starting area

Model cell boundary

- Well BG-1

Figure 7. Projected zones of transport for well BG-1, under different hydrologic conditions (>, greater than; $<$, less than; =, equal to). 
Table 5. Areas of projected zones of transport from simulations for well BG-1

$[<$, less than]

\begin{tabular}{|c|c|c|c|c|c|c|c|c|c|c|c|c|c|c|}
\hline \multirow[b]{3}{*}{$\begin{array}{c}\text { Time } \\
\text { (years) }\end{array}$} & \multicolumn{2}{|c|}{ Baseline } & \multicolumn{2}{|c|}{ Increased-discharge } & \multicolumn{2}{|c|}{ No-Interference } & \multicolumn{2}{|c|}{ Increased-porosity } & \multicolumn{2}{|c|}{ Decreased-porosity } & \multicolumn{2}{|c|}{ Increased-conductivity } & \multicolumn{2}{|c|}{ Decreased-conductivity } \\
\hline & & & Perc & nt change & Perc & nt change & Percen & tt change & Percen & nt change & Perce & nt change & Perc & ent change \\
\hline & Area $^{1}$ & $\begin{array}{c}\text { Cumulative } \\
\text { area }^{2}\end{array}$ & Area $^{3}$ & $\begin{array}{l}\text { Cumulative } \\
\text { area }^{4}\end{array}$ & Area $^{3}$ & $\begin{array}{l}\text { Cumulative } \\
\text { area }^{4}\end{array}$ & Area $^{3}$ & $\begin{array}{c}\text { Cumulative } \\
\text { area }^{4}\end{array}$ & Area $^{3}$ & $\begin{array}{c}\text { Cumulative } \\
\text { area }^{4}\end{array}$ & Area $^{3}$ & $\begin{array}{l}\text { Cumulative } \\
\text { area }^{4}\end{array}$ & Area $^{3}$ & $\begin{array}{c}\text { Cumulative } \\
\text { area }^{4}\end{array}$ \\
\hline 0.5 & 14 & 228 & 20.6 & 1.3 & -7.8 & -0.5 & -29.6 & -1.9 & 69.9 & 4.8 & 8.2 & 0.5 & -21.3 & -1.3 \\
\hline 1 & 30 & 258 & 19.5 & 3.4 & -8.3 & -1.4 & -29.1 & -5.0 & 65.7 & 13.3 & 13.3 & 2.0 & -21.6 & -3.7 \\
\hline 5 & 149 & 407 & 19.4 & 9.3 & -6.8 & -3.4 & -28.9 & -13.7 & 66.2 & 34.0 & 19.9 & 8.5 & -16.1 & -8.2 \\
\hline 10 & 228 & 635 & 14.4 & 11.1 & $<.1$ & -2.2 & -6.3 & -11.1 & -40.3 & 6.3 & 55.7 & 25.5 & 23.4 & 3.1 \\
\hline 20 & 37 & 672 & 8.6 & 11.0 & 6.5 & -1.7 & 190.5 & $<-.1$ & -100.0 & $<-.1$ & 23.7 & 25.4 & 216.0 & 14.8 \\
\hline 50 & --- & --- & ---5 & ---5 & $-{ }_{--}^{5}$ & ---5 & $-{ }_{--}^{5}$ & $-{ }_{--}^{5}$ & ---5 & $-{ }_{--}^{5}$ & --- 5 & $-{ }_{-} 5$ & --- & $16.2^{6}$ \\
\hline
\end{tabular}

1 The area of the projected zones of transport for each selected time of travel for the baseline simulation, (in square feet times $10^{-4}$ ).

2 Summation of areas for this and all previous time steps for the baseline simulation, including the starting area, (in square feet times $10^{-4}$ ).

3 Percent change in area is the area for a simulation minus the area for the baseline simulation divided by the area for the baseline simulation.

Percent change in cumulative area is the cumulative area of a simulation minus the area of the baseline simulation divided by the area of the baseline simulation

5 No particles remaining by this time, and, therefore, changes can not be computed or compared.

6 Percent change in total cumulative area is the cumulative area for a simulation minus the total area for the baseline simulation divided by the total area for the baseline simulation. 
This rise was accompanied by a reduction of 11 percent in recharge from induced infiltration from Weaver Creek (table 4). The general increase in water levels was accompanied by an increase in ground-water discharge to streams.

\section{Zones of Transport for the Increased-Porosity and Decreased-Porosity Simulations}

Under increased-porosity and decreasedporosity conditions, the size and shape of individual zones of transport delineated for well BG-1 changed significantly from those in the baseline simulation, although the total area enclosed by all zones of transport changed by less than 1 percent (fig. 7). Porosity, which is used in the particle tracking analyses but not in the ground-water flow model, in part determines particle velocity (and hence the time of travel). The flow paths of the water represented by particle pathlines remained unchanged, but the particle velocities changed due to changes in porosity. Simulated volumetric flow rates from and to hydrologic sources and sinks and through cell faces also remained unchanged (table 4). The areas of the individual zones of transport for times of travel less than 10 years were reduced for increased porosity values, because ground water moves to the well more slowly than under baseline conditions. The areas of the individual zones of transport for times of travel of less than 5 years were expanded for decreased porosity values, because ground water moves to the well more rapidly than under baseline conditions. The total area enclosed by all zones did not decrease significantly, because most of the ground water contributing to the well originated at the water table and entered the cell containing well BG-1 in less than 50 years.

\section{Zones of Transport and Simulated Water Budget for the Increased-Conductivity and Decreased-Conductivity Simulations}

Varying the horizontal hydraulic conductivity from the baseline simulation caused significant changes in the water budget and ground-water levels and gradients. The size and shape of the zones of transport delineated for well BG-1 were significantly influenced by the reduced hydraulic gradient and by changes in the simulated water budget under increased-conductivity conditions (fig. 7, table 4). Simulated water levels in the selected group of cells in layer 1 declined by an average of approximately $14 \mathrm{ft}$. Under increased-conductivity conditions, Weaver
Creek did not received ground-water discharge and was "dry" in the reach upstream of row 28 , column 38 , due to the decrease in water levels. Therefore, leakage from Weaver Creek was no longer available as a source of water to well BG-1. The expansion of the zones of transport for well BG-1 was caused because capture of discharge to Weaver Creek or inducement of recharge from the creek was no longer possible. Thus, the drawdown caused by the well extended to a greater area in order to capture discharge to other streams.

Under decreased-conductivity conditions, the size and shape of the zones of transport delineated for well BG-1 were also significantly influenced by changes in the simulated hydraulic gradient and by changes in the simulated water budget (fig. 7, table 4). Simulated water levels in the selected group of cells in layer 1 rose by an average of $13 \mathrm{ft}$. The maximum rise of $48 \mathrm{ft}$ occurred in the cell at row 28 , column 37 , the older-rocks inlier, producing a steeper hydraulic gradient in the older-rocks inlier than under baseline conditions. The hydraulic gradient lessened west of the older-rocks inlier in the Troutdale gravel aquifer. For times of travel of less than 5 years, the reduced gradient in the Troutdale gravel aquifer accounted for lower particle velocities and a decrease in the size of the zones of transport than under baseline conditions. Zones of transport for times of travel greater than 5 years expanded because velocities of particles closer to the older-rocks inlier were greater than under baseline conditions.

The expansion of some of the zones of transport for well BG-1 under decreased-conductivity conditions was accompanied by a change in the proportion of water from each source to well BG-1; more water was diverted to well BG-1 from capture of discharge to compensate for the reduction in induced infiltration from Weaver Creek (table 4). Owing to the higher water levels under decreased-conductivity conditions, the model simulated the greater discharge to Weaver Creek within the selected cells. With ground-water levels at their highest levels for any of the simulations, infiltration from Weaver Creek within the group of cells was only 8 percent of that under baseline conditions. Furthermore, a zone of transport for times of travel of between 20 and 50 years was delineated under decreased-conductivity conditions. Water represented by the particles used to delineate this zone originated at the water table southwest of well BG-1, indicating a change in the pattern of flow in the ground-water system from baseline conditions. 


\section{Summary of Simulation Scenarios for Well BG-1}

Under baseline conditions, the zones of transport to BG-1 extended laterally to the east and southeast, generally following the trend in the hydraulic gradient within the Troutdale gravel aquifer. The zones of transport for well BG-1 mainly encompassed times of travel of up to 10 years, although a small zone southeast of the well that contributes water between 10 and 20 years old. Results of the particle-tracking analysis from the baseline simulation indicated that nearly all of the water that discharged from well BG-1 recharged the Troutdale gravel aquifer within 20 years.

Uncertainty in the horizontal hydraulic conductivity of the Troutdale gravel aquifer contributed more to the uncertainty in delineating the zones of transport for well BG-1 than did uncertainty in other factors. Uncertainty in other factors, such as well discharge rate and porosity, had measurable effects on the zones of transport, but errors introduced through changes in these factors were less significant. Changing the horizontal hydraulic conductivity by multiplying by 0.8 and 1.2 altered the ground-water levels and hydraulic gradient in the vicinity of well BG-1; in fact, these alterations moved the flow model out of calibration, but were useful for estimating the effects of uncertainty in this factor.

Hydraulic conductivity values greater than baseline values caused reduced water levels and hydraulic gradients east of well BG-1. Zones of transport were 25 percent larger in this simulation than for the baseline simulation because less recharge was available from Weaver Creek. As a result, the cone-of-depression for well BG-1 to extended farther in order to capture discharge to or induce recharge from other streams. Weaver Creek received little baseflow in the simulation because water levels were reduced beneath its upstream reaches and therefore the creek was "dry" in reaches that supplied recharge under baseline conditions. Although this is not a realistic condition, it illustrates the effects of recharge from Weaver Creek on the baseline zones of transport.

Hydraulic conductivity values less than baseline values caused increased water levels and hydraulic gradients near well BG-1. Zones of transport were also larger (15 percent) in this simulation than the baseline simulation. In this case, however, Weaver Creek received 32 percent more ground-water discharge than under baseline conditions. The reduced hydraulic conductivity apparently caused a change in ground-water flow direction near BG-1 that extended the zones of transport to the south, where there had been no zones under baseline conditions. As above, this is not a realistic condition, but it does illustrate the importance of local ground-water flow direction and gradient in delineating the zones of transport.

\section{City of Vancouver Well 4.1}

The city of Vancouver is located in the southern part of Clark County, adjacent to the Columbia River (fig. 1). City of Vancouver Well No. $4.1(\mathrm{CV}-4.1)$ is part of well station 4, which is one of the principal water sources for the municipal system of the city of Vancouver. Well CV-4.1 discharges at approximately 3,700 gallons per minute $\left(8.2 \mathrm{ft}^{3} / \mathrm{s}\right)$ and supplies about one-half of the water used by the city of Vancouver.

\section{Local Hydrogeologic Setting}

Well CV-4.1 discharges from the unconsolidated sedimentary aquifer, the water-table aquifer, which was simulated by the uppermost model layer in the Portland Basin model. The water-table aquifer is approximately $70 \mathrm{ft}$ thick at this location and overlies the Troutdale gravel aquifer. The Troutdale gravel aquifer is approximately $150 \mathrm{ft}$ thick in the vicinity of well CV-4.1 and was simulated by layer 2 . The Troutdale gravel aquifer crops out at the land surface in five cells (about 1 mile northeast to east of well CV-4.1, along the bluffs that border the Columbia River), and in one cell about 1 mile due east of well CV-4.1. The undifferentiated fine-grained deposits, which underlie the Troutdale gravel aquifer, are approximately $1,400 \mathrm{ft}$ thick at the well site and were simulated by layers 3 through 7. The older rocks, which underlie these deposits, were simulated by layer 8 . City of Vancouver Well No. 4.1 is located in row 41, column 19 of the Portland Basin model grid (fig. 8).

The simulated local distributions of well discharge, recharge, and river and stream leakage in layer 1 of the Portland Basin model for a selected group of 66 cells surrounding well CV-4.1 are shown in figure 8 . Well discharge for the individual cells where wells exist ranges from 0.06 to $8.28 \mathrm{ft}^{3} / \mathrm{s}$. Areal recharge in the selected cells ranges from 0.0 to $0.73 \mathrm{ft}^{3} / \mathrm{s}$ (fig. 8). Positive values in figure 8 indicate recharge by infiltration of precipitation and from drywells into the ground-water system. The zero values along the northern bank of the Columbia River are in industrial and urban areas with a high percentage of impervious surfaces that restrict recharge (Snyder and others, 1994). The northern bank of the Columbia River is shown in figure 9. 
WELL DISCHARGE

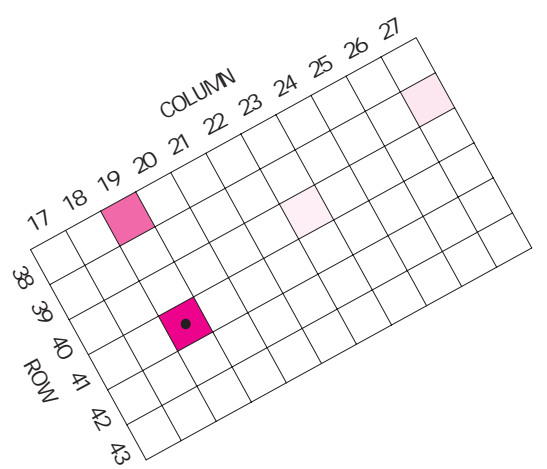

Discharge (negative), in cubic feet per second

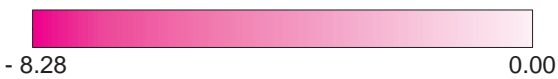

RECHARGE

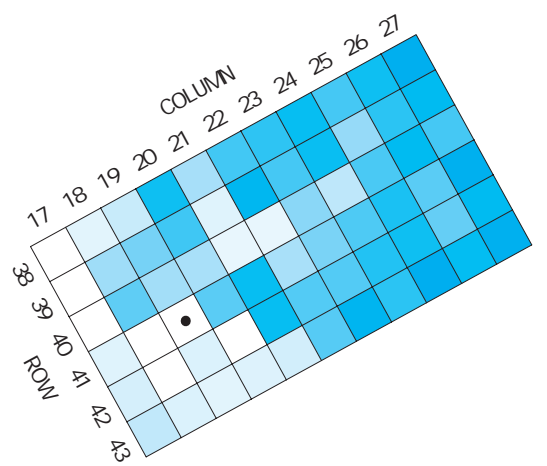

Recharge (positive), in cubic feet per second

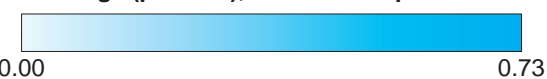

RIVER AND STREAM LEAKAGE

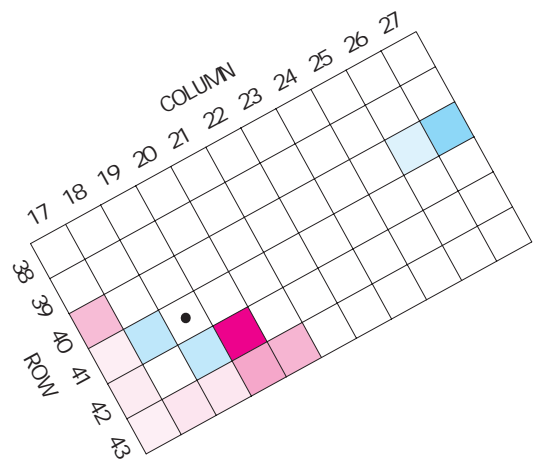

TRANSMISSIVITY
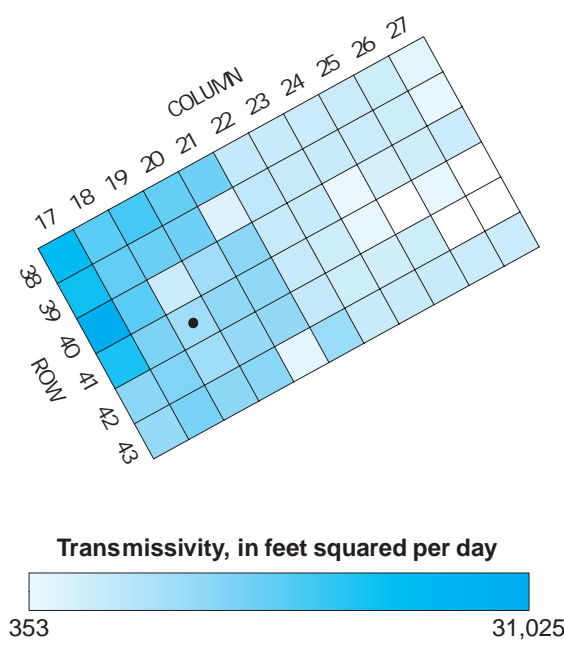

\section{POROSITY}
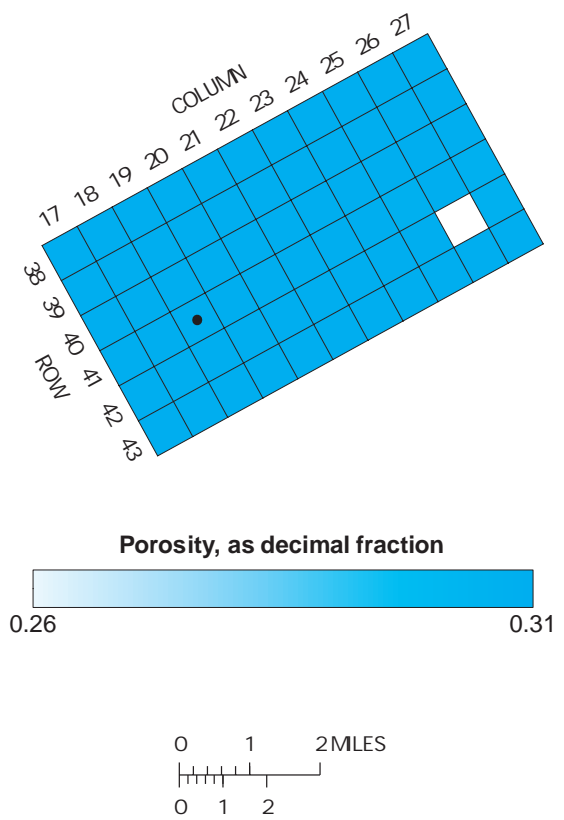

\section{EXPLANATION}

- Well CV4. 1

Discharge (negative) or recharge (positive), in cubic feet per second

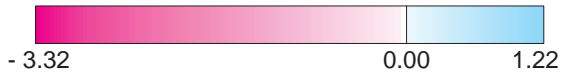

Figure 8. Simulated baseline conditions in layer 1, near well CV-4.1. (Source: Morgan and McFarland, 1996.) 


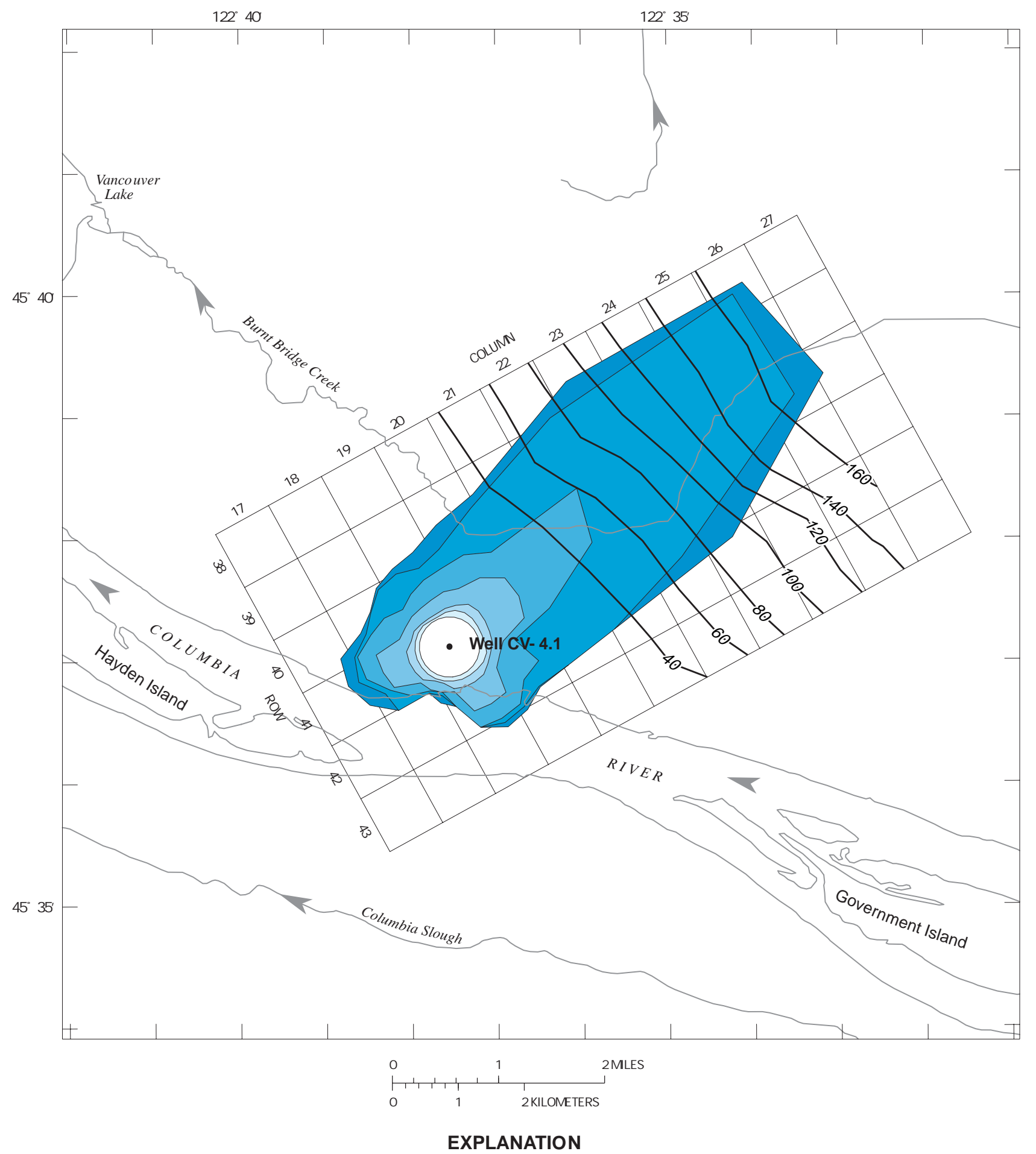

Zones of transport-value indicates time of travel in years.

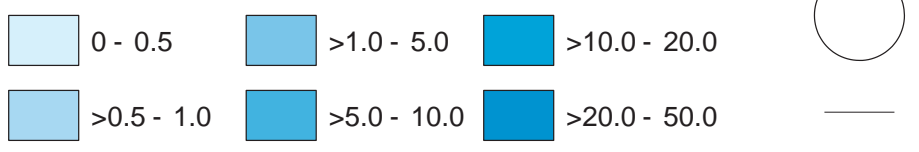

Particle starting area

Model cell boundary

Figure 9. Projected zones of transport for well CV-4.1, under baseline conditions (>, greater than; <, less than; =, equal to). The direction of streamflow in the Columbia River and Burnt Bridge Creek is from east to west. 
Simulated river leakage ranges from -3.3 to $0.61 \mathrm{ft}^{3} / \mathrm{s}$ for cells representing the Columbia River (fig. 8). Negative values in figure 8 indicate discharge to rivers from the ground-water system, and positive values indicate recharge into the ground-water system from rivers. The model simulated recharge from induced infiltration from the Columbia River in three cells adjacent to well CV-4.1; in nine other river cells, the model simulated ground-water discharge to the Columbia River. Induced recharge from the Columbia River has the potential to alter the quality of the water discharging from well CV-4.1 if the quality of water in the river is different from the quality of the ground water in the vicinity of the well. Simulated stream leakage ranges from 0.0 to $0.23 \mathrm{ft}^{3} / \mathrm{s}$ for cells representing Burnt Bridge Creek (fig. 8); the stream channel for Burnt Bridge Creek is shown in figure 9. The Portland Basin model simulated recharge from induced infiltration from Burnt Bridge Creek in only one stream cell (row 40, column 26); no streamflow was simulated west of this one cell in Burnt Bridge Creek because the model did not simulate discharge to Burnt Bridge Creek or flow in the channel other than in the cell at row 40, column 26 . No water can infiltrate from the stream to well CV-4.1 to provide additional recharge because Burnt Bridge Creek becomes dry as it nears this well.

The local distribution of simulated transmissivity of layer 1 ranges from about 350 to $31,000 \mathrm{ft}^{2} / \mathrm{d}$ across the selected group of cells (fig. 8). The variation in transmissivity relates to changes in thickness and hydraulic conductivity within the unconsolidated sedimentary aquifer and within the Troutdale gravel aquifer. The local transmissivity of cells representing the unconsolidated sedimentary aquifer ranges from about 1,250 to $31,000 \mathrm{ft}^{2} / \mathrm{d}$, and the transmissivity of cells representing the Troutdale gravel aquifer ranges from about 350 to $2,400 \mathrm{ft}^{2} / \mathrm{d}$ in the vicinity of well CV-4.1. In addition to having lower transmissivity, most cells representing the Troutdale gravel aquifer have simulated porosity values lower than those in cells representing the unconsolidated sedimentary aquifer.

\section{Zones of Transport and Simulated Water Budget for the Baseline Simulation}

The zones of transport for well CV-4.1 were delineated by tracking particles along pathlines in the reverse direction of ground-water flow, starting from one cell in layer 1 at row 41, column 19. Most of the reverse-direction pathlines of these particles were to the northeast in the upgradient direction, approximately perpendicular to lines of equal simulated hydraulic head in unconsolidated sedimentary and Troutdale gravel aquifers in layer 1. (Lines of equal simulated hydraulic head for layer 1 are shown in fig. 9.) Some particle pathlines were toward cells representing simulated reaches of the Columbia River. The zones of transport for well CV-4.1 intercepted these cells, indicating leakage from the river as a source of water to the well.

Particle pathlines indicated that most of the water that discharges from well CV-4.1 had recharged the unconsolidated sedimentary aquifer within 50 years. Analysis of the pathlines also suggests that well CV-4.1 induces recharge from the Columbia River and captures some ground water older than 50 years that would otherwise discharge to the Columbia River.

The simulated water budget for the selected group of cells is listed in table 6 . Recharge from precipitation and drywells supplied 52 percent of the total inflow in the baseline simulation (recharge was derived predominantly from precipitation), ground water flowing into this group of cells from surrounding cells within layer 1 (inflow, side faces) provided 22 percent, ground water flowing into this group of cells from underlying cells within layer 2 (inflow, bottom face) also provided 22 percent, induced infiltration from the Columbia River (inflow, rivers) contributed 4 percent, and induced infiltration from Burnt Bridge Creek (inflow, streams) contributed less than 1 percent. The amount of recharge from ground water into the selected group of cells was equally divided among adjacent and underlying cells.

Simulated discharge from wells (outflow, wells) accounted for 44 percent of the total outflow, discharge to underlying cells in layer 2 (outflow, bottom face) accounted for 24 percent, ground-water discharge to the Columbia River (outflow, rivers) accounted for 22 percent, discharge of ground water from this group of cells to adjacent cells in layer 1 (outflow, side faces) accounted for 12 percent within the group of selected cells. No ground-water discharge was simulated to Burnt Bridge Creek (outflow, streams).

The size and shape of the zones of transport (figure 9) were influenced by several factors that determined the direction and velocity of the particles used to delineate the zones. The shape of the zones was most influenced by hydraulic gradient in the prox- 
Table 6. Simulated water budget in a selected group of cells in layer 1 surrounding well CV-4.1, under different hydrologic conditions

\begin{tabular}{|c|c|c|c|c|c|c|}
\hline \multirow{2}{*}{\multicolumn{2}{|c|}{$\begin{array}{l}\text { Hydrologic source } \\
\text { or sink } \\
\text { or cell face }\end{array}$}} & \multirow{2}{*}{$\begin{array}{l}\text { Baseline } \\
\text { flow } \\
\text { rate } 1\end{array}$} & \multirow{2}{*}{$\begin{array}{c}\text { Increased-discharge } \\
\text { Percent change }^{2}\end{array}$} & \multirow{2}{*}{$\begin{array}{l}\text { No-interference } \\
\text { Percent change }^{2}\end{array}$} & \multirow{2}{*}{$\begin{array}{c}\text { Increased-conductivity } \\
\text { Percent change }^{2}\end{array}$} & \multirow{2}{*}{$\frac{\text { Decreased-conductivity }}{\text { Percent change }^{2}}$} \\
\hline & & & & & & \\
\hline \multirow{8}{*}{ 吕 } & Recharge & 17.4 & 0.0 & 0.0 & 0.0 & 0.0 \\
\hline & Drains & 0 & 0 & 0 & 0 & 0 \\
\hline & Rivers & 1.2 & 200.8 & -100.0 & -34.2 & 31.7 \\
\hline & Streams & .2 & -17.4 & 2,900 & -100.0 & $1,156.6$ \\
\hline & Side faces & 7.4 & 2.2 & -31.1 & 7.8 & -22.8 \\
\hline & Top face & 0 & 0 & 0 & 0 & 0 \\
\hline & Bottom face & 7.5 & 16.9 & 59.6 & 12.3 & -7.6 \\
\hline & Total or net & 33.7 & 11.4 & 22.5 & 2.5 & 2.3 \\
\hline \multirow{11}{*}{$\frac{3}{\frac{3}{E}}$} & Recharge & 0 & 0 & 0 & 0 & 0 \\
\hline & Drains & 0 & 0 & 0 & 0 & 0 \\
\hline & Rivers & 7.3 & -14.5 & 100.7 & 9.7 & -8.3 \\
\hline & Streams & 0 & 0 & $.32^{5}$ & 0 & 0 \\
\hline & Wells & 14.5 & 28.6 & -42.9 & 0 & 0 \\
\hline & Side faces & 3.9 & -3.6 & 69.4 & 9.6 & -8.3 \\
\hline & Top face & 0 & 0 & 0 & 0 & 0 \\
\hline & Bottom face & 8.0 & 11.2 & 42.5 & -3.0 & 21.4 \\
\hline & Total or net & 33.7 & 11.4 & 22.5 & 2.5 & 2.3 \\
\hline & Area $^{3}$ & 7,528 & 11.5 & -18.9 & 2.5 & -6.1 \\
\hline & Hydraulic head ${ }^{4}$ & --- & -1 & 22 & -5 & 16 \\
\hline \multicolumn{7}{|c|}{$\begin{array}{l}1 \text { The flow rate for baseline simulation, inflow to and outflow from the set of model cells (in cubic feet per second). } \\
2 \text { Percent change when compared to baseline simulation. } \\
3 \text { Value of the area enclosed by all zones of transport ( } 50 \text { year time of travel) from table } 7 \text { for baseline simulation (in square feet times } 10^{4} \text { ), } \\
\text { values for the remaining simulations are the percent change in cumulative area taken from table } 7 \text {. } \\
5 \text { Average change of hydraulic head from baseline conditions (in feet) for the selected group of cells. } \\
5 \text { The flow rate of discharge to stream which was simulated only under no-interference conditions (in cubic feet per second). }\end{array}$} \\
\hline
\end{tabular}

imity of well CV-4.1. North of well CV-4.1, the zones extended to the northeast along the axis of the hydraulic gradient. South of well CV-4.1, the zones extended toward the Columbia River, because the cone of depression caused by pumping of the well reversed the natural gradient. The extent of each zone was also influenced by induced infiltration from the Columbia River, which provided a significant source of water to the well.

\section{Zones of Transport and Simulated Water Budget for the Increased-Discharge Simulation}

Increasing the discharge rate of well CV-4.1 affected the size and shape of the zones of transport as well as the simulated ground-water levels, hydraulic gradient, and water budget in the selected group of cells surrounding well CV-4.1. The increased dis- charge rate of well CV-4.1 caused the flow pattern of ground water, and hence particle pathlines, to change from the baseline simulation: particles delineating the zones of transport followed pathlines that originated farther from well CV-4.1, expanding the zones (fig. 10, table 7). The total area enclosed by the zones of transport of well CV-4.1 increased nearly 12 percent from the baseline simulation, with much of the expansion for times of travel of less than 20 years. North of the Columbia River, simulated ground-water levels in the selected group of cells declined by an average of less than 1 foot from baseline conditions with the maximum decline (approximately $7 \mathrm{ft}$ ) occurring in the cell containing well CV-4.1. Induced infiltration from Burnt Bridge Creek decreased approximately 17 percent under increased-discharge conditions, because streamflow declined in Burnt Bridge Creek. 

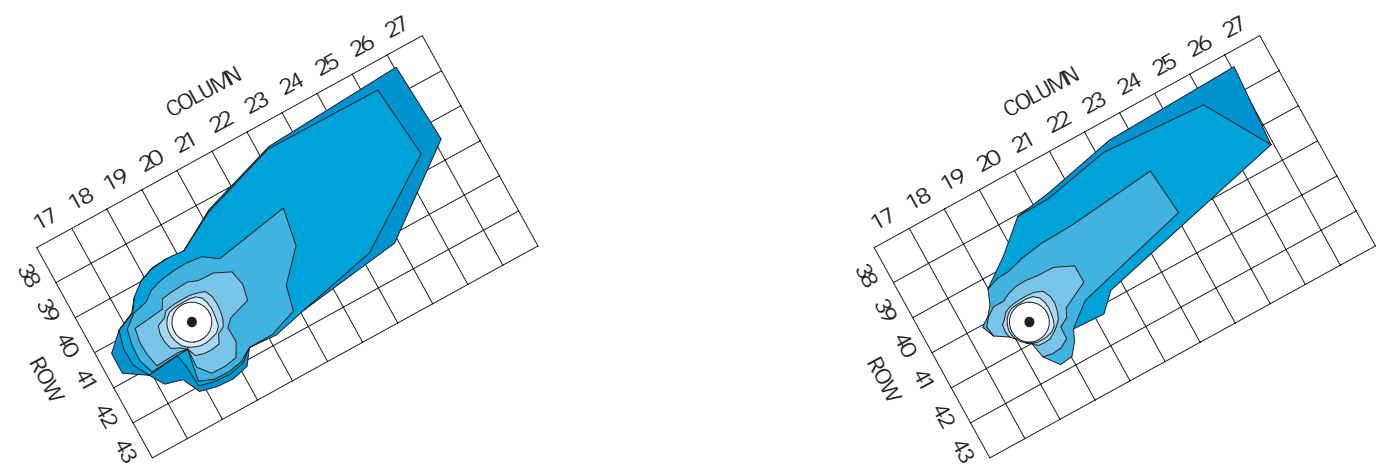

INCREASED POROSITY

DECREASED POROSITY
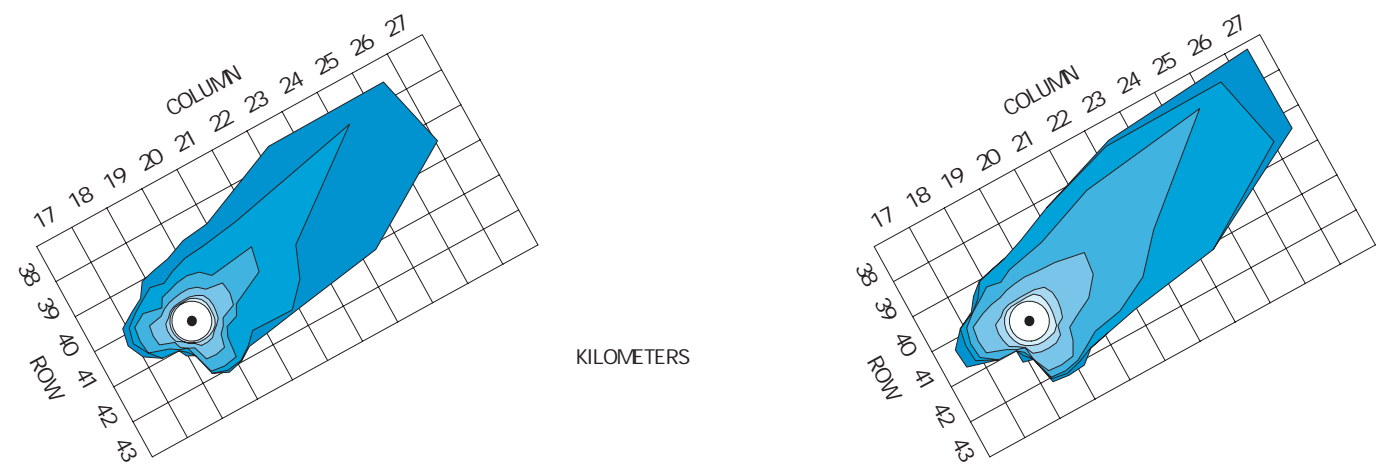

INCREASED CONDUCTIVITY

DECREASED CONDUCTIVITY

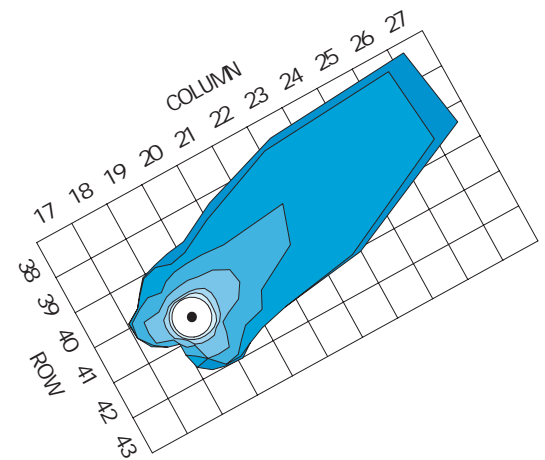

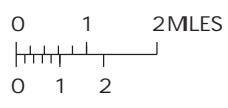

EXPLANATION

Zones of transport-value indicates time of travel in years.

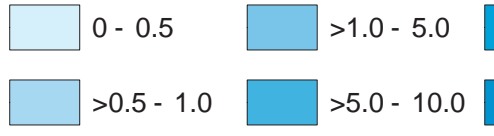

$>10.0-20.0$

$>20.0-50.0$

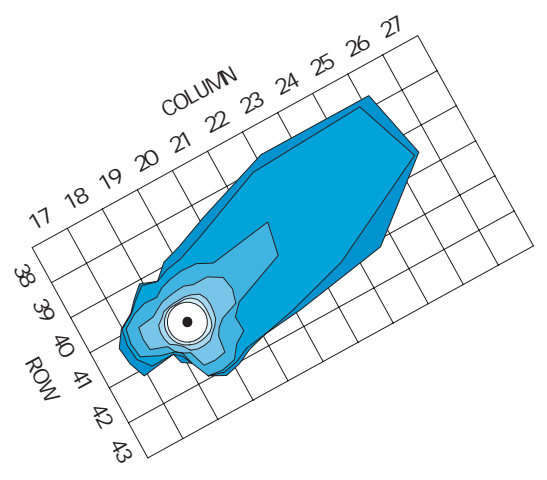

Particle starting area

Model cell boundary

- Well CV- 4.1

Figure 10. Projected zones of transport for well CV-4.1, under different simulated hydrologic conditions (>, greater than; <, less than; =, equal to). 
Table 7. Areas of projected zones of transport from different simulations for well CV-4.1

\begin{tabular}{|c|c|c|c|c|c|c|c|c|c|c|c|c|c|c|}
\hline \multirow[b]{3}{*}{$\begin{array}{c}\text { Time } \\
\text { (years) }\end{array}$} & \multicolumn{2}{|c|}{ Baseline } & \multicolumn{2}{|c|}{ Increased-discharge } & \multicolumn{2}{|c|}{ No-Interference } & \multicolumn{2}{|c|}{ Increased-porosity } & \multicolumn{2}{|c|}{ Decreased-porosity } & \multicolumn{2}{|c|}{ Increased-conductivity } & \multicolumn{2}{|c|}{ Decreased-conductivity } \\
\hline & & & Perc & ent change & Perc & nt change & Perce & nt change & Perce & nt change & Perc & ent change & Perc & ent change \\
\hline & Area $^{1}$ & $\begin{array}{c}\text { Cumulative } \\
\text { area }^{2}\end{array}$ & Area $^{3}$ & $\begin{array}{l}\text { Cumulative } \\
\text { area }^{4}\end{array}$ & Area $^{3}$ & $\begin{array}{l}\text { Cumulative } \\
\text { area }^{4}\end{array}$ & Area $^{3}$ & $\begin{array}{c}\text { Cumulative } \\
\text { area }^{4}\end{array}$ & Area $^{3}$ & $\begin{array}{c}\text { Cumulative } \\
\text { area }^{4}\end{array}$ & Area $^{3}$ & $\begin{array}{l}\text { Cumulative } \\
\text { area }^{4}\end{array}$ & Area $^{3}$ & $\begin{array}{l}\text { Cumulative } \\
\text { area }^{4}\end{array}$ \\
\hline 0.5 & 74 & 286 & 54.7 & 14.1 & -7.7 & -2.0 & -28.4 & -7.3 & 66.0 & 17.0 & -0.8 & -0.2 & 0.8 & 0.2 \\
\hline 1 & 112 & 398 & 56.0 & 25.8 & -15.3 & -5.7 & -38.7 & -16.1 & 72.3 & 32.5 & -2.3 & -.8 & 1.0 & .4 \\
\hline 5 & 481 & 879 & 47.1 & 37.4 & 3.0 & -1.0 & -29.5 & -23.4 & 79.2 & 58.0 & 2.3 & .9 & .4 & .4 \\
\hline 10 & 1,119 & 1,998 & 40.0 & 38.9 & 53.7 & 29.6 & -44.4 & -35.1 & 141.2 & 104.6 & 10.5 & 6.3 & -11.9 & -6.5 \\
\hline 20 & 4,275 & 6,273 & 4.2 & 15.2 & -34.1 & -13.8 & -50.3 & -45.5 & -22.8 & 17.8 & 6.8 & 6.7 & -3.6 & -4.5 \\
\hline 50 & 1,255 & 7,528 & -6.9 & 11.5 & -44.2 & -18.9 & 204.8 & -3.8 & -25.6 & 10.6 & -18.2 & 2.5 & -13.8 & -6.1 \\
\hline
\end{tabular}

1 The area of the projected zones of transport for each selected time of travel for the baseline simulation, (in square feet times $10^{-4}$ ).

2 Summation of areas for this and all previous time steps for the baseline simulation, including the starting area, (in square feet times $10^{-4}$ ).

3 Percent change in area is the area for a simulation minus the area for the baseline simulation divided by the area for the baseline simulation.

4 Percent change in cumulative area is the cumulative area of a simulation minus the area of the baseline simulation divided by the area of the baseline simulation. 
In cells representing the Columbia River, simulated ground-water levels remained relatively unchanged, declining an average of less than 0.1 foot. This decline was accompanied by a gain of approximately 200 percent in induced infiltration from the Columbia River (table 6), and the model simulated recharge from induced infiltration in one more river cell than under baseline conditions. The hydraulic gradient between the river and river cells increased from baseline conditions, thereby increasing induced infiltration and reducing ground-water discharge to the river. The expansion of the zones of transport for well CV-4.1 was accompanied by a change in the proportion of water from each source to well CV-4.1. After a new equilibrium was reached, the increase in the discharge to well CV-4.1 was offset by reductions in groundwater discharge to the Columbia River and increases in the infiltration from the losing reaches of the Columbia River.

\section{Zones of Transport and Simulated Water Budget for the No-Interference Simulation}

When discharge other than that of well CV-4.1 was excluded from the Portland Basin model, the total area enclosed by the zones of transport decreased by approximately 19 percent from baseline conditions (fig. 10 and table 7). The areas enclosed by the zones narrowed, because the hydraulic gradient increased north of well CV-4.1, extending the zones farther from the well. North of the Columbia River, simulated ground-water levels increased an average of $22 \mathrm{ft}$. The simulated ground-water level increased by approximately $3 \mathrm{ft}$ in the cell containing well CV-4.1. However, simulated ground-water levels in cells containing the Columbia River remained relatively unchanged, increasing by an average of less than 0.6 foot. This increase caused the elimination of induced infiltration from the Columbia River. The discharge rate of well CV-4.1 alone was insufficient to induce infiltration from the Columbia River. The model simulated no ground-water discharge to Burnt Bridge Creek in the selected group of cells under baseline conditions, but under no-interference conditions, the model simulated ground-water discharge to Burnt Bridge Creek in two stream cells (rows 39 and 40, column 26). Downstream of these two cells, the model simulated induced infiltration from Burnt Bridge Creek in six stream cells until streamflow was depleted. Eliminating discharge from other wells had a significant effect on the zones of transport for well CV-4.1 and the source of water to the well.

\section{Zones of Transport for the Increased-Porosity and Decreased-Porosity Simulations}

The size and shape of the zones of transport delineated for well CV-4.1 changed significantly from those in the baseline simulation under increasedporosity and decreased-porosity conditions (fig. 10, table 7). The areas of the zones of transport, except for times of travel of 20 to 50 years, were reduced under increased-porosity conditions because ground water moved to the well more slowly than under baseline conditions. The areas of all zones of transport, except for times of travel of greater than 10 years, were expanded under decreased-porosity conditions because ground water moved to the well more rapidly than under baseline conditions. The magnitude of the changes in the areas of the zones of transport (table 7) indicates that a significant amount of the ground water discharging from the well is captured discharge from the regional ground-water flow system that has not reached the well in less than 20 years.

\section{Zones of Transport and Simulated Water Budget for the Increased-Conductivity and Decreased-Conductivity Simulations}

Varying the horizontal hydraulic conductivity from the baseline simulation caused minor changes in the areas of the zones of transport delineated for well CV-4.1 and significant changes in the simulated water budget and ground-water levels (fig. 10, table 6). Under increased-conductivity conditions, the size and shape of the zones of transport were influenced by the reduced hydraulic gradient. In the selected group of cells, simulated water levels in non-river cells declined by an average of $5 \mathrm{ft}$; however, simulated water levels in river cells remained relatively unchanged, rising or declining by less than 0.1 foot. The well induced less infiltration from the Columbia River, and in one river cell the hydraulic gradient reversed from the baseline simulation. Under increasedconductivity conditions, leakage from Burnt Bridge Creek was no longer available as a source of water to well CV-4.1 because Burnt Bridge Creek did not receive ground-water discharge in its upstream reaches and was "dry" due to the decrease in water levels. The expansion of the zones of transport for well CV-4.1 was accompanied by a change in the proportion of water from each source to well CV-4.1; more water was diverted to well CV-4.1 from the capture of discharge to other streams and river cells to compensate for the loss of induced infiltration, especially infiltration from the Columbia River. 
Under decreased horizontal hydraulic conductivity, the size and shape of the zones of transport were affected by an increase in the hydraulic gradient and a significant increase in induced infiltration from Burnt Bridge Creek and the Columbia River (fig. 10, table 6). In the selected group of cells, simulated water levels rose by an average of approximately $16 \mathrm{ft}$ in non-river cells; however, simulated water levels in river cells remained relatively unchanged, rising or declining less than 0.1 foot. Under decreased-conductivity conditions, the model simulated induced infiltration from Burnt Bridge Creek in four stream cells until available streamflow was depleted. The model also induced more infiltration from the Columbia River than under baseline conditions. The contraction of the zones of transport for well CV-4.1 was accompanied by a change in the proportion of water from each source to well CV-4.1; less water was diverted to well CV-4.1 from the capture of discharge to compensate for a significant gain of recharge from induced infiltration to well CV-4.1.

\section{Summary of Simulation Scenarios for Well CV-4.1}

Under baseline conditions, the zones of transport to CV-4.1 extended mainly to the northeast, following the trend in the hydraulic gradient within the unconsolidated sedimentary aquifer. Time of travel estimates suggested that most of the ground water that discharged from well CV-4.1 recharged the unconsolidated sedimentary aquifer within 50 years. Analysis of the pathlines also suggested that well CV-4.1 induces flow from the Columbia River and captures some ground water older than 50 years that would otherwise discharge to the river from the regional ground-water flow system.

Uncertainty in the porosity of the unconsolidated sedimentary and Troutdale gravel aquifers contributed more to the uncertainty in delineating the zones of transport for well CV-4.1 than did uncertainty in other factors, especially for travel times of 5 to 10 and 10 to 20 years. Changing the porosity by factors of 0.8 and 1.2 produced the greatest change in the area of each of the zones delineated for this well. The magnitude of these changes in the size of each zone indicated that the regional ground-water flow system contributes a significant amount of the ground water discharging from the well.

The proximity of the well CV-4.1 to the Columbia River has important implications for the quality of water discharging from the well. Well CV-4.1 induced as much as 10 percent of its total discharge from the Columbia River under baseline conditions and possibly more if other factors, such as the discharge rate of the well, were varied. Induced recharge from Columbia River has the potential to alter the quality of the water discharging from well CV-4.1 if the quality of water in the river is different from the quality of the ground water in the vicinity of the well.

Uncertainty in the withdrawal rates of nearby wells could have an important effect on the zones of transport delineated for well CV-4.1. Excluding all discharge from other wells produced the greatest change on the total area enclosed by the zones of transport and on the simulated water budget relative to baseline conditions. Under baseline conditions, a larger cone of depression for well CV-4.1 was required before sufficient discharge could be captured to offset its pumping. Excluding all discharge from other wells also produced the greatest change in the rate of recharge from induced infiltration from Burnt Bridge Creek and the Columbia River from baseline conditions.

\section{Clark Public Utility Well 19}

Clark Public Utility Well 19 (CPU-19) is located in the north-central part of the study area, adjacent to Salmon Creek (fig. 1). Well CPU-19 is part of the public water-supply system of Clark County. Well CPU-19 discharges at an average rate of approximately 380 gallons per minute $\left(0.85 \mathrm{ft}^{3} / \mathrm{s}\right)$.

\section{Local Hydrogeologic Setting}

Well CPU-19 discharges from the unconsolidated sedimentary aquifer, the water-table aquifer, which was simulated by uppermost layer in the Portland Basin model. The aquifer is approximately $50 \mathrm{ft}$ thick at the well site and overlies the Troutdale gravel aquifer, which is about $140 \mathrm{ft}$ thick and was simulated by layer 2 . The Troutdale gravel aquifer crops out at the land surface about 2 miles northeast of the well CPU-19. Undifferentiated fine-grained deposits that underlie the Troutdale gravel aquifer, which are approximately $1,050 \mathrm{ft}$ thick, were simulated by layers 3 through 7. Older rocks that underlie the undifferentiated fine-grained deposits were simulated by layer 8 . South of Salmon Creek, confining unit 1, Troutdale sandstone aquifer, and confining unit 2 replace the undifferentiated fine-grained deposits. Well CPU-19 is located in row 29, column 21 of the Portland Basin model grid (fig. 11). 


\section{WELL DISCHARGE}

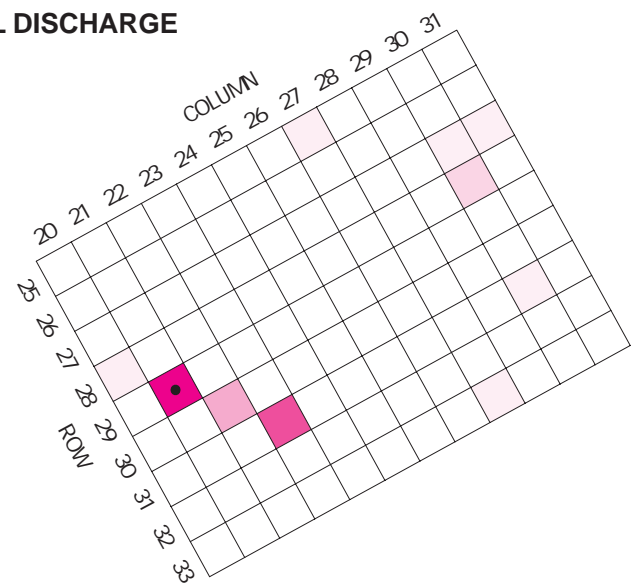

Discharge (negative), in cubic feet per second

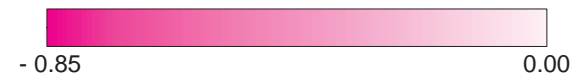

\section{RECHARGE}

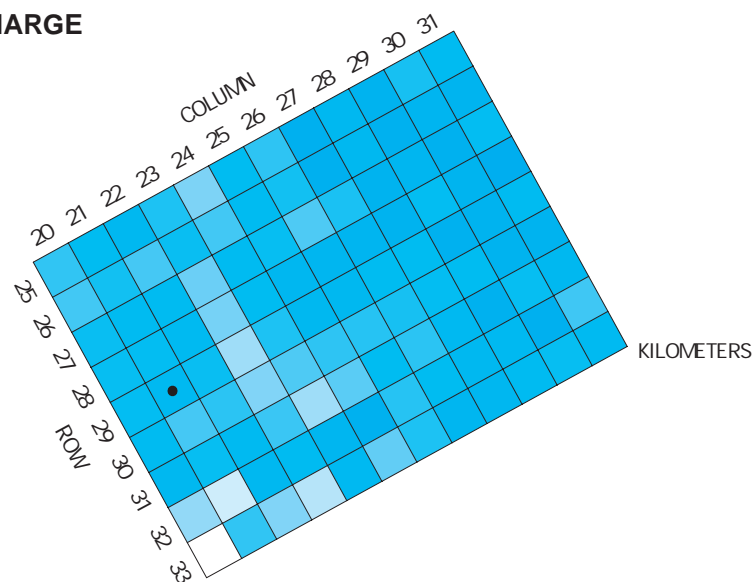

Recharge (positive), in cubic feet per second

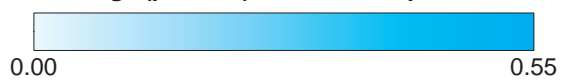

RIVER AND STREAM LEAKAGE

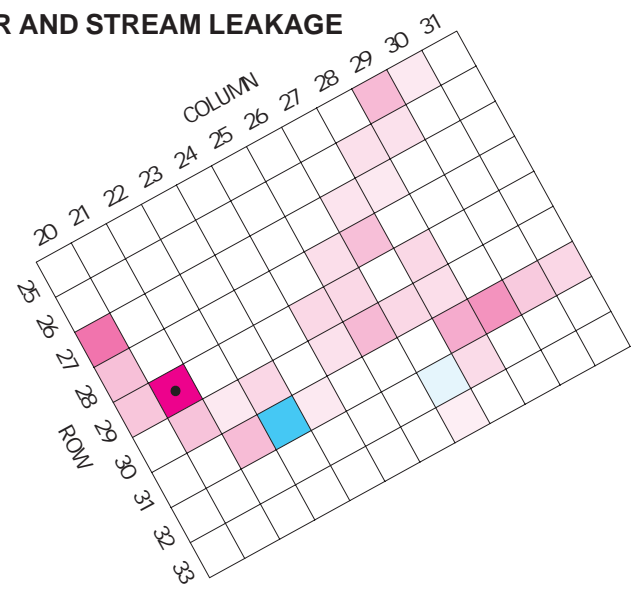

Discharge (negative) or recharge (positive), in cubic feet per second

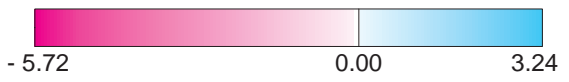

TRANSMISSIVITY
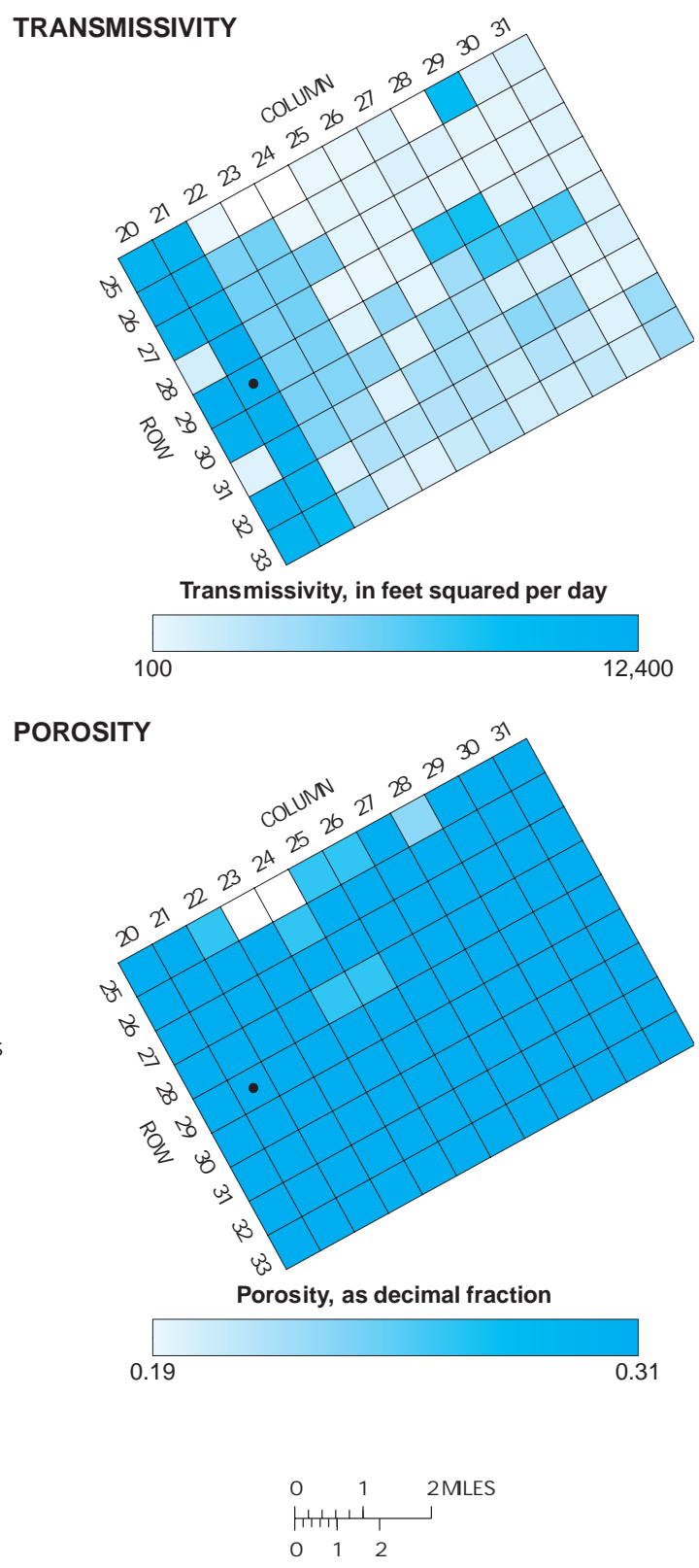

EXPLANATION

- Well CPU1 9

Figure 11. Simulated baseline conditions in layer 1, near well CPU-19. (Source: Morgan and McFarland, 1996.) 
The simulated distributions of well discharge, recharge, and stream leakage in layer 1 of the Portland Basin model for a selected group of 108 cells in layer 1 surrounding well CPU-19 are shown in figure 11. Well discharge for this group of cells containing wells ranges from 0.01 to $0.89 \mathrm{ft}^{3} / \mathrm{s}$. Areal recharge in the selected cells ranges from 0.0 to $0.57 \mathrm{ft}^{3} / \mathrm{s}$. The zero value in the extreme southern cell is in an urban area with a high percentage of impervious surfaces that restrict recharge (Snyder and others, 1994).

Simulated stream leakage ranges from -5.72 to $3.24 \mathrm{ft}^{3} / \mathrm{s}$ for cells representing Salmon Creek and tributaries of Salmon Creek; these streams are shown in figure 11. The baseline model simulated recharge from induced infiltration from Salmon Creek in 2 stream cells in the selected group of cells; in 31 other stream cells, the model simulated ground-water discharge to the stream. Induced recharge from Salmon Creek has the potential to alter the quality of the water discharging from well CPU-19 if the quality of water in the creek is different from the quality of the ground water in the vicinity of the well.

The local simulated transmissivity of model layer 1 ranges from 100 to $12,400 \mathrm{ft}^{2} / \mathrm{d}$ across the selected group of cells (fig. 11). The variation in transmissivity relates to changes in thickness and hydraulic conductivity within the unconsolidated sedimentary and Troutdale gravel aquifers in the selected cells of layer 1 . The transmissivity of cells representing the unconsolidated sedimentary aquifer ranges from 900 to $12,400 \mathrm{ft}^{2} / \mathrm{d}$ in the vicinity of well CPU-19. The transmissivity of cells representing the Troutdale gravel aquifer ranges from 100 to $3,750 \mathrm{ft}^{2} / \mathrm{d}$. Simulated effective porosity of model layer 1 ranges from 0.19 to 0.30 across the selected group of cells (fig. 11). Values of porosity for the unconsolidated sedimentary aquifer are near 0.30 , whereas values of porosity for the Troutdale gravel aquifer are about 0.20 .

\section{Zones of Transport and Simulated Water Budget for the Baseline Simulation}

The zones of transport for well CPU-19 were delineated by tracking particles along pathlines in the reverse direction of ground-water flow, starting from one cell in layer 1 at row 29 , column 21 . The reversedirection pathlines of these particles were to the east in the upgradient direction, approximately perpendicular to lines of equal simulated hydraulic head in the unconsolidated sedimentary and Troutdale gravel aquifers in layer 1 (fig. 12).
The particle pathlines indicated that most of the water that discharges from well CPU-19 had recharged the unconsolidated sedimentary aquifer within 50 years. Analysis of the pathlines also suggests that a smaller part of well CPU-19's discharge is more than 50 years old and flows through the underlying Troutdale gravel aquifer from recharge areas northeast of the well.

The simulated water budget for the selected group of cells is listed in table 8 . Recharge from precipitation and dry wells supplied 68 percent of the total inflow in the baseline simulation, ground water flowing into the selected group of cells from underlying cells of model layer 2 (inflow, bottom face) provided 21 percent, ground water flowing into the selected group of cells from surrounding cells of model layer 1 (inflow, side faces) provided 5 percent, and induced infiltration from Salmon Creek (inflow, streams) contributed 5 percent. Water from induced infiltration was not an important source for well CPU-19 because the model did not simulate any induced infiltration in the stream cell containing well CPU-19. Although it does not induce recharge from Salmon Creek, well CPU-19 captures ground water that would otherwise discharge to the creek. Induced infiltration was simulated in two stream cells, but this water probably was diverted by pumping wells contained in these streams cells or adjacent cells.

Simulated discharge of ground water from cells to Salmon Creek (outflow, streams) accounted for 58 percent of the total outflow, discharge to underlying cells in layer 2 (outflow, bottom face) accounted for 25 percent, discharge of ground water from the selected group of cells to adjacent cells in layer 1 (outflow, side faces) accounted for 14 percent, and discharge from wells (outflow, wells) accounted for 3 percent.

The size and shape of the zones of transport (fig. 12) were influenced by several factors. The principal factor influencing the shape of the zones of transport for well CPU-19 is its location in the stream valley of Salmon Creek. Except for reaches of Salmon Creek where heavy pumping induced infiltration, all of the reaches in the vicinity of CPU- 19 were simulated as gaining reaches. The influence of the creek on the hydraulic head distribution is evident from the V-shaped lines of equal simulated head (fig. 12). The shape of the lines indicates that ground-water flow paths converge in the area where discharge to the streams occurs. The convergent flow paths near well CPU-19 result in the fan-shaped zones of transport oriented to the northeast. To a lesser extent the shape of the zones of transport were influenced by the spatial changes in transmissivity and porosity, and the recharge distribution. 


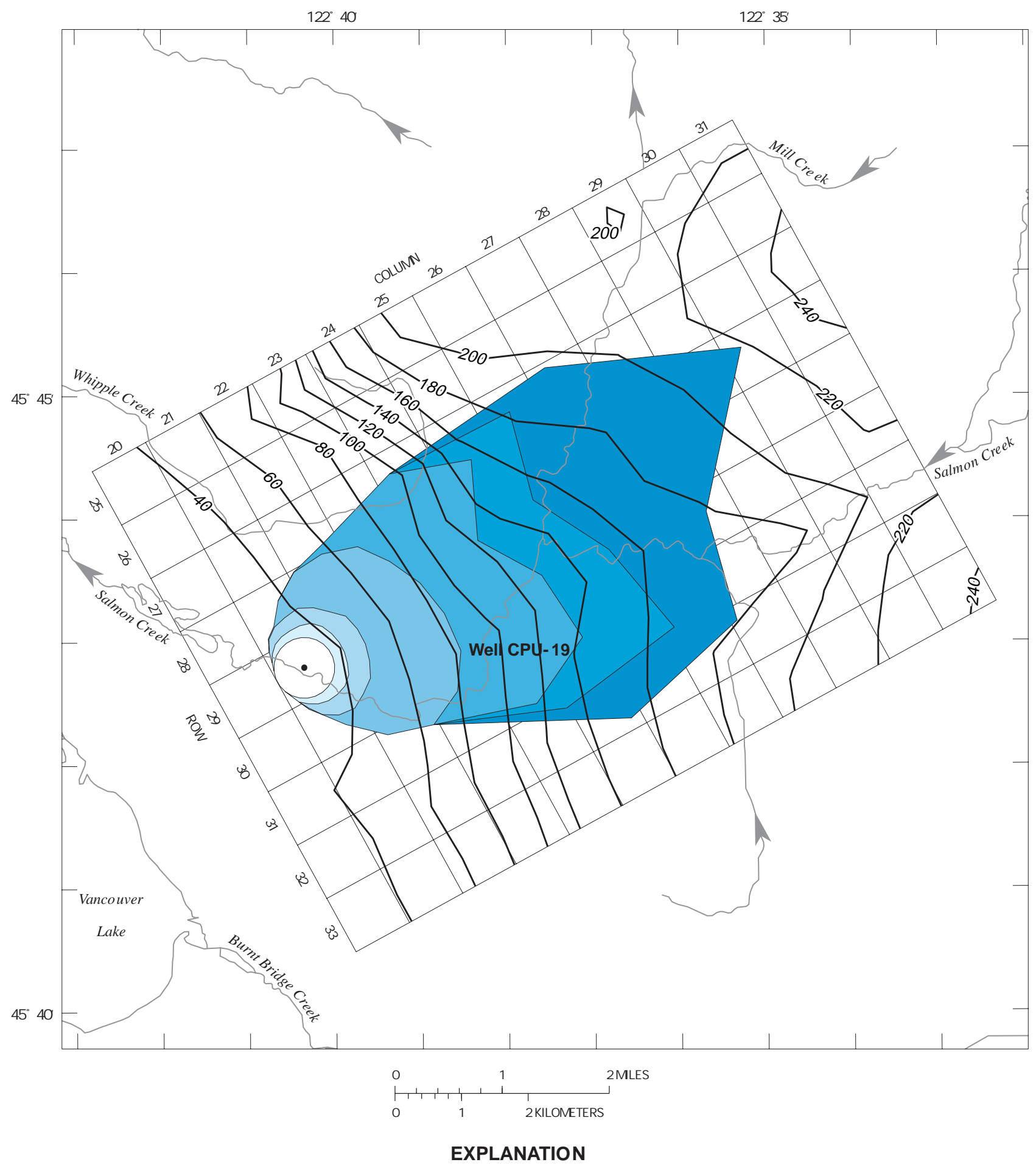

Zones of transport-value indicates time of travel in years.

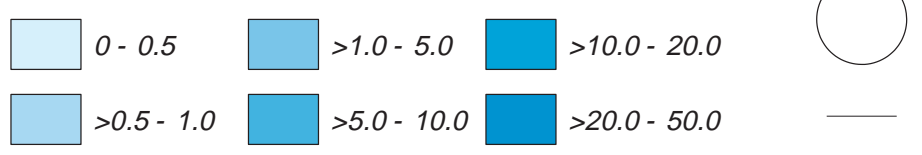

Particle starting area

Model cell boundary
Line of equal simulated hydraulic head for 1987-88 in model layer 1 . Contour interval 20 feet.

Figure 12. Projected zones of transport for well CPU-19, under baseline conditions ( $>$, greater than; <, less than; =, equal to). The direction of streamflow in Salmon Creek is from east to west. 
Table 8. Simulated water budget in a selected group of cells in layer 1 surrounding well CPU-19, under different hydrologic conditions [> less than]

\begin{tabular}{|c|c|c|c|c|c|c|}
\hline \multirow{2}{*}{\multicolumn{2}{|c|}{$\begin{array}{c}\text { Hydrologic source } \\
\text { or sink } \\
\text { or cell face } \\
\end{array}$}} & \multirow{2}{*}{$\begin{array}{c}\text { Baseline } \\
\text { flow } \\
\text { rate }^{1} \\
\end{array}$} & Increased-discharge & No-interference & Increased-conductivity & Decreased-conductivity \\
\hline & & & Percent change $^{2}$ & Percent change $^{2}$ & Percent change $^{2}$ & Percent change $^{2}$ \\
\hline \multirow{8}{*}{$\frac{3}{\underline{\underline{E}}}$} & Recharge & 44.3 & 0.0 & 0.0 & 0.0 & 0.0 \\
\hline & Drains & 0 & 0 & 0 & 0 & 0 \\
\hline & Rivers & 0 & 0 & 0 & 0 & 0 \\
\hline & Streams & 3.3 & 0 & -43.4 & 11.7 & -18.4 \\
\hline & Side faces & 3.5 & 0 & 35.9 & -2.2 & 4.9 \\
\hline & Top face & 0 & 0 & 0 & 0 & 0 \\
\hline & Bottom face & 13.6 & 0 & 20.9 & -1.0 & 1.1 \\
\hline & Total or net & 64.7 & 0 & 4.0 & .3 & -.5 \\
\hline \multirow{11}{*}{ 交 } & Recharge & 0 & 0 & 0 & 0 & 0 \\
\hline & Drains & 0 & 0 & 0 & 0 & 0 \\
\hline & Rivers & 0 & 0 & 0 & 0 & 0 \\
\hline & Streams & 37.6 & -1.1 & 14.1 & -7.1 & 6.1 \\
\hline & Wells & 2.1 & 20.5 & -59.5 & 0 & 0 \\
\hline & Side faces & 8.8 & -.1 & 7.5 & 17.0 & -16.2 \\
\hline & Top face & 0 & 0 & 0 & 0 & 0 \\
\hline & Bottom face & 16.2 & 0 & -12.7 & 8.8 & -7.5 \\
\hline & Total or net & 64.7 & $>.1$ & 4.0 & .4 & -.5 \\
\hline & Area $^{3}$ & 9,514 & .7 & -.2 & 4.6 & -10.9 \\
\hline & Hydraulic head ${ }^{4}$ & --- & $>-.1$ & 3 & -5 & 6 \\
\hline
\end{tabular}

\footnotetext{
1 The flow rate for baseline simulation, inflow to and outflow from the set of model cells (in cubic feet per second).

2 Percent change when compared to baseline simulation.

3 Value of the area enclosed by the zones of transport (50 year time of travel) from table 9 for baseline simulation (in square feet times $10^{4}$ ), values for the remaining simulations are the percent change in cumulative area taken from table 9.

4 Average change of hydraulic head from baseline conditions (in feet) for the selected group of cells.
}

\section{Zones of Transport and Simulated Water Budget for the Increased-Discharge Simulation}

Increasing the discharge rate of well CPU-19 by a factor of 1.5 resulted in a slight expansion of the zones of transport (fig. 13, table 9). The total area enclosed by the zones of transport increased by less than 1 percent from the baseline simulation, and the shape of each zone remained relatively unchanged; however, the number of particles used to delineate each zone that follow pathlines in cells in layer 2 doubled from baseline conditions.

Simulated ground-water levels declined by less than 0.2 foot from baseline conditions (table 8). This decline did not affect induced infiltration, because induced infiltration was not a significant source of water to this well. However, the decline did reduce the gradient between the stream and ground-water levels beneath the stream, thereby reducing ground-water discharge to Salmon Creek and streamflow in the creek. Most of the increased pumpage was from captured discharge. No additional water was gained from areally distributed recharge from the infiltration of precipitation, because the total recharge into the selected group of cells remained unchanged from baseline conditions.

\section{Zones of Transport and Simulated Water Budget for the No-Interference Simulation}

When all other discharge but that of well CPU-19 was excluded from the Portland Basin model, the size and shape of the zones of transport were affected, but the total area enclosed by these zones decreased by less than 1 percent (table 9). 
INCREASED DISCHARGE

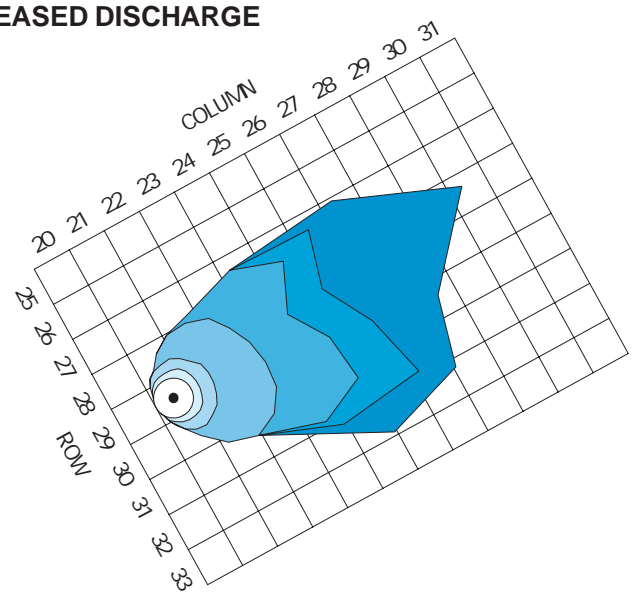

INCREASED POROSITY

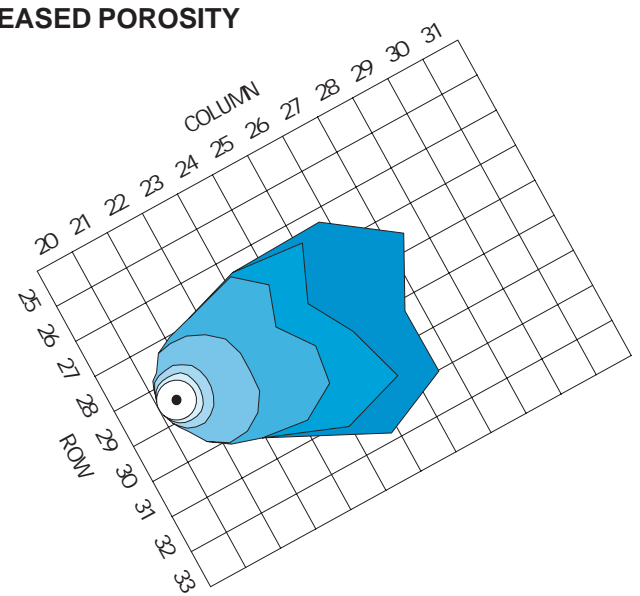

INCREASED CONDUCTIVITY

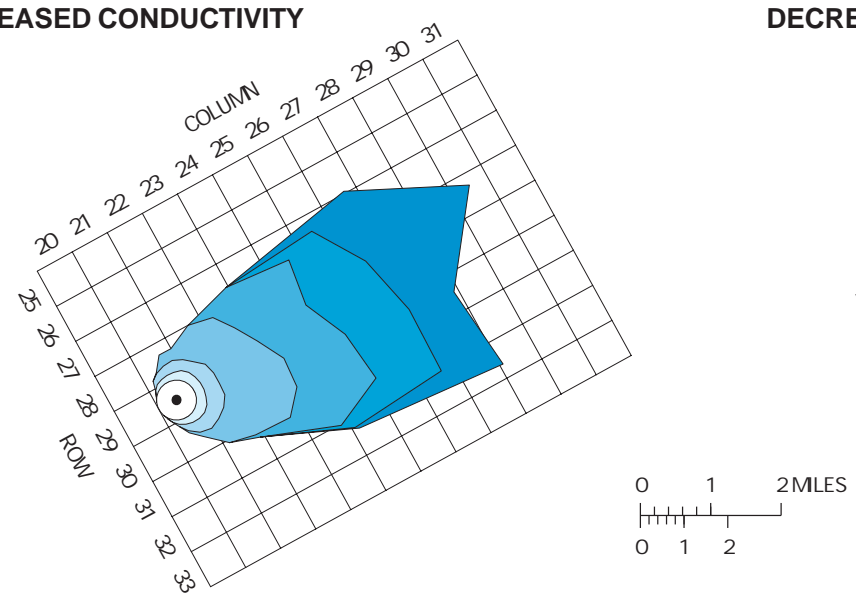

EXPLANATION

Zones of transport-value indicates time of travel in years.

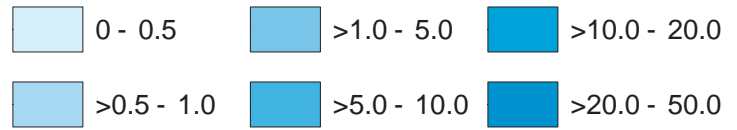

NO INTERFERENCE

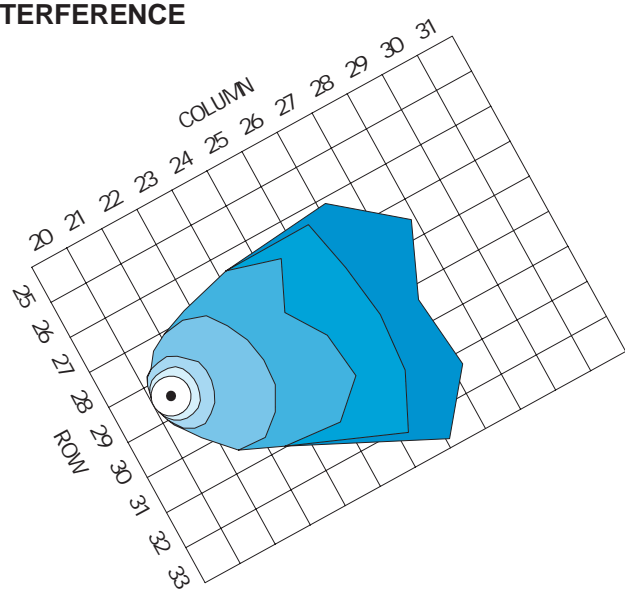

DECREASED POROSITY

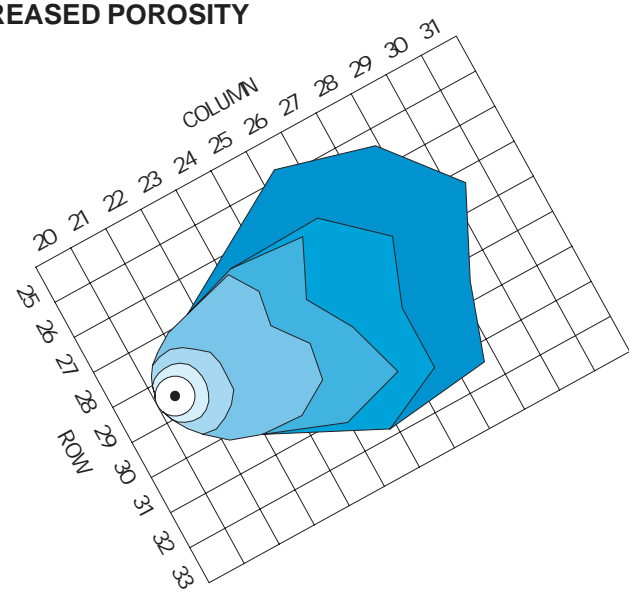

DECREASED CONDUCTIVITY

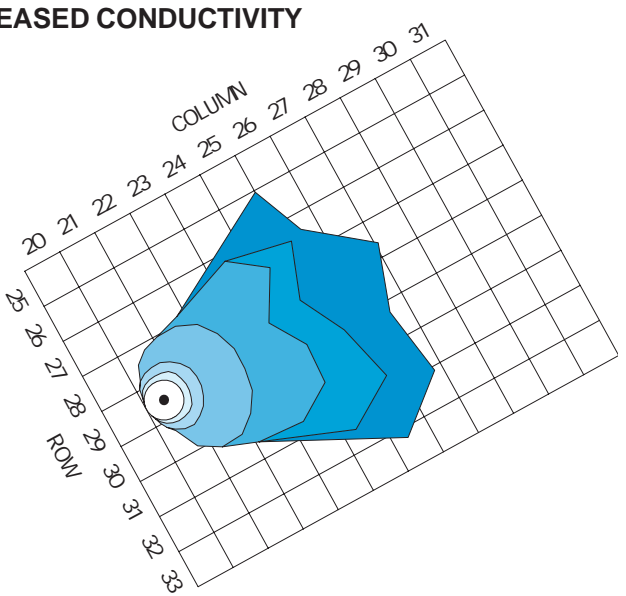

Particle starting area

Model cell boundary

- Well CPU-19

Figure 13. Projected zones of transport for well CPU-19, under different simulated hydrologic conditions ( $>$, greater than; <, less than; =, equal to). 
Table 9. Areas of projected zones of transport for different simulations for well CPU-19

\begin{tabular}{|c|c|c|c|c|c|c|c|c|c|c|c|c|c|c|}
\hline \multirow[b]{3}{*}{$\begin{array}{c}\text { Time } \\
\text { (years) }\end{array}$} & \multicolumn{2}{|c|}{ Baseline } & \multicolumn{2}{|c|}{ Increased-discharge } & \multicolumn{2}{|c|}{ No-Interference } & \multicolumn{2}{|c|}{ Increased-porosity } & \multicolumn{2}{|c|}{ Decreased-porosity } & \multicolumn{2}{|c|}{ Increased-conductivity } & \multicolumn{2}{|c|}{ Decreased-conductivity } \\
\hline & & & Perc & ent change & Perc & nt change & Perce & nt change & Perce & nt change & Perce & nt change & Perc & nt change \\
\hline & Area $^{1}$ & $\begin{array}{c}\text { Cumulative } \\
\text { area }^{2}\end{array}$ & Area $^{3}$ & $\begin{array}{l}\text { Cumulative } \\
\text { area }^{4}\end{array}$ & Area $^{3}$ & $\begin{array}{l}\text { Cumulative } \\
\text { area }^{4}\end{array}$ & Area $^{3}$ & $\begin{array}{c}\text { Cumulative } \\
\text { area }^{4}\end{array}$ & Area $^{3}$ & $\begin{array}{l}\text { Cumulative } \\
\text { area }^{4}\end{array}$ & Area $^{3}$ & $\begin{array}{l}\text { Cumulative } \\
\text { area }^{4}\end{array}$ & Area $^{3}$ & $\begin{array}{l}\text { Cumulative } \\
\text { area }^{4}\end{array}$ \\
\hline 0.5 & 134 & 348 & 0.7 & 0.3 & 3.1 & 1.2 & -28.5 & -11.0 & 66.3 & 25.6 & 10.9 & 4.2 & -12.8 & -5.0 \\
\hline 1.0 & 271 & 619 & 1.0 & .6 & 5.7 & 3.2 & -29.6 & -19.2 & 73.8 & 46.7 & 14.2 & 8.6 & -12.4 & -8.2 \\
\hline 5 & 1,367 & 1,986 & .3 & .4 & 9.7 & 7.7 & -26.6 & -24.3 & 66.0 & 60.0 & 11.0 & 10.3 & -10.1 & -9.5 \\
\hline 10 & 2,134 & 4,120 & .7 & .6 & 10.6 & 9.2 & -12.3 & -18.1 & -8.4 & 24.5 & 5.0 & 7.6 & -2.5 & -5.9 \\
\hline 20 & 1,667 & 5,787 & -2.7 & -.4 & 44.7 & 19.4 & 2.6 & -12.1 & 44.9 & 30.4 & 35.8 & 15.7 & -.4 & -4.3 \\
\hline 50 & 3,727 & 9,514 & 2.3 & .7 & -30.7 & -.2 & -29.4 & -18.9 & 22.0 & 27.1 & -12.7 & 4.6 & -21.1 & -10.9 \\
\hline
\end{tabular}

1 The area of the projected zones of transport for each selected time of travel for the baseline simulation, (in square feet times $10^{-4}$ ).

2 Summation of areas for this and all previous time steps for the baseline simulation, including the starting area, (in square feet times $10^{-4}$ ).

3 Percent change in area is the area for a simulation minus the area for the baseline simulation divided by the area for the baseline simulation.

4 Percent change in cumulative area is the cumulative area of a simulation minus the area of the baseline simulation divided by the area of the baseline simulation. 
The areas of all zones of transport of less than 20 years increased; however, these increases were offset by the 31 percent decrease in the area for the zones of transport of 20 to 50 years. The reduction in area of the 20 to 50 year zones of transport shows that well CPU-19 is able to capture more discharge from areas with shorter times of travel when other wells are not in the simulation. Particles delineating the northern part of this zone did not follow pathlines that extended as far from well CPU-19 as they did in the baseline simulation (figs. 12 and13).

Although the total area enclosed by the zones of transport did not change significantly, the removal of interfering wells did affect the simulated water levels and water budget in the selected group of cells. Simulated ground-water levels in the selected cells rose from less than 1 foot to almost $16 \mathrm{ft}$ above those from the baseline simulation. Cells in the southern part, where the concentration of discharging wells was the highest under baseline conditions, had the greatest rise. The model simulated 14 percent more groundwater discharge to streams in the selected group of cells under no-interference conditions because the hydraulic gradient between the aquifer and streams was greater. The increase in water levels was accompanied by an increase in inflow to the selected cells from surrounding cells in layers 1 and 2, an increase of discharge to adjacent cells in layer 1, and a loss of discharge to underlying cells (table 9). The discharges from wells near to well CPU-19 affected the pattern of ground-water flow and the ground-water gradient under baseline conditions.

\section{Zones of Transport for the Increased-Porosity and Decreased-Porosity Simulations}

Under increased- and decreased-porosity conditions, the size and shape of the zones of transport delineated for well CPU-19 differed significantly from those in the baseline simulation (fig. 13). The total area enclosed by the zones of transport decreased by about 19 percent under increased-porosity conditions and increased 27 percent under decreased-porosity conditions.

For increased porosity values, the zones did not extend as far from well CPU-19 because ground water moved to the well more slowly than under baseline conditions. The areas of the zones of transport for times of travel other than 10 to 20 years were reduced. The increase in area for the 10 to 20 year zone of transport resulted from a reduction of the 5 to 10 year zone caused by a change in particle velocities related to an east-west transition from rocks of the undifferentiated fine-grained deposits to rocks of the confining unit 1 and Troutdale sandstone aquifer.

For decreased porosity values, the zones extended farther from well CPU-19 because ground water moved to the well more rapidly than under baseline conditions. The areas of the zones of transport for times of travel other than for 5 to 10 years increased. The reduction in the area for the 5 to 10 year zone of transport resulted from a greater increase of the 1 to 5 year zone caused by a change in particle velocities related to an east-west transition from rocks of the undifferentiated fine-grained deposits to rocks of the confining unit 1 and Troutdale sandstone aquifer.

\section{Zones of Transport and Simulated Water Budget for the Increased-Conductivity and Decreased-Conductivity Simulations}

Varying the horizontal hydraulic conductivity from the baseline simulation affected the water budget, water levels, and the shape of the zones of transport, but the total area enclosed by all zones changed by less than 11 percent (tables 8 and 9). Under increased-conductivity conditions, the size and shape of each zone of transport delineated for well CPU-19 (fig. 13) were influenced by a change in the hydraulic gradient caused by an overall decline in simulated water levels in the selected group of cells. Simulated water levels in the unconsolidated sedimentary and the Troutdale gravel aquifers generally declined by an average of approximately $5 \mathrm{ft}$ from baseline conditions; however, simulated water levels at well CPU-19 and downstream of the well rose less than 1 foot. The zones of transport extended farther to the east from well CPU-19 than those in the baseline simulation, indicating a greater east to west ground-water velocity. Overall, increasing the values of horizontal hydraulic conductivity influenced particle velocity, which resulted in an increase of less than 5 percent in the total area enclosed by the zones from baseline conditions.

Under decreased-conductivity conditions, the size and shape of each zone of transport delineated for well CPU-19 (fig. 13) were influenced by a change in the hydraulic gradient caused by an overall rise in simulated water levels in the selected group of cells. Simulated water levels in the unconsolidated sedimentary and the Troutdale gravel aquifers generally rose by an average of approximately $6 \mathrm{ft}$ from baseline conditions; however, simulated water levels in many of the stream cells including the cell containing well CPU-19 rose by less than 1 foot 
The zones of transport did not extend as far from well CPU-19, but were wider than as those in the baseline simulation, indicating more convergent ground-water flow paths in the area where discharge to the streams occurs. Overall, decreasing the values of horizontal hydraulic conductivity decreased particle velocity, which resulted in an decrease of nearly 11 percent in the total area enclosed by the zones from baseline conditions.

\section{Summary of Simulation Scenarios for Well CPU-19}

Under baseline conditions, the zones of transport to CPU-19 extended mainly to the northeast following the trend in the hydraulic gradient within the unconsolidated sedimentary and Troutdale gravel aquifers. Time of travel estimates suggest that most of the ground water that discharges from well CPU-19 recharged the unconsolidated sedimentary and Troutdale gravel aquifers within 50 years. Analysis of the pathlines also suggests that well CPU-19 does not induce infiltration from the Salmon Creek, but does capture some ground water older than 50 years that would otherwise discharge to the creek. The principal factor influencing the fan-shaped zones of transport for well CPU-19 is its location in the stream valley of Salmon Creek. The fan-shaped zones of transport oriented to the northeast result from convergent flow paths near well CPU-19.

Uncertainty in the porosity of the unconsolidated sedimentary and Troutdale gravel aquifers contributed more to the uncertainty in delineating the zones of transport for well CPU-19 than did uncertainty in other factors. Changing the porosity by factors of 0.8 and 1.2 produced the greatest change in the area of each of the zones delineated for this well. The magnitude of these changes in the size of each zone indicates that intermediate and regional groundwater flow systems contribute a significant amount of the ground water discharging from the well.

Increasing the discharge of well CPU-19 did not significantly expand the total area enclosed by the zones of transport for well CPU-19 from the baseline conditions. Although pumping of well CPU-19 under increased-discharge conditions did not induce water to infiltrate from Salmon Creek, pumping of well CPU-19 did capture water that would otherwise have discharged to Salmon Creek. The significance of ground-water discharge to Salmon Creek and the high rate of recharge from underlying cells into the selected group of cells indicates that intermediate and regional ground-water flow systems that would otherwise discharge to Salmon Creek are important sources of water to well CPU-19.

\section{Clark Public Utility Well 9}

Clark Public Utility Well 9 (CPU-9) is located in the north-central part of the study area, adjacent to Salmon Creek (fig. 1). This well is part of the public water-supply system of Clark County. Well CPU-9 discharges at an average rate of approximately 660 gallons per minute $\left(1.5 \mathrm{ft}^{3} / \mathrm{s}\right)$.

\section{Local Hydrogeologic Setting}

Well CPU-9 discharges from the Troutdale gravel aquifer, the water-table aquifer, which was simulated by the two uppermost layers in the model. The Troutdale gravel aquifer is approximately $120 \mathrm{ft}$ thick at the well site and overlies $1,200 \mathrm{ft}$ of undifferentiated fine-grained deposits. These deposits were simulated by layers 3 through 7 . Older rocks underlie these deposits and were simulated by layer 8 . The Troutdale gravel aquifer crops out in most of the cells representing stream reaches of Salmon Creek in the vicinity of the well. The unconsolidated sedimentary aquifer crops out and overlies the Troutdale gravel aquifer in the remaining cells. East of the well, confining unit 1, the Troutdale sandstone aquifer, and confining unit 2 replace the undifferentiated fine-grained deposits. Well CPU-9 is located in row 31, column 23 of the model grid (fig. 14). This well is near the previously discussed well CPU-19 (row 29, column 21), which is located farther downstream in the valley of Salmon Creek.

The simulated local distributions of well discharge, recharge, and stream leakage in layers 1 and 2 of the Portland Basin model are shown in figure 14 for a selected group of 66 cells in each layer surrounding well CPU-9. Well discharge for this group of cells containing wells ranges from less than 0.04 to $1.7 \mathrm{ft}^{3} / \mathrm{s}$. Areal recharge by infiltration of precipitation and from drywells into the ground-water system in the selected cells ranges from 0.12 to $0.54 \mathrm{ft}^{3} / \mathrm{s}$. Simulated stream leakage to and from Salmon Creek ranges from -2.90 to $3.24 \mathrm{ft}^{3} / \mathrm{s}$. Induced infiltration from stream reaches of Salmon Creek has the potential to alter the quality of the water discharging from well CPU-9 if the quality of the water in the stream is different from the quality of the ground water in the vicinity of the well. 
WELL DISCHARGE

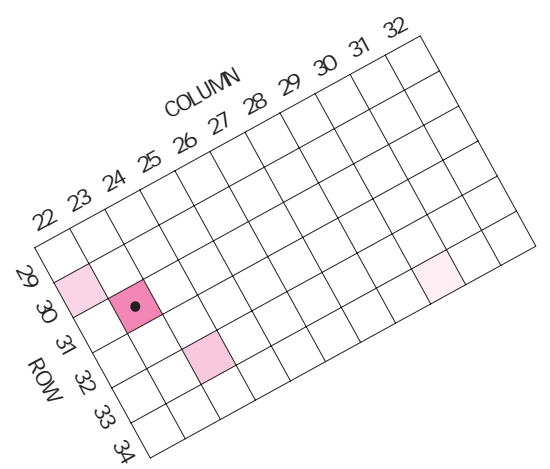

Discharge (negative), in cubic feet per second

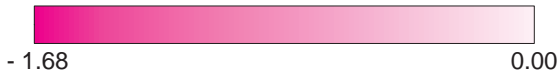

RECHARGE

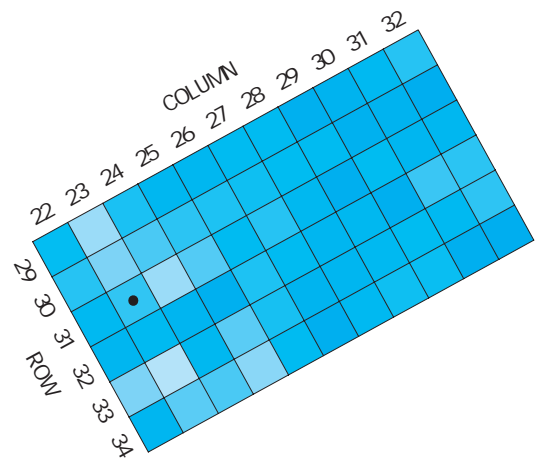

Recharge (positive), in cubic feet per second

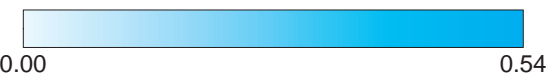

RIVER AND STREAM LEAKAGE

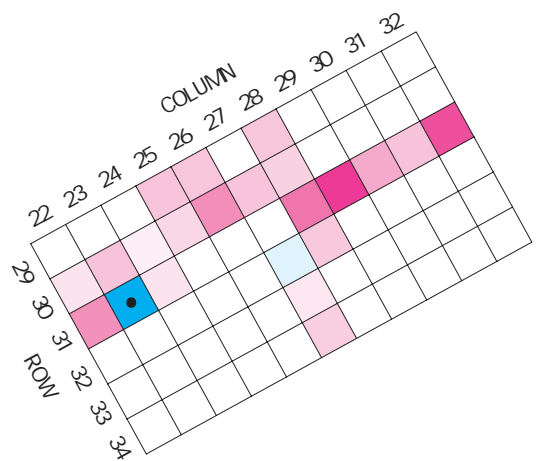

TRANSMISSIVITY
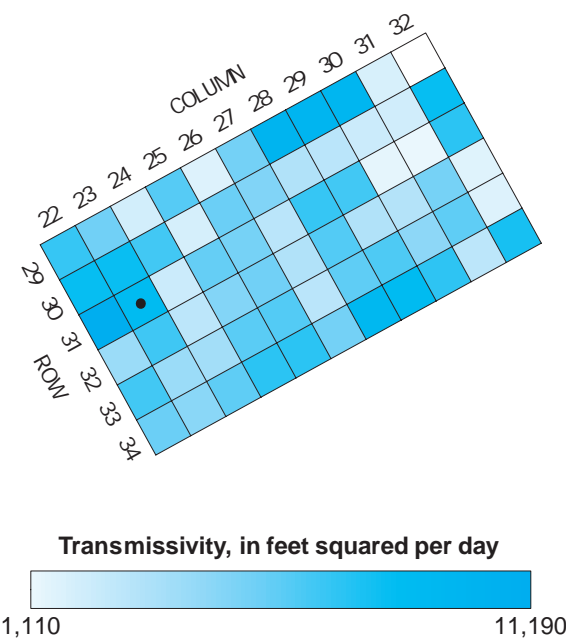

POROSITY
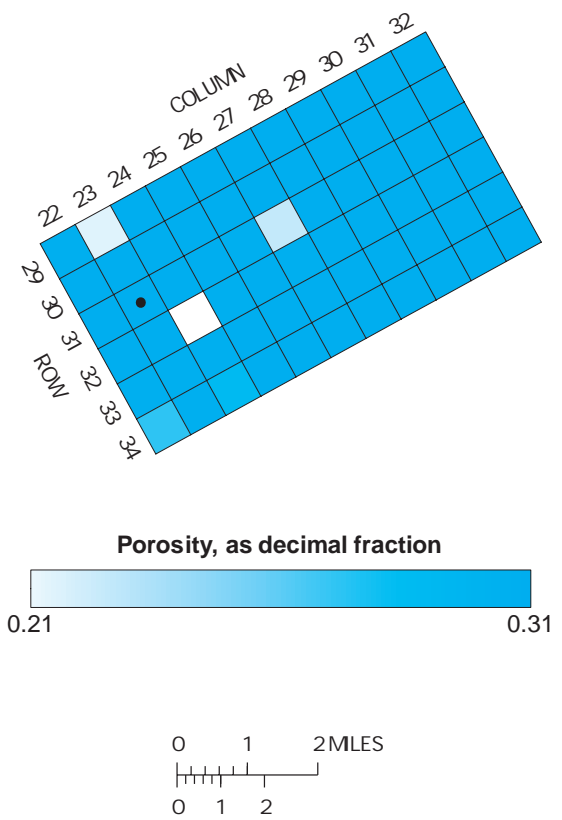

EXPLANATION

- Well CPU9

Discharge (negative) or recharge (positive), in cubic feet per second

\begin{tabular}{ll|l|}
\hline & & \\
-2.90 & 0.00 & 3.24
\end{tabular}

Figure 14. Simulated baseline conditions in layers 1 and 2, near well CPU-9. (Source: Morgan and McFarland, 1996.) 
The local simulated transmissivity of model layers 1 and 2 ranges from about 1,100 to $11,200 \mathrm{ft}^{2} / \mathrm{d}$ across the selected group of cells (fig. 14). The variability in transmissivity is due to the changes in thickness and hydraulic conductivity within the Troutdale gravel aquifer and to the presence of the unconsolidated sedimentary aquifer in cells of layers 1 and 2 . The local transmissivity of cells representing the Troutdale gravel aquifer ranges from about 300 to $9,000 \mathrm{ft}^{2} / \mathrm{d}$ in the vicinity of well CPU-9. The local transmissivity of cells representing the unconsolidated sedimentary aquifer ranges from about 450 to $7,500 \mathrm{ft}^{2} / \mathrm{d}$. The local simulated porosity distribution is relatively homogeneous, ranging from 0.21 to 0.31 in the Troutdale gravel and the unconsolidated sedimentary aquifers.

\section{Zones of Transport and Simulated Water Budget for the Baseline Simulation}

The zones of transport for well CPU-9 were delineated by tracking particles along pathlines in the reverse direction of ground-water flow, starting from the two cells in layers 1 and 2 at row 29, column 21 . The reverse-direction pathlines of these particles were to the east in the upgradient direction, approximately perpendicular to lines of equal simulated hydraulic head in the Troutdale gravel and unconsolidated sedimentary aquifers (fig. 15). The zones of transport intercept losing reaches of Salmon Creek.

The particle pathlines indicated that most of the water that discharges from well CPU-9 recharges the Troutdale gravel and the unconsolidated sedimentary aquifers within 50 years. Analysis of the pathlines also suggests that a smaller part of CPU-9's discharge is older than 50 years and flows through the underlying confining unit 1 from recharge areas northeast of the well.

The simulated water budget for the selected group of cells is listed in table 10. Areal recharge from precipitation and drywells supplied 68 percent of the total inflow in the baseline simulation, ground water flowing into this group of cells from surrounding cells in layers 1 and 2 (inflow, side faces) provided 18 percent of the total inflow, induced infiltration from Salmon Creek (inflow, streams) contributed 9 percent, and ground water flowing into this group of cells from underlying cells from model layer 3 (inflow, bottom face) provided 5 percent.

Simulated ground-water discharge from cells to Salmon Creek (outflow, streams) accounted for 52 percent of the total outflow, discharge of ground water from this group of cells to adjacent cells in layers
1 and 2 (outflow, side faces) accounted for 32 percent, and discharge to underlying cells in layer 3 (outflow, bottom face) accounted for 8 percent, and discharge from wells (outflow, wells) accounted for 7 percent.

The size and shape of the zones of transport for well CPU-9 shown in figure 15 were influenced by several factors. The zones of transport were elongated to the east along the principal direction of groundwater flow. The elongation of the zones of transport was due primarily to the high permeability of the Troutdale gravel and the unconsolidated sedimentary aquifers and large hydraulic gradients which resulted in high ground-water velocities.

\section{Zones of Transport and Simulated Water Budget for the Increased-Discharge Simulation}

Increasing the discharge rate of well CPU-9 by a factor of 1.5 resulted in a slight (4 percent) expansion of the total area of the zones of transport (fig. 16, table 11). The zones extended slightly farther from well CPU-9 than under baseline conditions because the hydraulic gradient to the well increased. Simulated ground-water levels declined by an average of less than 0.1 foot in the Troutdale gravel and unconsolidated sedimentary aquifers near the well from baseline conditions and only $2 \mathrm{ft}$ at the well site. Increasing the discharge rate of well CPU-9 caused the cone of depression to extend further in order to capture more discharge to Salmon Creek and induce 12 percent of more recharge into the Troutdale gravel aquifer from Salmon Creek near well CPU-9.

\section{Zones of Transport and Simulated Water Budget for the No-Interference Simulation}

When all well discharge other than that of well CPU-9 was excluded from the model, the total area enclosed by the zones of transport increased by 12 percent (fig. 16, table 11). The zones extended in a more southerly direction from well CPU-9 because the axis of the hydraulic gradient shifted toward an area where, under baseline conditions, other discharging wells are located. Simulated ground-water levels increased by an average of almost $5 \mathrm{ft}$ in the Troutdale gravel and unconsolidated sedimentary aquifers from baseline conditions and almost $2 \mathrm{ft}$ at the well site. In the absence of interfering wells, the gradient between the stream and ground-water levels at well CPU-9 was less than in baseline conditions, thereby reducing recharge from induced infiltration from Salmon Creek by about 20 percent. 


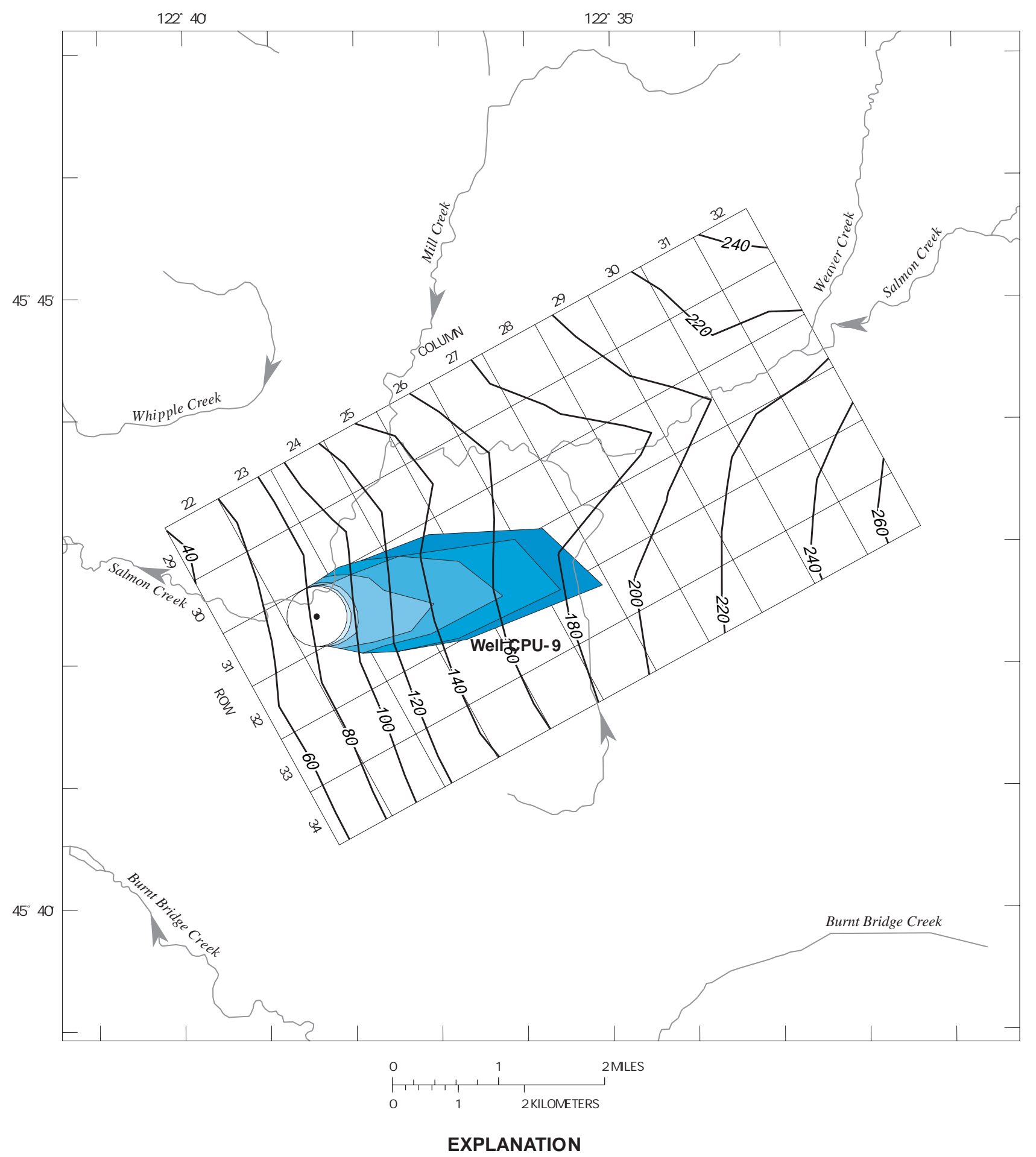

Zones of transport-value indicates time of travel in years.

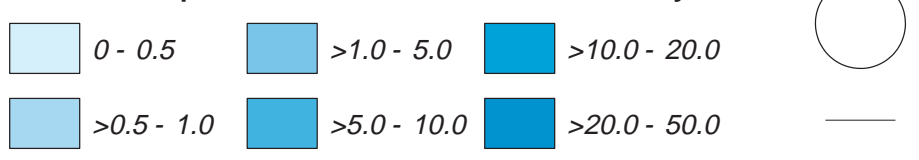

Particle starting area

Model cell boundary
Line of equal simulated hydraulic head for 1987-88 in model layer 1 . Contour interval 20 feet.

Figure 15. Projected zones of transport for well CPU-9, under baseline conditions (>, greater than; <, less than; =, equal to). The direction of streamflow in Salmon Creek is from east to west. 
Table 10. Simulated water budget in a selected group of cells in layers 1 and 2 surrounding well CPU-9, under different hydrologic conditions

\begin{tabular}{|c|c|c|c|c|c|c|}
\hline \multirow{2}{*}{\multicolumn{2}{|c|}{$\begin{array}{c}\text { Hydrologic source } \\
\text { or sink } \\
\text { or cell face }\end{array}$}} & \multirow{2}{*}{$\begin{array}{c}\text { Baseline } \\
\text { flow } \\
\text { rate }^{1} \\
\end{array}$} & Increased-discharge & No-interference & Increased-conductivity & Decreased-conductivity \\
\hline & & & Percent change $^{2}$ & Percent change ${ }^{2}$ & Percent change $^{2}$ & Percent change $^{2}$ \\
\hline \multirow{8}{*}{$\stackrel{z}{\underline{\underline{L}}} \underline{\underline{\underline{L}}}$} & Recharge & 26.2 & 0.0 & 0.0 & 0.0 & 0.0 \\
\hline & Drains & 0 & 0 & 0 & 0 & 0 \\
\hline & Rivers & 0 & 0 & 0 & 0 & 0 \\
\hline & Streams & 3.4 & 11.7 & -20.4 & 11.7 & -17.8 \\
\hline & Side faces & 6.8 & .3 & 33.0 & -5.9 & 6.8 \\
\hline & Top face & 0 & 0 & 0 & 0 & 0 \\
\hline & Bottom face & 2.1 & .5 & 27.0 & -9.3 & 4.7 \\
\hline & Total or net & 38.5 & 1.1 & 5.5 & -.5 & -.1 \\
\hline \multirow{11}{*}{$\frac{3}{\frac{3}{E}}$} & Recharge & 0 & 0 & 0 & 0 & 0 \\
\hline & Drains & 0 & 0 & 0 & 0 & 0 \\
\hline & Rivers & 0 & 0 & 0 & 0 & 0 \\
\hline & Streams & 20.2 & -1.2 & 21.3 & -14.3 & 12.1 \\
\hline & Wells & 2.8 & 26.6 & -47.1 & 0 & 0 \\
\hline & Side faces & 12.5 & -.5 & -5.0 & 18.2 & -18.0 \\
\hline & Top face & 0 & 0 & 0 & 0 & 0 \\
\hline & Bottom face & 3.0 & 0 & -9.1 & 14.1 & -8.8 \\
\hline & Total or net & 38.5 & 1.1 & & -.5 & -.1 \\
\hline & $\mathrm{Area}^{3}$ & 1,911 & 3.3 & 12.2 & 8.7 & -6.5 \\
\hline & Hydraulic head ${ }^{4}$ & --- & -.1 & 4.6 & -4.6 & 5.3 \\
\hline & \multicolumn{6}{|c|}{$\begin{array}{l}\text { Value of the area enclosed by all zones of transport ( } 50 \text { year time of travel) from table for baseline simulation (in square feet times } 10^{4} \text { ), } \\
\text { values for the remaining simulations are the percent change in cumulative area taken from table . }\end{array}$} \\
\hline
\end{tabular}

In the gaining reaches, the gradient between ground-water levels and streams was greater, thereby increasing ground-water discharge to Salmon Creek by about 21 percent. These conditions caused the cone-of-depression for well CPU-9 to extend farther and hence expand the zones of transport to capture more discharge to compensate for the reduction in recharge from induced infiltration.

\section{Zones of Transport for the Increased-Porosity and Decreased-Porosity Simulations}

The size and shape of the zones of transport delineated for well CPU-9 changed significantly from baseline conditions under increased-porosity and decreased-porosity conditions (fig. 16, table 11). The total area enclosed by the zones of transport decreased by about 13 percent under increased-porosity conditions and increased 37 percent under decreasedporosity conditions.
For increased porosity values, the zones did not extend as far from well CPU-9 because ground water moved to the well more slowly than under baseline conditions. The areas of the zones of transport for times of travel other than for 20 to 50 years were reduced. The increase in area for the 20 to 50 year zone of transport resulted from a reduction of the area for the 10 to 20 year zone caused by reduced particles velocities.

For decreased porosity values, the zones extended farther from well CPU-9 because ground water moved to the well more rapidly than under baseline conditions. The areas of the zones of transport for all times of travel other than for 10 to 20 years were increased. The large increase in the area for the 20 to 50 year zone of transport resulted from the small proportion of well CPU-9's discharge that flows through confining unit 1 and takes more than 50 years to reach the well. 

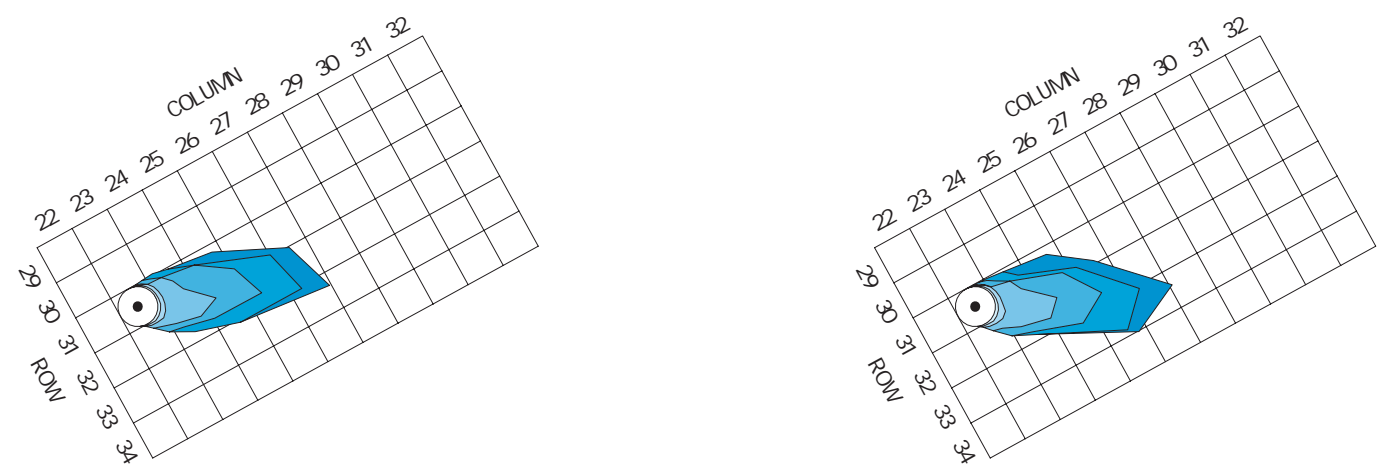

INCREASED POROSITY

DECREASED POROSITY
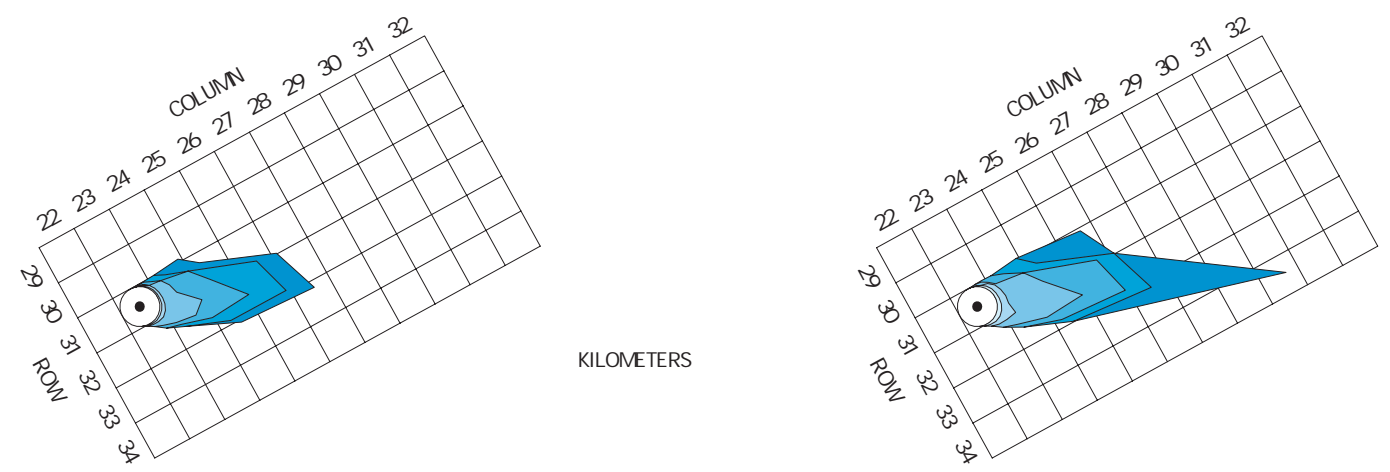

INCREASED CONDUCTIVITY

KILOMETERS

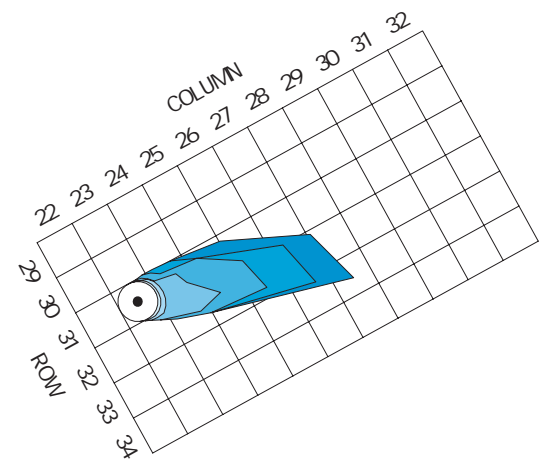

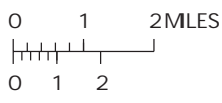

EXPLANATION

Zones of transport-value indicates time of travel in years.

$\square=0.5 \square>1.0-5.0 \square>10.0-20.0$
$\square>0.5-1.0 \square>5.0-10.0 \square>20.0-50.0$

DECREASED CONDUCTIVITY

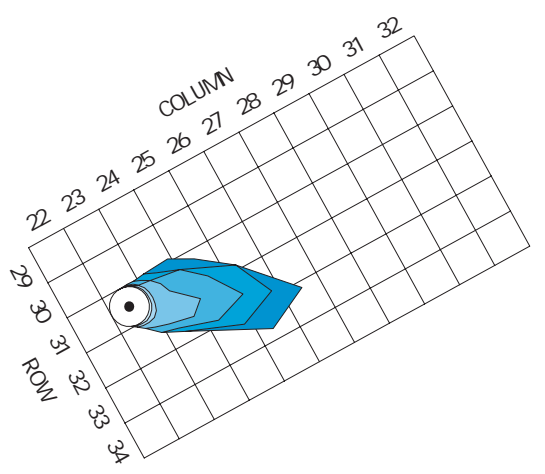

Particle starting area

Model cell boundary

- Well CPU- 9

Figure 16. Projected zones of transport for well CPU-9, under different simulated hydrologic conditions (>, greater than; <, less than; =, equal to). 
Table 11. Areas of projected zones of transport from different simulations for well CPU-9

\begin{tabular}{|c|c|c|c|c|c|c|c|c|c|c|c|c|c|c|}
\hline \multirow[b]{3}{*}{$\begin{array}{c}\text { Time } \\
\text { (years) }\end{array}$} & \multicolumn{2}{|c|}{ Baseline } & \multicolumn{2}{|c|}{ Increased-discharge } & \multicolumn{2}{|c|}{ No-Interference } & \multicolumn{2}{|c|}{ Increased-porosity } & \multicolumn{2}{|c|}{ Decreased-porosity } & \multicolumn{2}{|c|}{ Increased-conductivity } & \multicolumn{2}{|c|}{ Decreased-conductivity } \\
\hline & & & Perc & ent change & Perc & nt change & Perce & nt change & Perce & nt change & Perc & ent change & Perc & ent change \\
\hline & Area $^{1}$ & $\begin{array}{c}\text { Cumulative } \\
\text { area }^{2}\end{array}$ & Area $^{3}$ & $\begin{array}{l}\text { Cumulative } \\
\text { area }^{4}\end{array}$ & Area $^{3}$ & $\begin{array}{l}\text { Cumulative } \\
\text { area }^{4}\end{array}$ & Area $^{3}$ & $\begin{array}{c}\text { Cumulative } \\
\text { area }^{4}\end{array}$ & Area $^{3}$ & $\begin{array}{c}\text { Cumulative } \\
\text { area }^{4}\end{array}$ & Area $^{3}$ & $\begin{array}{l}\text { Cumulative } \\
\text { area }^{4}\end{array}$ & Area $^{3}$ & $\begin{array}{l}\text { Cumulative } \\
\text { area }^{4}\end{array}$ \\
\hline 0.5 & 20 & 233 & 4.9 & 0.4 & 11.9 & 1.0 & -27.6 & -2.4 & 62.1 & 5.3 & 9.3 & 0.8 & -12.2 & -1.0 \\
\hline 1 & 35 & 268 & 4.8 & 1.0 & 23.3 & 3.9 & -26.3 & -5.5 & 92.6 & 16.8 & 10.1 & 2.0 & -8.3 & -2.0 \\
\hline 5 & 281 & 549 & 3.2 & 2.1 & 19.0 & 11.6 & -29.2 & -17.6 & 54.0 & 35.8 & 1.2 & 1.6 & -7.8 & -4.9 \\
\hline 10 & 473 & 1,022 & 5.7 & 3.8 & 6.9 & 9.4 & -25.4 & -21.2 & 9.5 & 23.6 & 8.9 & 5.0 & -5.8 & -5.3 \\
\hline 20 & 508 & 1,510 & 10.1 & 5.9 & 8.9 & 9.3 & -7.0 & -16.5 & -22.4 & 8.4 & -3.5 & 2.2 & -16.9 & -9.2 \\
\hline 50 & 401 & 1,911 & -6.6 & 3.3 & 23.6 & 12.2 & 2.1 & -12.6 & 145.7 & 36.9 & 33.4 & 8.7 & 3.6 & -6.5 \\
\hline
\end{tabular}

1 The area of the projected zones of transport for each selected time of travel for the baseline simulation, (in square feet times $10^{-4}$ ).

2 Summation of areas for this and all previous time steps for the baseline simulation, including the starting area, (in square feet times $10^{-4}$ ).

Percent change in area is the area for a simulation minus the area for the baseline simulation divided by the area for the baseline simulation.

4 Percent change in cumulative area is the cumulative area of a simulation minus the area of the baseline simulation divided by the area of the baseline simulation. 


\section{Zones of Transport and Simulated Water Budget for the Increased-Conductivity and Decreased-Conductivity Simulations}

Varying the horizontal hydraulic conductivity from the baseline simulation affected the water budget and water levels, but the total area enclosed by the zones of transport changed less than 9 percent (tables 10 and 11). Increasing the horizontal hydraulic conductivity by a factor of 1.2 resulted in an approximately 9 percent increase in the total area of the zones of transport (fig. 16, table 11). The zones extended farther from well CPU-9 than under baseline conditions because ground water moved to the well more rapidly. Simulated ground-water levels declined by an average of almost $5 \mathrm{ft}$ in the Troutdale gravel and unconsolidated sedimentary aquifers from baseline conditions, and almost $2 \mathrm{ft}$ at the well site. The hydraulic gradient between the Troutdale aquifer and underlying rocks was less than under baseline conditions, thereby reducing recharge into the aquifer from underlying rocks, by about 10 percent. In the losing reaches of Salmon Creek, the gradient between the stream and ground-water levels at well CPU-9 was greater than under baseline conditions, causing a nearly 12 percent increase of recharge into the Troutdale aquifer from Salmon Creek. In the gaining reaches, the gradient between ground-water levels and streams was less, thereby decreasing ground-water discharge to Salmon Creek by about 14 percent. These conditions caused the zones of transport to expand in order to capture more discharge to compensate for the reduction in recharge into the Troutdale gravel and unconsolidated sedimentary aquifers from underlying rocks.

Decreasing the horizontal hydraulic conductivity by a factor of 0.8 resulted in a 7 percent reduction in the total area of the zones of transport (fig. 16, table 11). The zones did not extend as far as those from well CPU-9 under baseline conditions because ground water moved to the well more slowly. Simulated ground-water levels rose by an average of $6 \mathrm{ft}$ in the Troutdale gravel and unconsolidated sedimentary aquifers from baseline conditions, and almost $2 \mathrm{ft}$ at the well site. The hydraulic gradient between the Troutdale aquifer and underlying rocks was greater than under baseline conditions, thereby increasing recharge into the aquifer from underlying rocks by about 5 percent. In the losing reaches of Salmon Creek, the gradient between the stream and groundwater levels at well CPU-9 was less than under base- line conditions, causing a nearly 18 percent reduction of recharge into the Troutdale aquifer from Salmon Creek. In the gaining reaches, the gradient between ground-water levels and streams was greater, thereby increasing ground-water discharge to Salmon Creek by about 12 percent. These conditions reduced the zones of transport in order to capture more discharge to compensate for the reduction in recharge into the Troutdale gravel and unconsolidated sedimentary aquifers from underlying rocks.

\section{Summary of Simulation Scenarios for Well CPU-9}

Under baseline conditions, the zones of transport to CPU-9 extend laterally to the east, generally following the trend in the hydraulic gradient within the Troutdale gravel and unconsolidated sedimentary aquifers. Time of travel estimates suggest that most of the ground water that discharges from well CPU-9 had recharged the Troutdale gravel and unconsolidated sedimentary aquifers within 50 years. Analysis of the pathlines also suggests that well CPU-9 captures some ground water older than 50 years that would otherwise discharge to the creek. An important source of water to well CPU-9 was recharge from induced infiltration from Salmon Creek. Depending on the difference in the quality of ground water and surface water at the well site, water from the creek could alter the quality of water discharged from the well.

Uncertainty in the porosity of the Troutdale gravel aquifer and the unconsolidated sedimentary aquifer contributed more to the uncertainty in delineating the zones of transport for well CPU-9 than did uncertainty in other factors. Changing the porosity by factors of 0.8 and 1.2 produced the greatest change in the area of the zones delineated for this well. The magnitude of these changes indicates that intermediate and regional ground-water flow systems contribute a significant amount of the ground water discharging from the well.

Increasing the discharge of well CPU-9 did not significantly expand the total area enclosed by the zones of transport for well CPU-9 from the baseline conditions; however, pumping of well CPU-9 did induce more infiltration from Salmon Creek. The significance of abundant ground-water discharge to Salmon Creek and the high rate of recharge from underlying cells into the selected group of cells indicates that intermediate and regional ground-water flow systems which would otherwise discharge to Salmon Creek are important sources of water to well CPU-9. 
Uncertainty in the withdrawal rates of nearby wells could have an important effect on the zones of transport delineated for well CPU-9. Excluding all discharge from other wells produced the greatest change in the simulated water budget and in the total area enclosed by the zones of transport for well CPU-9 relative to the baseline simulation. Under baseline conditions, the discharge from wells near well CPU-9, especially southeast of the well site, affects the principal direction of ground-water flow and the hydraulic gradient.

\section{City of Vancouver Well 9.6}

The city of Vancouver is located in the southern part of the study area near the Columbia River (fig. 1). City of Vancouver Well 9.6 (CV-9.6) is part of well station 9; five wells at this station supply the municipal water system for the city of Vancouver. Well CV-9.6 discharges approximately 1,300 gallons per minute $\left(2.9 \mathrm{ft}^{3} / \mathrm{s}\right)$.

\section{Local Hydrogeologic Setting}

Well CV-9.6 discharges from the Troutdale gravel aquifer, which was simulated by the two uppermost layers in the Portland Basin model. The Troutdale gravel aquifer is approximately $250 \mathrm{ft}$ thick and overlies approximately $100 \mathrm{ft}$ of confining unit 1 , which was simulated by layer 3 . The Troutdale sandstone aquifer, which underlies confining unit 1 , is approximately $150 \mathrm{ft}$ thick and was simulated by layer 4. Approximately $975 \mathrm{ft}$ of confining unit 2 underlies the Troutdale sandstone aquifer and was simulated by layers 4 through 7 . Older rocks underlie confining unit 2 and were simulated by layer 8 . The unconsolidated sedimentary aquifer crops out west of Lacamas Creek in many of the cells in layer 1. Well CV-9.6 is located in row 42, column 29 of the Portland Basin model grid (fig. 17).

The simulated distributions of well discharge, recharge, and stream leakage in layers 1 and 2 of the Portland Basin model for a selected group of 80 cells in each layer surrounding well CV-9.6 are shown in figure 17. Well discharge for this group of cells containing wells ranges from 0.04 to $7.23 \mathrm{ft}^{3} / \mathrm{s}$. For the cell containing well CV-9.6, withdrawals by other wells at well station 9 accounted for $4.33 \mathrm{ft}^{3} / \mathrm{s}$ of the well discharge. Areal recharge in the selected cells ranges from 0.29 to 0.92 cubic $\mathrm{ft}^{3} / \mathrm{s}$. Simulated stream leakage ranges from -1.72 to $1.22 \mathrm{ft}^{3} / \mathrm{s}$ for cells representing Burnt Bridge and Lacamas Creeks.
Induced recharge from Burnt Bridge and Lacamas Creeks has the potential to alter the quality of the water discharging from well CV-9.6 if the quality of the water in the stream is different from the quality of the ground water in the vicinity of the well.

The local simulated transmissivity of model layers 1 and 2 ranges from 670 to $18,200 \mathrm{ft}^{2} / \mathrm{d}$ across the selected group of cells (fig. 17). The variation in transmissivity relates to changes in the presence of Troutdale gravel and unconsolidated sedimentary aquifers and thickness and hydraulic conductivity within these aquifers in cells of layers 1 and 2 . The transmissivity of cells representing the Troutdale gravel aquifer ranges from 670 to $15,240 \mathrm{ft}^{2} / \mathrm{d}$ in the vicinity of well CV-9.6. The transmissivity of cells representing the unconsolidated sedimentary aquifer ranges from 1,075 to $10,150 \mathrm{ft}^{2} / \mathrm{d}$. The local porosity distribution is relatively homogeneous, ranging from 0.23 to 0.31 in both aquifers.

\section{Zones of Transport and Simulated Water Budget for the Baseline Simulation}

The zones of transport for well CV-9.6 were delineated by tracking particles along pathlines in the reverse direction of ground-water flow from two superposed cells in layers 1 and 2 at row 42, column 29 . The reverse-direction pathlines of these particles were to the north in the upgradient direction, approximately perpendicular to lines of equal simulated hydraulic head in the unconsolidated sedimentary and Troutdale gravel aquifers (fig. 18).

Particle pathlines indicated that most of the water that discharges from well CV-9.6 had recharged the Troutdale gravel and the unconsolidated sedimentary aquifers within 50 years. Analysis of the pathlines also suggests that about 40 percent of CV-9.6's discharge is older than 50 years and flows through the underlying confining unit 1 from recharge areas north of the well.

The simulated water budget for the selected group of cells is listed in table 12. Recharge from precipitation, on-site waste-disposal systems, and drywells supplied 87 percent of the total inflow in the baseline simulation, ground water flowing into this group of cells from surrounding cells in layers 1 and 2 (inflow, side faces) provided 11 percent, induced infiltration from Lacamas and Burnt Bridge Creeks (inflow, streams) contributed 3 percent, and ground water flowing into this block of cells from underlying cells from model layer 3 (inflow, bottom face) provided less than 1 percent. 
WELL DISCHARGE
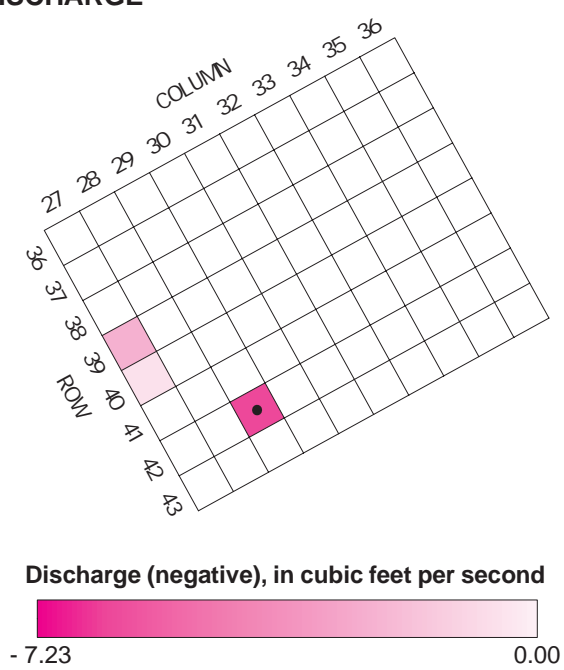

RECHARGE

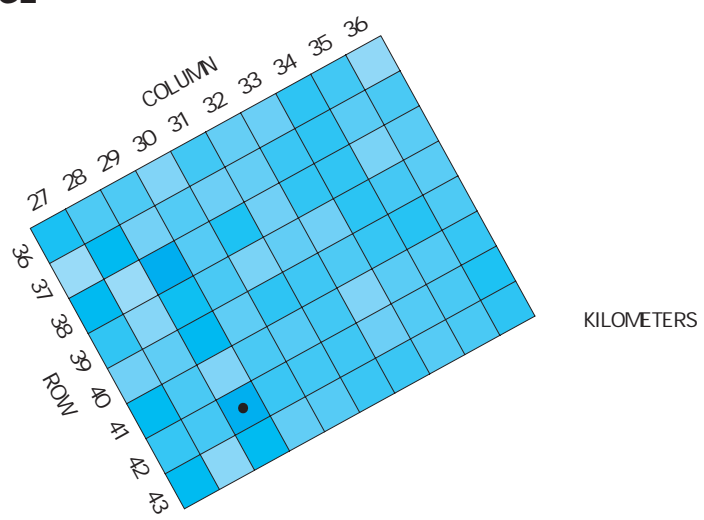

Recharge (positive), in cubic feet per second

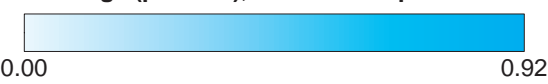

RIVER AND STREAM LEAKAGE

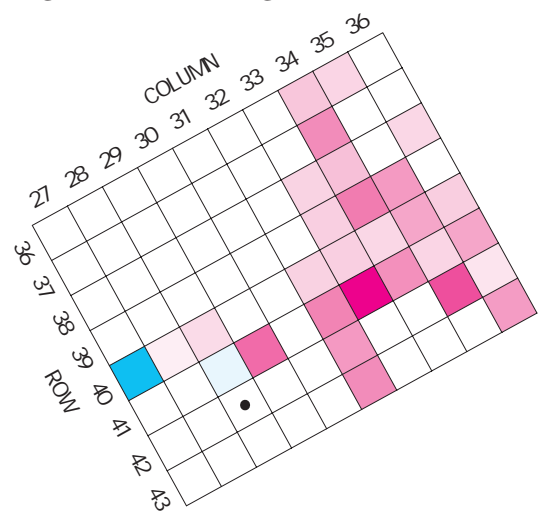

Discharge (negative) or recharge (positive), in cubic feet per second

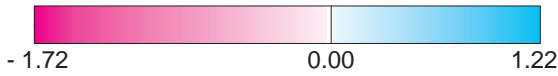

TRANSMISSIVITY
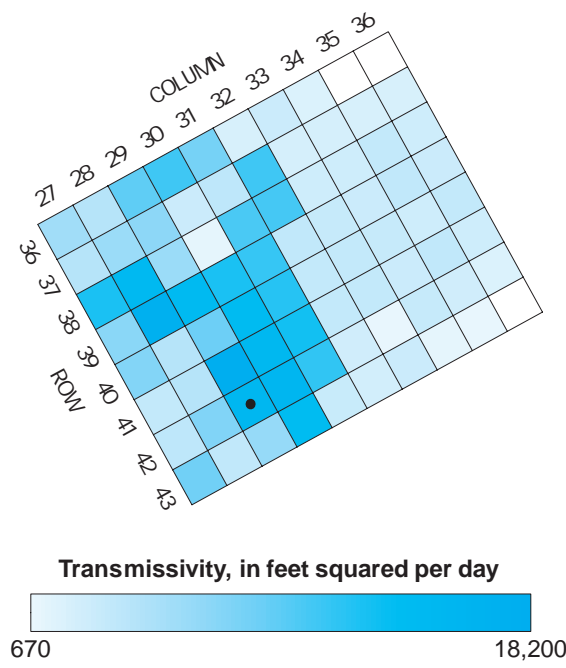

POROSITY
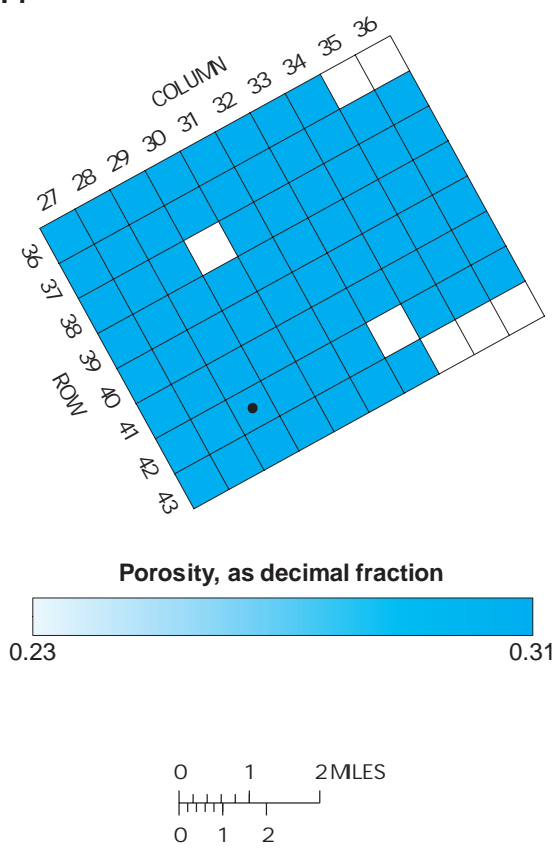

EXPLANATION

- Well CV9. 6

Figure 17. Simulated baseline conditions in layers 1 and 2, near well CV-9.6. (Source: Morgan and McFarland, 1996.) 


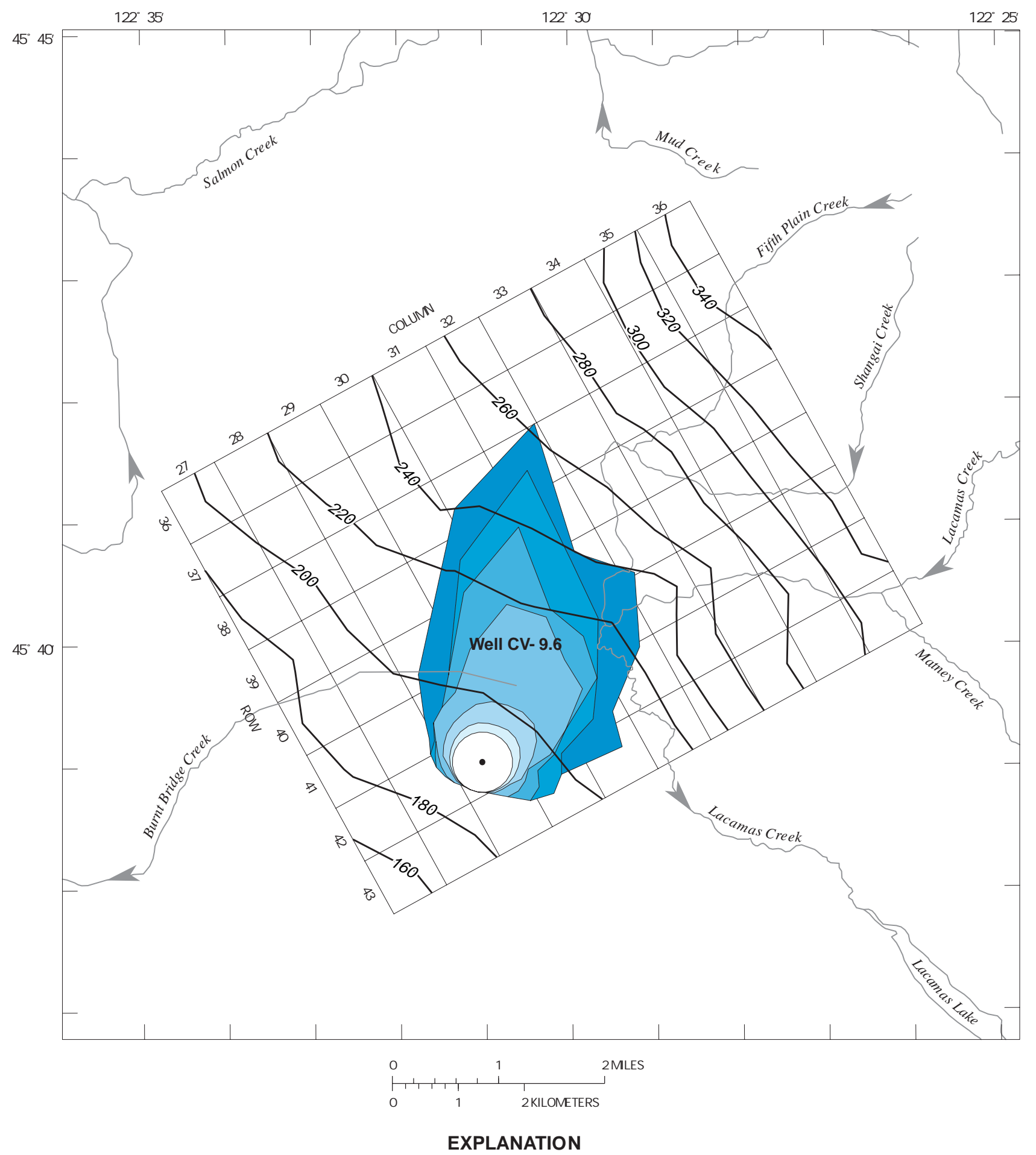

Zones of transport-value indicates time of travel in years.

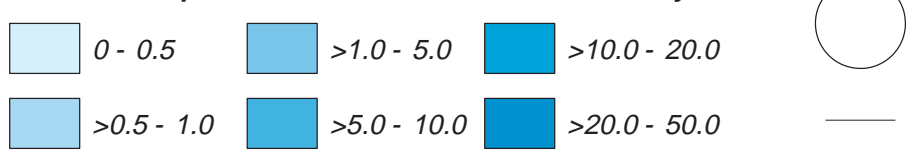

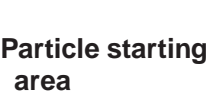

Model grid boundary

Figure 18. Projected zones of transport for well CV-9.6, under baseline conditions (>, greater than; <, less than; =, equal to). The direction of streamflow in Lacamas Creek is from north to south, and flow in Burnt Bridge Creek is from east to west. 
Table 12. Simulated water budget in a selected group of cells in layers 1 and 2 surrounding well CV-9.6, under different hydrologic conditions [> less than]

\begin{tabular}{|c|c|c|c|c|c|c|}
\hline \multirow{2}{*}{\multicolumn{2}{|c|}{$\begin{array}{c}\text { Hydrologic source } \\
\text { or sink } \\
\text { or cell face }\end{array}$}} & \multirow{2}{*}{$\begin{array}{c}\text { Baseline } \\
\text { flow } \\
\text { rate }^{1} \\
\end{array}$} & Increased-discharge & No-interference & Increased-conductivity & Decreased-conductivity \\
\hline & & & Percent change ${ }^{2}$ & Percent change $^{2}$ & Percent change 2 & Percent change ${ }^{2}$ \\
\hline \multirow{8}{*}{$\frac{30}{\underline{\underline{c}}}$} & Recharge & 41.2 & 0.0 & 0.0 & 0.0 & 0.0 \\
\hline & Drains & 0 & 0 & 0 & 0 & 0 \\
\hline & Rivers & 0 & 0 & 0 & 0 & 0 \\
\hline & Streams & 1.3 & -25.4 & -100.0 & -77.0 & -94.4 \\
\hline & Side faces & 5.1 & 1.2 & -1.8 & 13.0 & -7.1 \\
\hline & Top face & 0 & 0 & 0 & 0 & 0 \\
\hline & Bottom face & $<.1$ & 100.0 & -33.3 & 0 & 166.7 \\
\hline & Total or net & 47.6 & -.5 & -2.8 & -.6 & -3.2 \\
\hline \multirow{11}{*}{$\frac{3}{\frac{3}{E}}$} & Recharge & 0 & 0 & 0 & 0 & 0 \\
\hline & Drains & 0 & 0 & 0 & 0 & 0 \\
\hline & Rivers & 0 & 0 & 0 & 0 & 0 \\
\hline & Streams & 16.9 & -5.1 & 34.2 & -22.2 & 22.9 \\
\hline & Wells & 11.2 & 13.3 & -73.5 & 0 & 0 \\
\hline & Side faces & 13.6 & -5.5 & 7.6 & 18.1 & -31.5 \\
\hline & Top face & 0 & 0 & 0 & 0 & 0 \\
\hline & Bottom face & 5.9 & -2.0 & 1.4 & 16.5 & -18.2 \\
\hline & Total or net & 47.6 & -.5 & -2.8 & -.6 & -3.2 \\
\hline & Area $^{3}$ & 4,119 & 15.7 & -10.6 & 41.0 & -4.2 \\
\hline & Hydraulic head ${ }^{4}$ & --- & -2 & 10 & -9 & 10 \\
\hline & \multicolumn{6}{|c|}{$\begin{array}{l}\text { Value of the area enclosed by the zones of transport ( } 50 \text { year time of travel) from table } 13 \text { for baseline simulation (in square feet times } 10^{4} \text { ), } \\
\text { values for the remaining simulations are the percent change in cumulative area taken from table } 13 \text {. }\end{array}$} \\
\hline
\end{tabular}

The model simulated recharge from induced infiltration from Burnt Bridge and Lacamas Creeks into the unconsolidated sedimentary and Troutdale gravel aquifers in 2 stream cells adjacent to the well CV-9.6; in 28 other stream cells, the model simulated groundwater discharge to the stream.

Simulated ground-water discharge from cells to Burnt Bridge and Lacamas Creeks (outflow, streams) accounted for 36 percent of the total outflow, discharge of ground water from this group of cells to adjacent cells in layers 1 and 2 (outflow, side faces) accounted for 29 percent, discharge from wells (outflow, wells) accounted for 24 percent, and discharge to underlying cells in layer 3 (outflow, bottom face) accounted for 12 percent.

The size and shape of the zones of transport were influenced by several factors. The shape of the zones of transport were primarily influenced by spatial variation in transmissivity and the direction of groundwater gradient. The recharge distribution was not an important factor in shaping the zones of transport; however, the magnitude of recharge affects the extent of each zone. The zones of transport for CV-9.6 are elongated northward, in the direction of the regional hydraulic gradient (fig. 18). The zones of transport are highly asymmetrical due largely to the variability of the transmissivity in the unconsolidated sedimentary and Troutdale gravel aquifers. The northern extent of the zones of transport is aligned with a zone of high transmissivity that extends from CV-9.6 northward (fig. 17). To a lesser extent the shape of the zones of transport were influenced the pumping rate of well CV-9.6, which caused convergent flow paths near well CV-9.6 that resulted in the fan-shaped zones of transport oriented to the north. 


\section{Zones of Transport and Simulated Water Budget for the Increased-Discharge Simulation}

Increasing the discharge rate of well CV-9.6 by a factor 1.5 caused changes in the direction of groundwater flow and in the ground-water gradient that affected the size and shape of the zones of transport. The total area enclosed by the zones of transport was enlarged by nearly 16 percent from the baseline simulation (fig. 19, table 13). Particle pathlines and time of travel estimates suggest that under increased-discharge conditions, more upward flow through confining unit 1 occurs. The cone of depression extended farther, hence expanded the zones, to capture more discharge to meet the increased discharge rate of well CV-9.6 and compensate for the reduction in recharge from induced infiltration from Burnt Bridge Creek (table 12). Simulated ground-water levels declined by an average of about $2 \mathrm{ft}$ in the Troutdale gravel and the unconsolidated sedimentary aquifers near the well, and by $7 \mathrm{ft}$ at well CV-9.6. In the gaining reaches of Burnt Bridge Creek, the gradient between ground-water levels and streams was less, thereby reducing groundwater discharge and subsequently baseflow by nearly 50 percent. Consequently, less streamflow was available for inducement by pumping of well CV-9.6, and downstream of the well Burnt Bridge Creek went dry.

\section{Zones of Transport and Simulated Water Budget for the No-Interference Simulation}

When all well discharge other than that of well CV-9.6 was excluded from the model, the total area enclosed by the zones of transport increased by approximately 11 percent (fig. 19, table 13). Particle pathlines and time of travel estimates suggest that most of the water that discharged from well CV-9.6 recharged the Troutdale gravel and unconsolidated sedimentary aquifers within 50 years with the removal of interfering wells. The narrower zones of transport relative to those from the baseline simulation indicate that ground-water flow paths converge less with the removal of other wells. With the removal of other wells, well CV-9.6 was able to capture more of the discharge from nearby streams, thus reducing the size of the zones of transport and the proportion of ground water that moved upward through confining unit 1.

With the removal of other wells, simulated ground-water levels in Troutdale gravel aquifer and the unconsolidated sedimentary aquifer near the well rose from baseline conditions by an average of $10 \mathrm{ft}$ (table 12) and by $26 \mathrm{ft}$ at the well. Induced infiltration from streams was zero when the discharge of other wells was removed, and the discharge of ground water to Burnt Bridge and Lacamas Creeks increased by nearly 35 percent.

\section{Zones of Transport for Increased-Porosity and Decreased-Porosity Simulations}

Under increased- and decreased-porosity conditions, the size and shape of the zones of transport delineated for well CV-9.6 differed significantly from those in from the baseline simulation (fig. 19). The total area enclosed by the zones of transport decreased by about 19 percent under increased-porosity conditions and increased 80 percent under decreasedporosity conditions.

For increased porosity values, the zones did not extend as far from well CV-9.6 because ground water moves to the well more slowly than under baseline conditions. The areas of the zones of transport for all times of travel were reduced. For decreased porosity values, the zones extended farther from well CV-9.6 because ground water moves to the well more rapidly than under baseline conditions. The areas of the zones of transport for all times of travel increased, especially for the 20 to 50 year period. The magnitude of these changes in the size of each zone indicates that intermediate and regional ground-water flow systems contribute a significant amount of the ground water discharging from the well.

\section{Zones of Transport and Simulated Water Budget for the Increased-Conductivity and Decreased-Conductivity Simulations}

Varying the horizontal hydraulic conductivity from the baseline simulation caused significant changes in the direction of ground-water flow, the hydraulic gradient, and in the water budget. Under increased-conductivity conditions, more of the discharge of CV-9.6 flows through the lower part of the Troutdale gravel aquifer and confining unit 1 than under baseline conditions. Also, much more of the water that discharges from the well reaches the well in less than 50 years than under baseline conditions. Simulated ground-water levels declined by an average of about $9 \mathrm{ft}$ in the Troutdale gravel aquifer and the unconsolidated sedimentary aquifer near the well (table 12) and by about $6 \mathrm{ft}$ at well CV-9.6. With declining water levels, the model simulated less ground-water discharge to Burnt Bridge Creek than under baseline conditions, and, therefore, less streamflow was available for induced recharge (table 12). 
INCREASED DISCHARGE

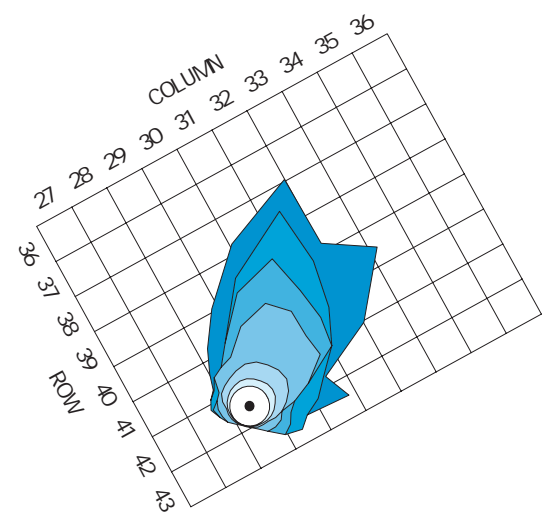

INCREASED POROSITY

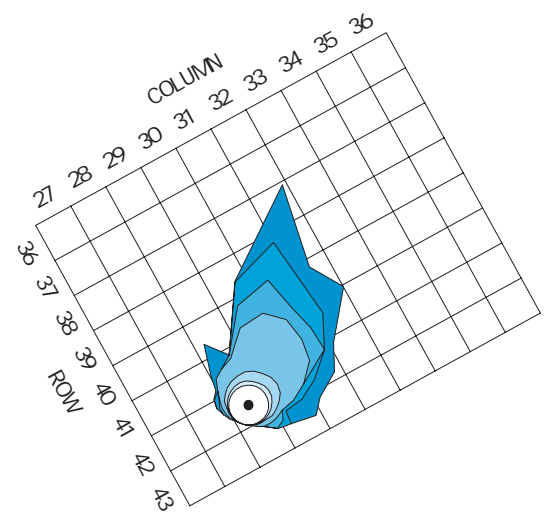

KILOMETERS

\section{INCREASED CONDUCTIVITY}

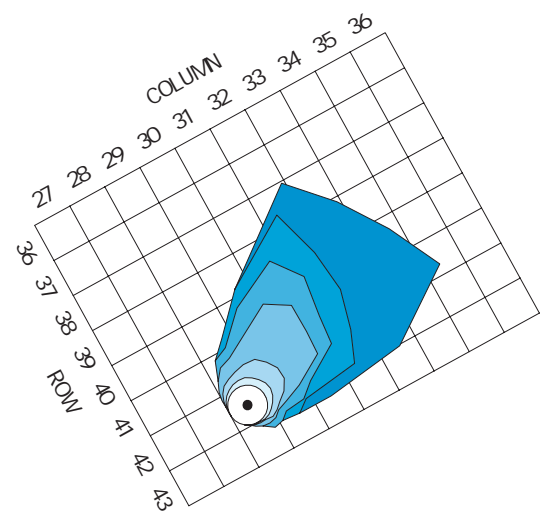

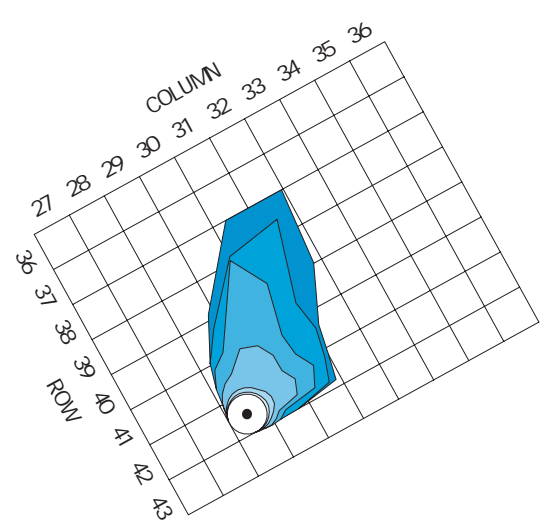

DECREASED POROSITY

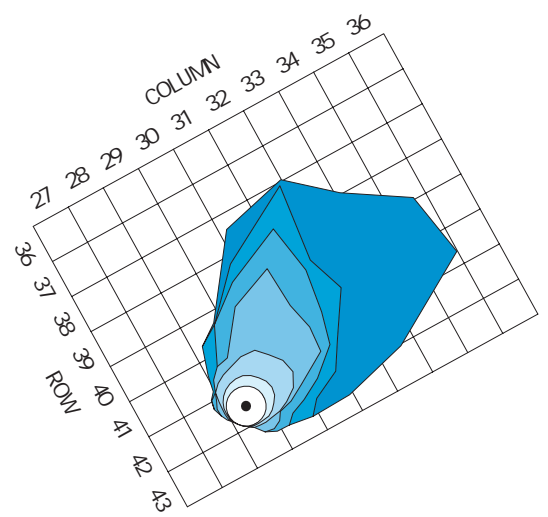

DECREASED CONDUCTIVITY

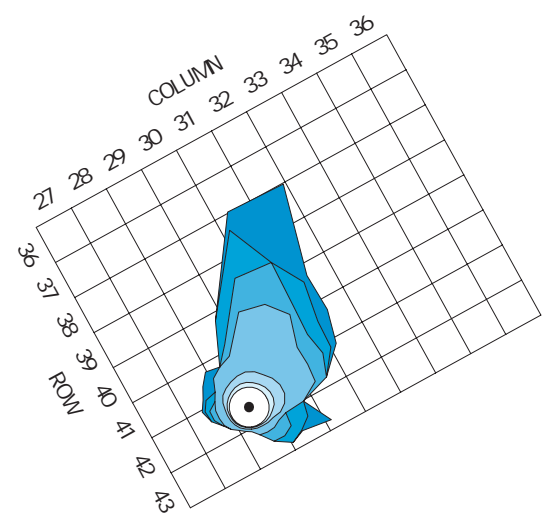

EXPLANATION

Zones of transport-value indicates time of travel in years.

$\square=0.5 \square>1.0-5.0 \square>10.0-20.0$
$\square>0.5-1.0 \square>5.0-10.0 \square>20.0-50.0$

Particle starting area

Model cell boundary

- Well CV- 9.6

Figure 19. Projected zones of transport for well CV-9.6, under different simulated hydrologic conditions (>, greater than; <, less than; =, equal to). 
Table 13. Areas of projected zones of transport from different simulations for well CV-9.6

\begin{tabular}{|c|c|c|c|c|c|c|c|c|c|c|c|c|c|c|}
\hline \multirow[b]{3}{*}{$\begin{array}{c}\text { Time } \\
\text { (years) }\end{array}$} & \multicolumn{2}{|c|}{ Baseline } & \multicolumn{2}{|c|}{ Increased-discharge } & \multicolumn{2}{|c|}{ No-Interference } & \multicolumn{2}{|c|}{ Increased-porosity } & \multicolumn{2}{|c|}{ Decreased-porosity } & \multicolumn{2}{|c|}{ Increased-conductivity } & \multicolumn{2}{|c|}{ Decreased-conductivity } \\
\hline & & & Perc & ent change & Perc & nt change & Perce & nt change & Perce & nt change & Perce & ent change & Perc & nt change \\
\hline & Area $^{1}$ & $\begin{array}{l}\text { Cumulative } \\
\text { area }^{2}\end{array}$ & Area $^{3}$ & $\begin{array}{l}\text { Cumulative } \\
\text { area }^{4}\end{array}$ & Area $^{3}$ & $\begin{array}{l}\text { Cumulative } \\
\text { area }^{4}\end{array}$ & Area $^{3}$ & $\begin{array}{c}\text { Cumulative } \\
\text { area }^{4}\end{array}$ & Area $^{3}$ & $\begin{array}{l}\text { Cumulative } \\
\text { area }^{4}\end{array}$ & Area $^{3}$ & $\begin{array}{c}\text { Cumulative } \\
\text { area }^{4}\end{array}$ & Area $^{3}$ & $\begin{array}{l}\text { Cumulative } \\
\text { area }^{4}\end{array}$ \\
\hline 0.5 & 77 & 290 & 24.3 & 6.4 & -67.0 & -17.7 & -32.8 & -8.7 & 77.9 & 20.6 & 10.8 & 2.9 & -9.1 & -2.4 \\
\hline 1 & 197 & 487 & 26.9 & 14.7 & -69.1 & -38.5 & -33.4 & -18.7 & 93.8 & 50.2 & 11.3 & 6.3 & -10.0 & -5.5 \\
\hline 5 & 896 & 1,383 & 3.8 & 7.7 & -48.0 & -44.6 & -3.8 & -9.0 & 17.6 & 29.1 & -8.2 & -3.1 & 16.5 & 10.7 \\
\hline 10 & 645 & 2,028 & 14.9 & 10.0 & 51.1 & -14.2 & -31.4 & -16.2 & 54.3 & 37.1 & 25.8 & 6.1 & 6.5 & 9.4 \\
\hline 20 & 767 & 2,795 & 11.2 & 10.3 & 32.4 & -1.4 & -17.7 & -16.6 & 26.0 & 34.1 & 45.6 & 16.9 & -1.7 & 6.3 \\
\hline 50 & 1,324 & 4,119 & -27.2 & 15.7 & -30.0 & -10.6 & -24.2 & -19.0 & 178.2 & 80.4 & 92.0 & 41.0 & -26.5 & -4.2 \\
\hline
\end{tabular}

1 The area of the projected zones of transport for each selected time of travel for the baseline simulation, (in square feet times $10^{-4}$ ).

2 Summation of areas for this and all previous time steps for the baseline simulation, including the starting area, (in square feet times $10^{-4}$ ).

3 Percent change in area is the area for a simulation minus the area for the baseline simulation divided by the area for the baseline simulation.

4 Percent change in cumulative area is the cumulative area of a simulation minus the area of the baseline simulation divided by the area of the baseline simulation. 
The asymmetry that was evident in the shape of the zones of transport under baseline conditions was less pronounced under increased-conductivity conditions, indicating that ground-water flow paths to the well converge less (fig. 19). To compensate for the loss of induced infiltration to well CV-9.6, the zones of transport expanded to capture discharge from other areas, resulting in a 41 percent increase in the total area enclosed by the zones (table 13).

Under decreased-conductivity conditions, nearly as much of the discharge of CV-9.6 flows through the lower part of the Troutdale gravel aquifer as under baseline conditions; however, more of the discharge flows through confining unit 1 . Even more of the water that discharges from the well reaches the well in less than 50 years than under baseline conditions. Simulated water levels rose by an average of $10 \mathrm{ft}$ in the Troutdale gravel aquifer and unconsolidated sedimentary aquifer near the well (table 12) and by approximately $5 \mathrm{ft}$ at well CV-9.6. With the rise in water levels, the model simulated nearly 23 percent more ground-water discharge to Burnt Bridge Creek than under baseline conditions, and, therefore, more streamflow was available for induced recharge. However, the discharge rate of well CV-9.6 was inadequate to sufficiently draw down groundwater levels within nearby streams reaches to induce infiltration from Burnt Bridge Creek to the well, causing near complete loss of induced infiltration into losing reaches. The asymmetry that was evident in the shape of the zones of transport under baseline conditions was more pronounced under decreasedconductivity conditions, indicating that ground-water flow paths to the well converged more (fig. 19). To compensate for the loss of induced infiltration to well CV-9.6 under decreased-conductivity conditions, the zones of transport extended downward in confining unit 1 to capture discharge from more distant streams, resulting in about 5 percent decrease in the total area enclosed by the zones (table 13).

\section{Summary of Simulation Scenarios for Well CV-9.6}

Under baseline conditions, the zones of transport to CV-9.6 extend laterally to the north and northeast, generally following the hydraulic gradient within the unconsolidated sedimentary and Troutdale gravel aquifers. The zones of transport for well CV-9.6 were delineated for times of travel up to 50 years. Results of the particle-tracking analysis from the baseline simulation indicate that most of the water that discharges from well CV-9.6 had recharged the Troutdale gravel aquifer and the unconsolidated sedimentary aquifer within 50 years. The principal factor influencing the fan-shaped zones of transport is the convergent flow paths to well CV-9.6.

Uncertainty in the porosity of the unconsolidated sedimentary and Troutdale gravel aquifers contributed more to the uncertainty in delineating the zones of transport for CV-9.6 than did uncertainty in other factors. Uncertainty in other factors, such as well discharge rate and horizontal hydraulic conductivity, had measurable effects on the zones of transport, but errors introduced through these factors were less significant. The magnitude of the changes in the size of each zone indicates that intermediate and regional ground-water flow systems contribute a significant amount of the ground water discharging from the well.

Excluding discharge from other wells produced large changes in the simulated water budget and a large reduction in the total area of the zones of transport, showing that the discharge from wells near well CV-9.6 affected the direction of ground-water flow and the hydraulic gradient under baseline conditions. Particle pathlines and time of travel estimates suggest that if nearby wells were inactive, much more of the water discharging from well CV-9.6 would be younger relative to the baseline simulation.

Changing the horizontal hydraulic conductivity by multiplying by 0.8 and 1.2 produced large changes in the ground-water levels and hydraulic gradient in the vicinity of well CV-9.6; in fact, these alterations move the flow model out of calibration, but are useful for estimating the effects of uncertainty in this factor. Under increased-conductivity conditions, ground water moves to the well more rapidly through the system, and the zones of transport are larger for the same times of travel. Particle pathlines and time of travel estimates indicated that the same amount of ground water that discharges from well CPU-19 recharges the unconsolidated sedimentary and Troutdale gravel aquifers within 50 years as under baseline conditions; however, more of the discharge flowed through confining unit 1.

\section{City of Vancouver Ellsworth Deep Well}

City of Vancouver Ellsworth Deep Well (CV-ED) was a proposed well at the time of this study (fig. 1). This well has since been completed and will be part of the municipal system of the city of Vancouver by the year 2000 (Swanson, 1992). At the time of this study, the anticipated discharge of CV-ED was 2,100 gallons per minute $\left(4.7 \mathrm{ft}^{3} / \mathrm{s}\right)$. 


\section{Local Hydrogeologic Setting}

When well CV-ED was completed, it was discovered that the sand and gravel aquifer extends farther north than was indicated by well data available when Swanson and others (1993) mapped the hydrogeologic units in the basin. Well CV-ED discharges from the sand and gravel aquifer; however, because the Portland Basin model was developed on the basis of mapping by Swanson and others (1993), the sand and gravel aquifer is not present in the model at well CV-ED, and discharge was simulated from confining unit 2. Confining unit 2 is approximately $1,050 \mathrm{ft}$ thick at this site and was simulated by layers 5 through 7 in the model. The Troutdale sandstone aquifer, approximately $75 \mathrm{ft}$ thick, overlies confining unit 2, and was simulated by layer 4 . Confining unit 1 , approximately $125 \mathrm{ft}$ thick, overlies the Troutdale sandstone aquifer and was simulated by layer 3 . The Troutdale gravel aquifer, approximately $350 \mathrm{ft}$ thick, overlies confining unit 1 and was simulated by the two uppermost layers. Older rocks underlie confining unit 2 and were simulated by layer 8 . The extent and thickness of these hydrogeologic units varies considerably in the vicinity of well CV-ED. Well CV-ED is located in row 44 and column 23 of the Portland Basin model grid (fig. 20)

The simulated distributions of well discharge, recharge, and stream leakage in layers 5 through 7 of the Portland Basin model for a selected group of 64 cells in each layer surrounding well CV-ED are shown in figure 20. Well discharge shown for this group of cells represents only discharge from well CV-ED from confining unit 2. Local simulated recharge and stream leakage are absent in figure 20 because water derived from these sources must pass through model layers 1 through 4. Cells overlying the selected group of cells (layers 1 through 4) receive recharge by infiltration from precipitation and from drywells into the groundwater system and from induced infiltration from streams.

The local simulated transmissivity of model layers 5 through 7 ranges from about 1,000 to $13,200 \mathrm{ft}^{2} / \mathrm{d}$ across the selected group of cells, with values of transmissivity decreasing from south to north (fig. 20). The variation in transmissivity relates to variations in thickness and hydraulic conductivity of confining unit 2 , the undifferentiated fine-grained deposits, and the sand and gravel aquifer in cells of layers 5 through 7 . The transmissivity of cells representing the confining unit 2 ranges from about 50 to $3,300 \mathrm{ft}^{2} / \mathrm{d}$ in the vicinity of well CV-ED. The trans- missivity of cells representing the undifferentiated fine-grained deposits ranges from about 1,400 to $4,200 \mathrm{ft}^{2} / \mathrm{d}$ in the vicinity of well CV-ED. The transmissivity of cells representing the sand and gravel aquifer ranges from about 5,200 to $13,000 \mathrm{ft}^{2} / \mathrm{d}$ in the vicinity of well CV-ED.

Simulated porosity in cells in layers 5 through 7 ranges from 0.14 to 0.31 because of the distribution of the different hydrogeologic units (fig. 20). Porosity values decrease from south to north.

\section{The Effect of Well CV-ED}

on Simulated Water Levels and Water Budget

Because well CV-ED was not simulated in the original Portland Basin model, it was added to the model to make the baseline simulation for this well. Adding the discharge of well CV-ED to the baseline conditions caused simulated ground-water levels in the selected group of cells in confining unit 2 (layers 5 through 7) to decline. The average of the declines increased with depth, from about $12 \mathrm{ft}$ in layer 5 to about $23 \mathrm{ft}$ in layer 7 . Simulated water levels in the cell containing the well CV-ED declined by about $60 \mathrm{ft}$ in layer 5 and $82 \mathrm{ft}$ in layer 7.

The inclusion of well CV-ED altered the water budget in the selected group of cells. Under original conditions, inflow from adjacent cells in layers 5 through 7 provided 90 percent of the total inflow to the selected group of cells (table 14). Under baseline conditions, the total inflow to the selected group of cells nearly doubled. Inflow from adjacent cells in layers 5 through 7 provided less of the total inflow, because inflow from the overlying Troutdale sandstone aquifer and underlying older rocks provided a greater proportion of water. Under original conditions, discharge from the selected group of cells was principally to adjacent aquifers and the confining unit 2 (layers 5 through 7). Under baseline conditions, discharge from the selected group of cells was reduced by nearly 65 percent to the surrounding aquifers (top and bottom faces) and confining unit 2 (side faces).

Adding the discharge of well CV-ED to the model affected the simulated ground-water levels and water budget in the overlying aquifers and confining unit 1. For example, simulated ground-water levels in the unconsolidated sediments (layer 1) generally declined by less than 1 foot from baseline conditions; however, declines of greater than 1 foot occurred in stream cells representing Burnt Bridge Creek. The model simulated less induced infiltration because available streamflow in Burnt Bridge Creek decreased 
WELL DISCHARGE
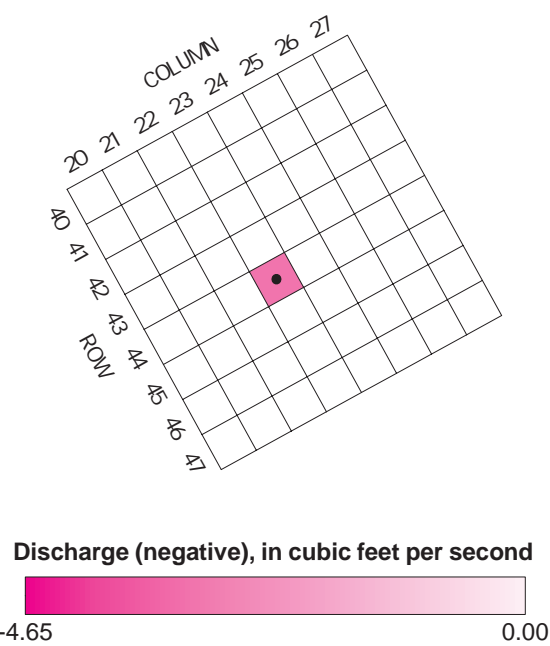

RECHARGE

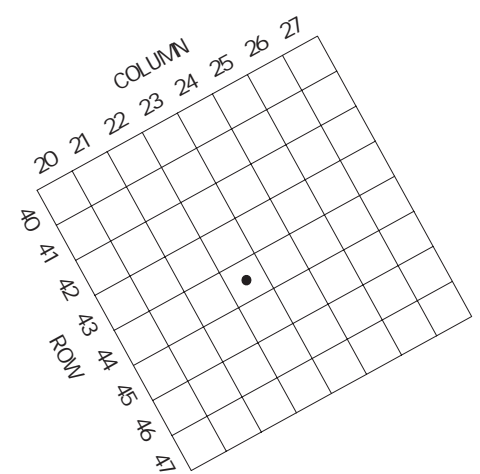

Recharge (positive), in cubic feet per second 0.00

\section{RIVER AND STREAM LEAKAGE}

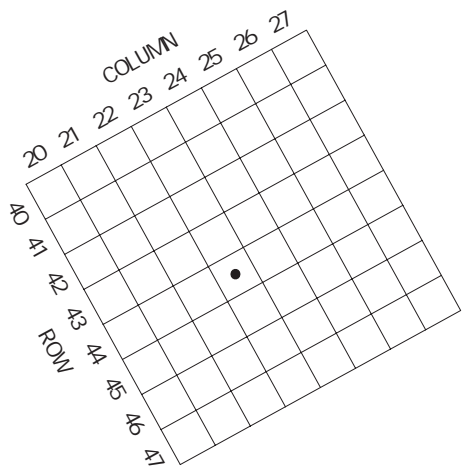

TRANSMISSIVITY
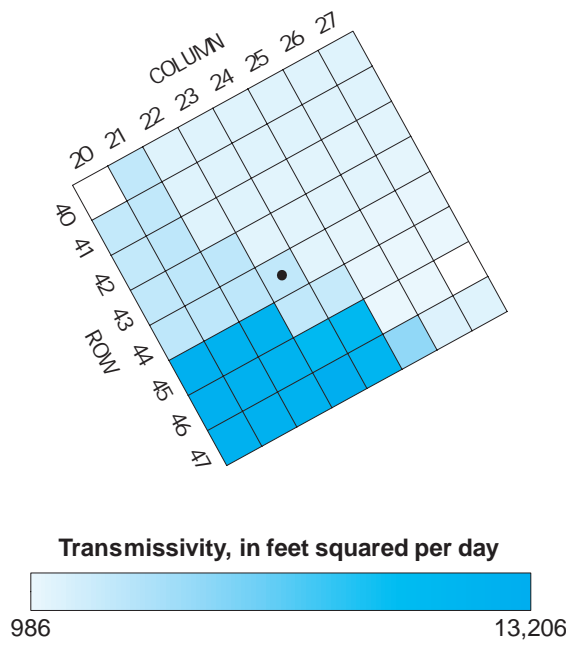

POROSITY
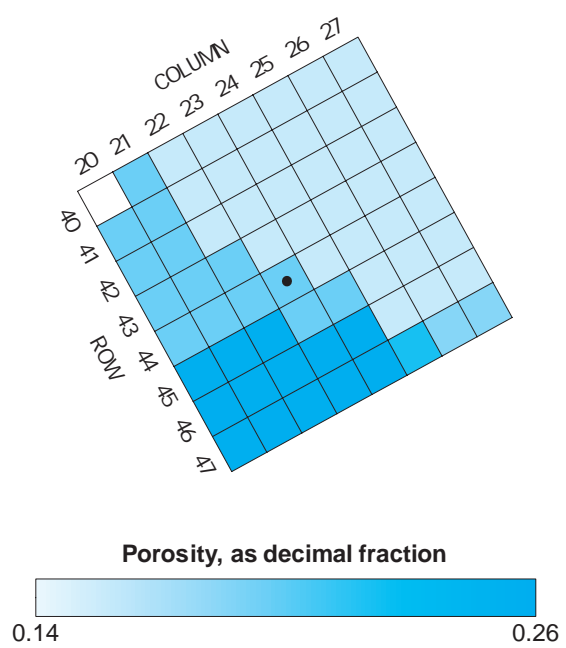

Discharge (negative) or recharge (positive), in cubic feet per second

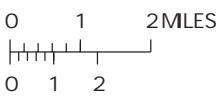

EXPLANATION

- Well CVED

Figure 20. Simulated baseline conditions in layers 5 through 7, near well CV-ED. (Source: Morgan and McFarland, 1996.) 
Table 14. Simulated water budget in a selected group of cells in layers 5 through 7 surrounding well CV-ED, under different hydrologic conditions [> less than]

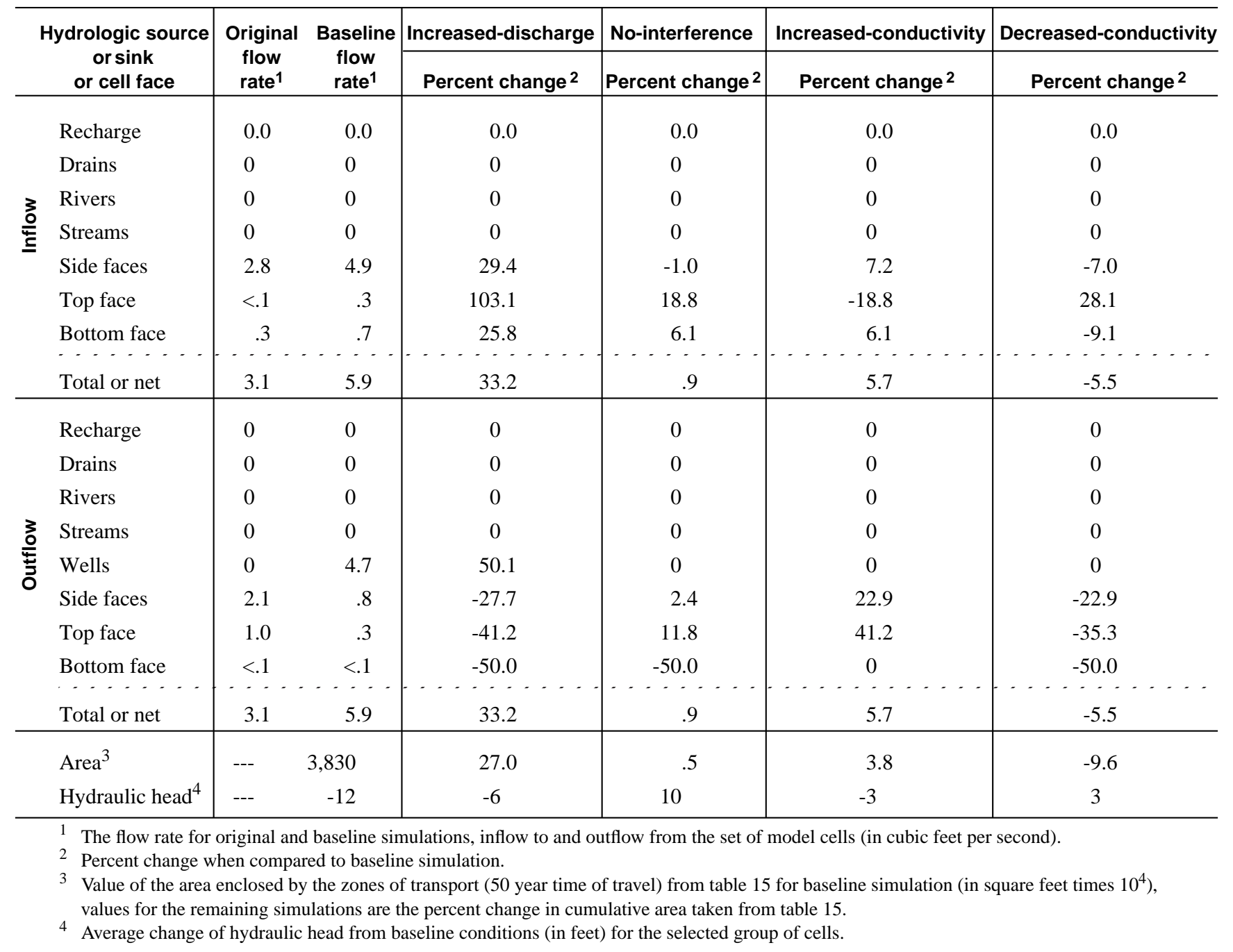

With the addition of well CV-ED, discharge to the Columbia River was reduced because discharge to the overlying Troutdale sandstone aquifer (layer 4) from the selected group of cells was reduced by 70 percent relative to baseline conditions. Pumping of well CV-ED diverts ground water from intermediate or regional ground-water flow systems that would discharge to overlying cells and hence discharge to the Columbia River.

\section{Zones of Transport} for the Proposed-Condition Simulation

The zones of transport for well CV-ED were delineated by tracking particles along pathlines in the reverse direction of ground-water flow from three superposed cells in layers 5 through 7 at row 44 , column 23. The reverse-direction pathlines of these particles were to the north, approximately perpendicu- lar to lines of equal simulated hydraulic head in confining unit 1 and the undifferentiated fine-grained deposits (fig. 21).

Particle pathlines south of the well, toward the Columbia River, indicated that most of the water from the south that discharged from well CV-ED passed through confining unit 2 and the sand and gravel aquifer (layers 5 through 7). Particle pathlines north of the well indicated that most of the water from the north that discharged from well CV-ED passed through the overlying Troutdale sandstone aquifer (layer 4). Time of travel estimates suggest that all of the ground water discharging from well CV-ED was older than 50 years.

The size and shape of the zones of transport shown in figure 21 were influenced by several factors. Because well CV-ED discharged from cells in layers 5 through 7, the only source of recharge to the selected group of cells was from the inflow of ground water. 


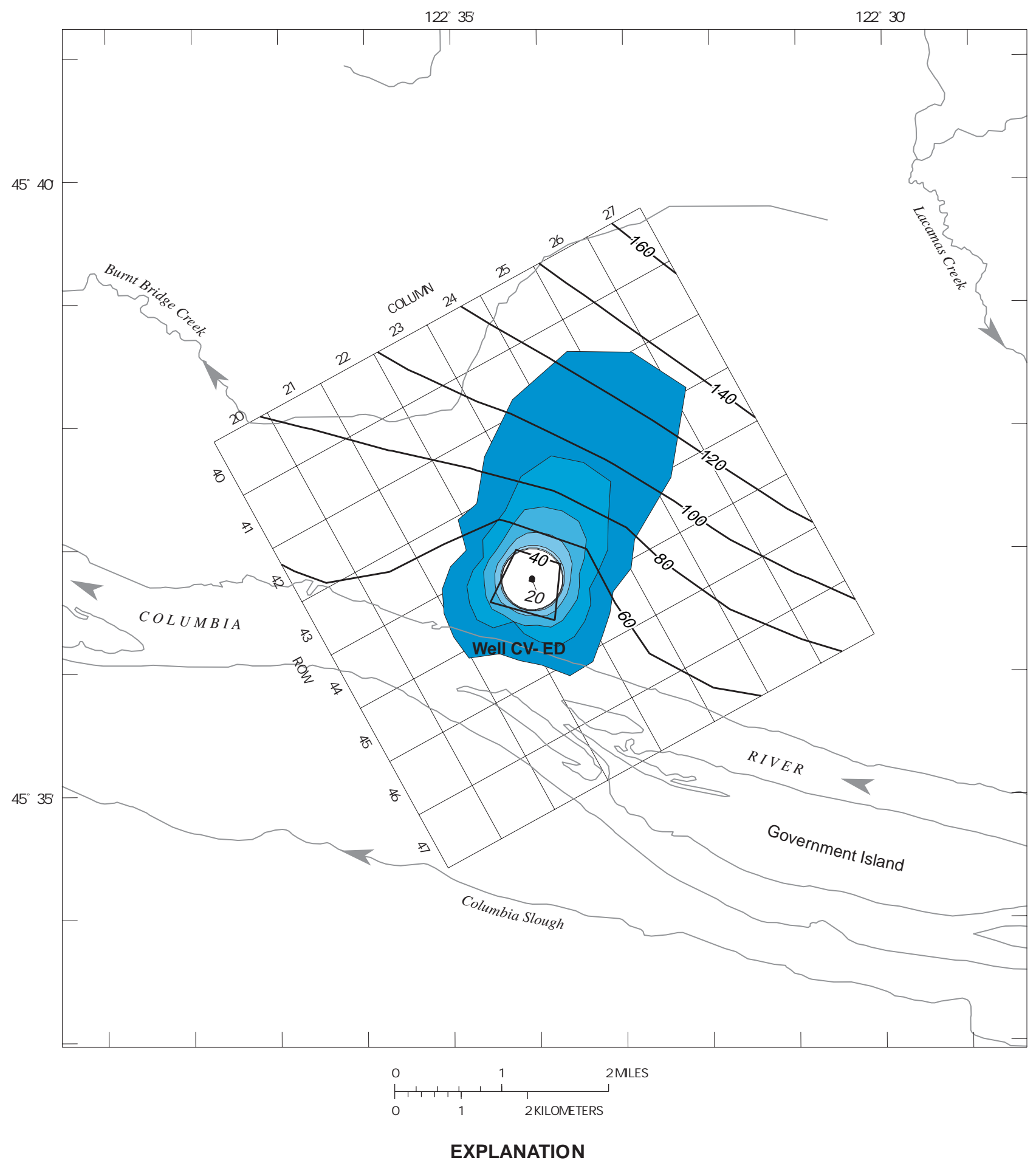

Zones of transport-value indicates time of travel in years.
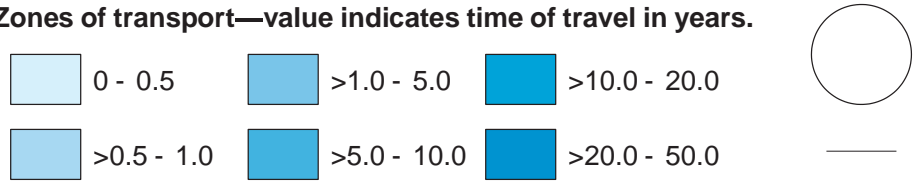

Particle starting area

Model cell boundary
Line of equal simulated hydraulic head for 1987-88 in model layer 5 . Contour interval 20 feet.

Figure 21. Projected zones of transport for well CV-ED, under baseline conditions (>, greater than; <, less than; =, equal to). 
The areal distribution of ground-water inflow largely determined the extent of each zone. Well CV-ED discharges at a sufficient rate to cause a closed depression in the potentiometric surface in confining unit 2; the depression is manifested by the closed circular lines of equal simulated hydraulic head around the well (fig. 21). As a result, the convergent flow paths near well CV-ED produce wide zones of transport oriented to the northeast.

\section{Zones of Transport and Simulated Water Budget for the Increased-Discharge Simulation}

Compared with baseline conditions, increasing the discharge rate of well CV-ED by a factor of 1.5 increased the size of the zones of transport by 27 percent (table 14). The zones of transport expanded laterally from the cell containing the well relative to the baseline conditions (fig. 22). Particle pathlines indicated that more of the water that discharges from CV-ED passed through the overlying Troutdale sandstone aquifer and the underlying older rocks than in the proposed-conditions simulation. Spatially, particle pathlines north of the well pass through the overlying Troutdale sandstone aquifer and particle pathlines south of the well, toward the Columbia River, pass through confining unit 2, the sand and gravel aquifers, and underlying older rocks.

Increasing the discharge rate of well CV-ED altered the simulated ground-water levels and water budget in the selected group of cells. Simulated ground-water levels declined by an average of about $6 \mathrm{ft}$ from baseline conditions in confining unit 2 and by $30 \mathrm{ft}$ at the well site. The additional recharge needed to meet the increased discharge rate of well CV-ED was gained from an increase in inflow entering from adjacent, overlying, and underlying units and a decrease in discharge leaving the selected group of cells (table 14). Increasing the discharge rate of well CV-ED also affected the simulated ground-water levels and water budget in the overlying aquifers and confining unit 1 resulting in a loss in ground-water discharge to the Columbia River. In summary, under increased-discharge conditions, pumping of well CV-ED diverted water that would have discharged to overlying units and hence to the Columbia River.

\section{Zones of Transport and Simulated Water Budget for the No-Interference Simulation}

When all other discharge but that of well CV-ED was excluded from the model, the size and of all zones of transport for periods of less than 20 years increased because the well was able to capture discharge closer to the well (fig. 22, table 15). The 20 to 50 year zone of transport decreased in size so that the net change in the total area of the zones of transport for times of travel less than 50 years was less than 1 percent. With the removal of other wells, simulated ground-water levels rose by an average of $10 \mathrm{ft}$, and the hydraulic gradient increased toward the Columbia River from baseline conditions. In the absence of well interference, particles used to delineate the zones follow less divergent pathlines, resulting in narrower zones. The simulated water budget changed little relative to baseline conditions in the selected group of cells with the removal of other wells (table 14). Although the greatest percentage of change occurred in the inflow from and outflow to overlying and underlying rocks, the rates of inflow from these sources were an order of magnitude less than the rate of recharge from confining unit 2.

\section{Zones of Transport for Increased-Porosity and Decreased-Porosity Simulations}

The size and shape of the zones of transport delineated for well CV-ED changed significantly under increased-porosity and decreased-porosity conditions (fig. 22, table 15). For increased porosity values, the zones did not extend as far from well CV-ED because ground water moved to the well more slowly than under baseline conditions, which reduced the total area by 34 percent. For decreased porosity values, the zones extended farther from well CV-ED because ground water moved to the well more rapidly than under baseline conditions, which increased the total area by 65 percent. The magnitude of these changes in area was influenced by the fact that all of that water that discharges from well CV-ED is older than 50 years.

\section{Zones of Transport and the Simulated Water Budget for Increased-Conductivity and Decreased-Conductivity Simulations}

Varying the horizontal hydraulic conductivity from the proposed simulation caused changes in the simulated ground-water flow system and in the water budget (fig. 22, table 14). The zones extended slightly farther from well CV-ED than under baseline conditions because ground water moves to the well more rapidly than under baseline conditions. The total area enclosed by the zones increased by nearly 4 percent 
INCREASED DISCHARGE

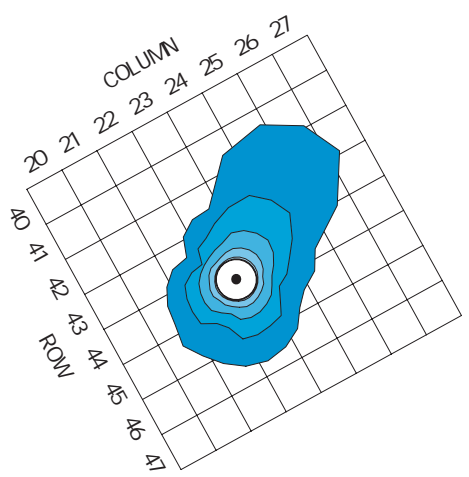

INCREASED POROSITY

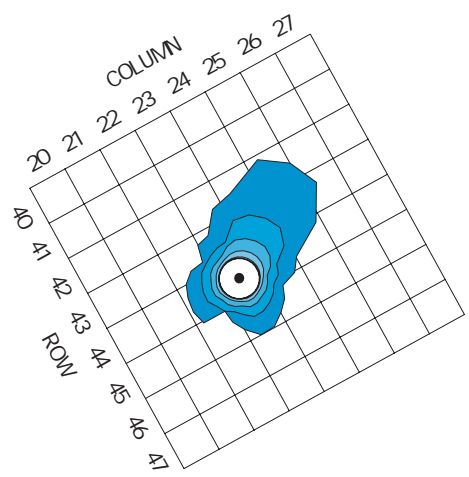

KILOMETERS

\section{INCREASED CONDUCTIVITY}

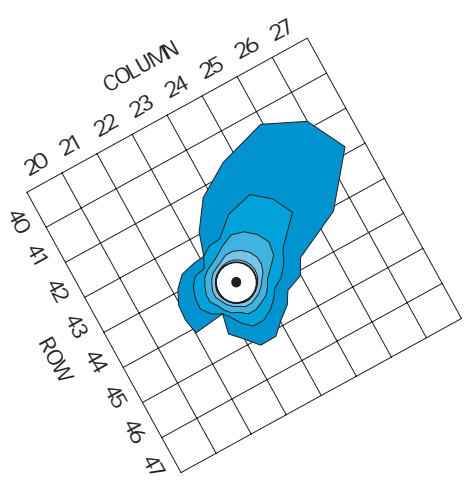

NO INTERFERENCE

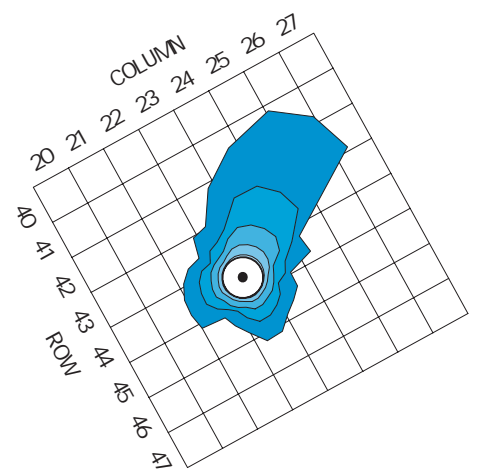

\section{DECREASED POROSITY}

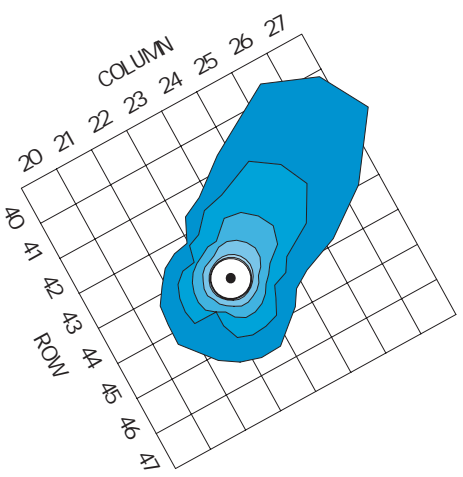

\section{DECREASED CONDUCTIVITY}

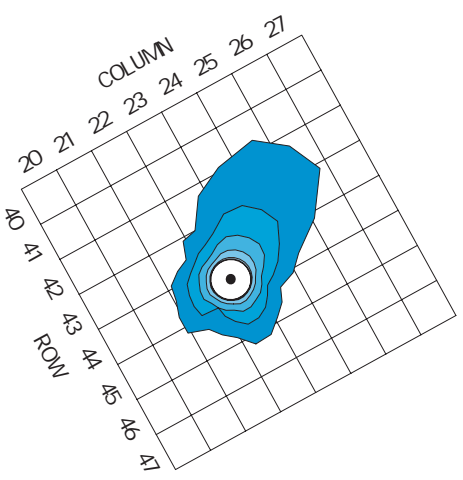

Zones of transport-value indicates time of travel in years.

$\square=0.5 \square>1.0-5.0 \square>10.0-20.0$
$\square>0.5-1.0 \square>5.0-10.0 \square>20.0-50.0$

EXPLANATION

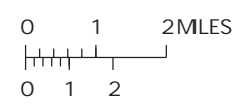

Figure 22. Projected zones of transport for well CV-ED, under different simulated hydrologic conditions (>, greater than; <, less than; =, equal to). 
Table 15. Areas of projected zones of transport from different simulations for well CV-ED

\begin{tabular}{|c|c|c|c|c|c|c|c|c|c|c|c|c|c|c|}
\hline \multirow[b]{3}{*}{$\begin{array}{c}\begin{array}{c}\text { Time } \\
\text { (years) }\end{array} \\
\end{array}$} & \multicolumn{2}{|c|}{ Baseline } & \multicolumn{2}{|c|}{ Increased-discharge } & \multicolumn{2}{|c|}{ No-Interference } & \multicolumn{2}{|c|}{ Increased-porosity } & \multicolumn{2}{|c|}{ Decreased-porosity } & \multicolumn{2}{|c|}{ Increased-conductivity } & \multicolumn{2}{|c|}{ Decreased-conductivity } \\
\hline & \multirow[b]{2}{*}{ Area $^{1}$} & \multirow[b]{2}{*}{$\begin{array}{c}\text { Cumulative } \\
\text { area }^{2}\end{array}$} & \multicolumn{2}{|c|}{ Percent change } & \multicolumn{2}{|c|}{ Percent change } & \multicolumn{2}{|c|}{ Percent change } & \multicolumn{2}{|c|}{ Percent change } & \multicolumn{2}{|c|}{ Percent change } & \multicolumn{2}{|c|}{ Percent change } \\
\hline & & & Area $^{3}$ & $\begin{array}{c}\text { Cumulative } \\
\text { area }^{4}\end{array}$ & Area $^{3}$ & $\begin{array}{c}\text { Cumulative } \\
\text { area }^{4}\end{array}$ & Area $^{3}$ & $\begin{array}{c}\text { Cumulative } \\
\text { area }^{4}\end{array}$ & Area $^{3}$ & $\begin{array}{c}\text { Cumulative } \\
\text { area }^{4}\end{array}$ & Area $^{3}$ & $\begin{array}{c}\text { Cumulative } \\
\text { area }^{4}\end{array}$ & Area $^{3}$ & $\begin{array}{c}\text { Cumulative } \\
\text { area }^{4}\end{array}$ \\
\hline 0.5 & 11 & 225 & 35.6 & 1.8 & 7.8 & 0.4 & -30.8 & -1.6 & 73.5 & 3.7 & 4.5 & 0.2 & -4.8 & -0.2 \\
\hline 1 & 21 & 246 & 37.1 & 4.9 & 10.2 & 1.2 & -28.7 & -3.9 & 82.6 & 10.6 & 6.8 & .8 & -5.5 & -.7 \\
\hline 5 & 131 & 377 & 36.2 & 15.8 & 9.4 & 4.1 & -32.2 & -13.7 & 80.6 & 34.9 & 5.3 & 2.4 & -7.5 & -3.1 \\
\hline 10 & 311 & 688 & 37.2 & 25.5 & 7.3 & 5.5 & -32.2 & -22.1 & 84.8 & 57.5 & 6.1 & 4.0 & -6.3 & -4.5 \\
\hline 20 & 708 & 1,396 & 39.8 & 32.7 & 10.7 & 8.2 & -32.3 & -27.2 & 104.3 & 81.2 & 4.8 & 4.4 & -5.6 & -5.1 \\
\hline 50 & 2,434 & 3,830 & 23.8 & 27.0 & -3.9 & .5 & -37.8 & -33.9 & 55.2 & 64.7 & 3.4 & 3.8 & -12.2 & -9.6 \\
\hline
\end{tabular}

1 The area of the projected zones of transport for each selected time of travel for the baseline simulation, (in square feet times $10^{-4}$ ).

2 Summation of areas for this and all previous time steps for the baseline simulation, including the starting area, (in square feet times $10^{-4}$ ).

3 Percent change in area is the area for a simulation minus the area for the baseline simulation divided by the area for the baseline simulation.

4 Percent change in cumulative area is the cumulative area of a simulation minus the area of the baseline simulation divided by the area of the baseline simulation. 
Simulated water level in confining unit 2 declined by an average of about $3 \mathrm{ft}$ in the vicinity of well CV-ED and rose by $6 \mathrm{ft}$ at the well site. Also, changes in the water budget, especially in the rate of lateral inflow and outflow in confining unit 2 in the selected group of cells, resulted from the expansion in the zones of transport for well CV-ED.

Under decreased horizontal hydraulic conductivity conditions, the zones did not extend as far from well CV-ED as under baseline conditions because ground water moved to the well more slowly. The total area enclosed by the zones decreased by nearly 10 percent. Simulated water levels in confining unit 2 rose by an average of about $3 \mathrm{ft}$ in the vicinity of well $\mathrm{CV}$-ED and declined by $10 \mathrm{ft}$ at the well site. Also, changes in the water budget, especially in the rate of inflow to and outflow from confining unit 2 in the selected group of cells, resulted from the reduction in the zones of transport for well CV-ED.

\section{Summary of Simulation Scenarios for Well CV-ED}

Under baseline conditions, the zones of transport to CV-ED extend to the northeast, generally following the trend in the hydraulic gradient within confining unit 2 and the sand and gravel aquifer. The zones of transport for well CV-ED were delineated for times of travel up to 50 years. Results of the particletracking analysis from the simulation of baseline conditions indicated that the water that discharges from well CV-ED recharged confining unit 2 and the sand and gravel aquifer more than 50 years before. The principal factor influencing the shape of the zones of transport is the convergent flow paths to well CPU-19, which resulted in progressively wider zones for greater times of travel. Particle pathlines north of the well indicated that the water from the north that discharged from well CV-ED passed through the overlying Troutdale sandstone aquifer. Particle pathlines south of the well, toward the Columbia River, indicated that the water from the south that discharged from well CV-ED passed through confining unit 2, the sand and gravel aquifers, and underlying older rocks. Pumping of well CV-ED would divert water that would otherwise discharge to overlying cells and hence to the Columbia River.

Uncertainty in the porosity of confining unit 2 and other units in the vicinity of well CV-ED contributed more to the uncertainty in delineating the zones of transport for CV-ED than did uncertainty in other factors. Uncertainty in other factors, such as well discharge rate and horizontal hydraulic conductivity, had measurable effects on the zones of transport, but errors introduced through these factors were less significant. Changing the porosity by multiplying by 0.8 and 1.2 produced the greatest change in the size of the zones delineated for this well relative to those under baseline conditions by influencing particle velocities.

Increasing the discharge from well CV-ED by multiplying by 1.5 resulted in expansion of the zones of transport relative to the proposed simulation. The zones extended farther from well CV-ED, especially toward the Columbia River. Increasing the discharge rate produced the greatest changes in the simulated water budget.

Uncertainty in the withdrawal rates of nearby wells would have a minimal effect on the zones of transport delineated for well CV-ED. Excluding all discharge from other wells produced the greatest change in the simulated water level budget but the least change in the total area enclosed by the zones of transport relative to the baseline simulation. However, excluding all discharge from other wells produced the greatest change in the shape of the zones of transport for well CV-ED relative to baseline conditions. Particle pathlines indicated that flow paths to the well were less convergent, resulting in narrower zones extending away well CV-ED for greater times of travel.

\section{SUMMARY AND CONCLUSIONS}

This report describes a technique of delineating zones of transport for wells. Zones of transport are three-dimensional zones of contribution for specified times of travel. Six wells in Clark County, Washington, were selected to demonstrate the technique. Zones of transport were generated for times of travel of 0 to $0.5,0.5$ to 1,1 to 5,5 to 10,10 to 20 , and 20 to 50 years for the selected wells. Zones of transport for wells are affected by many hydrologic factors, including the well discharge rate, interfering wells, porosity, and horizontal hydraulic conductivity. The effect of these factors on hydrologic conditions in the Portland Basin was simulated by using a ground-water flow model (Morgan and McFarland, 1996). Some of these conditions may not be simulated in other ground-water flow models, but the methodology described in this report can be applied using any ground-water flow model. The ground-water flow model used in this study was the U.S. Geological Survey modular threedimensional finite-difference ground-water flow model (MODFLOW) with modifications to read geographic information system files (MODFLOWARC). 
The U.S. Geological Survey three-dimensional particle-tracking post-processing program

MODPATH was used to calculate the advective threedimensional movement of hypothetical water particles through a simulated ground-water flow system at specified points in time. The U.S. Geological Survey Geographic Information System post-processing program (MODTOOLS) was used to construct the zones of transport for each well from the particle locations and characteristics output by MODPATH at specified times of travel. The results of this study are subject to the limitations and assumptions inherent in simulating physical systems with numerical models and those specific to the Portland Basin model.

The Portland Basin model is a steady-state model calibrated to time-averaged conditions for the $1987-88$ period. The Portland Basin model simulated stratigraphically complex, heterogeneous, anisotropic aquifers that were connected to complex networks of streams and that were stressed by multiple, simultaneously discharging wells. The model was calibrated by comparing simulated water levels and stream discharge to measured values. A transient model was not constructed due to the lack of data documenting historical changes in stress (recharge and pumpage) on the ground-water system and hydrologic response of the system (changes in water levels and discharge to streams).

To illustrate the effects of varying hydrologic conditions in different parts of the Portland Basin model, the following wells and conditions were simulated: (1) Town of Battle Ground Well 1 (BG-1), where the effects from interfering wells were negligible and the discharge rate of this well was low when compared to other wells, (2) City of Vancouver Well 4.1 (CV-4.1), where the effects from interfering wells were significant and the discharge rate of this well was high when compared with other wells, (3 and 4) Clark Public Utility Well 19 (CPU-19) and Clark Public Utility Well 9 (CPU-9), where the discharge rates of both wells were reasonably close and the wells were in close proximity (within five model grid cells) but hydrologic conditions were different, (5) City of Vancouver Well 9 (CV-9.6), where the well intercepted water in different flow regimes, from local groundwater flow to deep regional ground-water flow, and (6) City of Vancouver Ellsworth Deep Well (CV-ED), a proposed site at the time of the study, where the well would withdraw water from a confined aquifer.

Zones of transport in this report are estimates, because each zone was delineated using a group of particles that had followed pathlines farthest from the well in the $x-y$ plane of the model grid at a specified time of travel (Orzol, 1997). The sensitivity of the zones to changes in model boundary conditions and parameters indicates how uncertainties in these data may cause errors in the size and shape of these zones. In this study the effects of uncertainty in (1) the discharge rate of the well, (2) the discharge of all other wells except the selected well, (3) porosity, and (4) horizontal hydraulic conductivity were evaluated. The effect of varying recharge from precipitation and drywells was not evaluated in this report, and recharge was held constant during all simulations.

The simulated water budget and simulated ground-water levels in a selected group of cells surrounding each well under baseline conditions were compared with water budgets and ground-water levels for each of the simulated conditions. Insight into the causes of the changes in the size and shape of the zones of transport to varying conditions was gained by evaluating the simulated water budget and groundwater levels in the selected group of cells. Changes in the simulated water budget and ground-water levels in different simulations provided information to better understand the hydrologic effects of uncertainties in the data. Conclusions drawn from this study are listed below:

1. Ground-water velocity is the underlying control on the size of the zones of transport.

2. The regional hydraulic gradient is the most significant factor controlling the shape and orientation of the zones of transport. Spatial variation in recharge, discharge, and hydraulic properties can also affect the shape of the zones of transport, however.

3. Underestimating porosity or overestimating horizontal hydraulic conductivity leads to overestimating ground-water velocity and overestimating the size of zones of transport.

4. Overestimating porosity or underestimating horizontal hydraulic conductivity leads to underestimating ground-water velocity and underestimating the size of zones of transport.

5. Well discharge rate affects ground-water velocities near the well. Underestimating discharge (and therefore velocities) will result in underestimating the size of the zones of transport.

6. The sensitivity of estimated zones of transport to uncertainty in parameters, such as porosity and horizontal hydraulic conductivity, is a function of the well discharge rate and the proximity of the well to boundaries, such as streams and rivers. 


\section{SELECTED REFERENCES}

Ahuja, L.R., Cassel, D.K., Bruce, R.R., and Barnes, B.B., 1989, Evaluation of spatial distribution of hydraulic conductivity using effective porosity data: Soil Science, v. 148, no. 6, p. 404-411.

Bair, E.S., and Roadcap, G.S., 1992, Comparison of flow models used to delineate capture zones to wells-1. Leaky-confined fractured-carbonate aquifer: Ground Water, v. 30, no. 2, p. 199-211.

Bair, E.S., Sheets, R.A., and Eberts, S.M., 1990, Particletracking analysis of flow paths and traveltimes from hypothetical spill sites within the capture area of a wellfield: Ground Water, v. 28, no. 6, p. 884-892.

Bair, E.S., Springer, A.E., and Roadcap, G.S., 1991, Delineation of traveltime-related capture areas of wells using analytical flow models and particletracking analysis: Ground Water, v. 29, no. 3, p. 387-397.

Barlow, P.M., 1989, Delineation of contributing areas to public supply wells in stratified glacial-drift aquifers, in Protection of ground water from the bottom up-Local responses to wellhead protection: Conference Proceedings, October 2-3, 1989, Danvers, Massachusetts, U.S. Environmental Protection Agency, p. 145-164. 1993, Particle-tracking analysis of contributing areas of public-supply wells in simple and complex flow systems, Cape Cod, Massachusetts: U.S. Geological Survey Open-File Report 93-159, $68 \mathrm{p}$.

Bauer, H.H., and Vaccaro, J.J., 1987, Documentation of a deep percolation model for estimating ground-water recharge: U.S. Geological Survey Open-File Report 86-536, $180 \mathrm{p}$.

Blandford, T.N., and Huyakorn, P.S., 1990, A modular semi-analytical model for the delineation of wellhead protection areas: Washington, D.C, U.S. Environmental Protection Agency, Office of Ground-Water Protection, [variously paged].

Brown, R.H., 1963, The cone of depression and the area of diversion around a discharging well in an infinite strip aquifer subject to uniform recharge:

U.S. Geological Survey Water-Supply Paper 1545-C, p. C69-C85.

Buxton, H.T., Reilly, T.E., Pollock, D.W., and Smolensky, D.A., 1991, Particle tracking analysis of recharge areas on Long Island, New York: Ground Water, v. 29 , no. 1 , p. $63-71$.

Collins, C.A., and Broad, T.M., 1993, Estimated average annual ground-water pumpage in the Portland Basin, Oregon and Washington, 1987-88: U.S. Geological Survey Water-Resources Investigations Report 91-4018, $24 \mathrm{p}$.

DaCosta, J.A., and Bennett, R.R., 1960, The pattern of flow in the vicinity of a recharging and discharging pair of wells in an aquifer having areal parallel flow: International Association of Scientific Hydrology, Publication no. 52, p. 524-536.

Delin, G.N., and Almendinger, J.E., 1991, Delineation of recharge areas for selected wells in the St. PeterPrairie Du Chien-Jordan aquifer, Rochester, Minnesota: U.S. Geological Survey Open-File Report 90-397, 60 p.

Franke, O.L., and Reilly, T.E., 1987, The effects of boundary conditions on the steady-state response of three hypothetical ground-water systems-Results and implications of numerical experiments: U.S. Geological Survey Water-Supply Paper 2315, 19 p.

Freeze, R.A., and Cherry, J.A., 1979, Groundwater: Englewood Cliffs, New Jersey, Prentice-Hall, Inc., 604 p.

Freeze, R.A., and Witherspoon, P.A., 1967, Theoretical analysis of regional groundwater flow-2. Effect of water-table configuration and subsurface permeability variation: Water Resources Research v. 3, p. 623-634.

Hansen, C.V., 1991, Description and evaluation of selected methods used to delineate wellhead-protection areas around public-supply wells near Mt. Hope, Kansas: U.S. Geological Survey Water-Resources Investigations Report 90-4102, 39 p.

Harbaugh, A.W., 1990a, A compute program for calculating subregional water budgets using results from the U.S. Geological Survey modular three-dimensional finite-difference ground-water flow model: U.S. Geological Survey Open-File Report 90-392, $46 \mathrm{p}$.

1990b, A simple contouring program for gridded data: U.S. Geological Survey Open-File Report 90-144, 37 p.

Hinkle, S.R., and Snyder, D.T., 1997, Chlorofluorocarbonage dating and particle-tracking results of a regional ground-water flow model of the Portland Basin, Oregon and Washington: U.S.Geological Survey Water-Supply Paper 2483, 47 p., 1 pl.

Horsley, S.W., 1983, Delineating zones of contribution of public supply wells to ground water, in Proceeding of the National Water Well Association Eastern Regional Conference, Ground-Water Management: Orlando, Florida, p. 366-392.

Hutchinson, C.B., 1990, Analysis of ground-water flow in the A-sand aquifer at Paramaribo, Suriname, South America: U.S. Geological Survey Water-Resources Investigations Report 90-4036, 65 p.

Jacob, C.E., 1950, Flow of ground water, Chapter 5, in Rouse, H., ed., Engineering hydraulics: John Wiley, p. 321-386.

Keely, J.F., 1984, Optimizing pumping strategies for contaminant studies and remedial actions: Ground Water Monitoring Review, v. 4, no. 3, p. 63-74. 
Konikow, L.F., and Bredehoeft, J.D., 1978, Computer model of two-dimensional solute transport and dispersion in ground water: U.S. Geological Survey Techniques of Water-Resources Investigations, book 7, chap. C2, 90 p.

Lang, S.M., 1963, Drawdown patterns in aquifers having a straight-line boundary: U.S. Geological Survey Water-Supply Paper 1545-C, p. C56-C68.

Martinko, E.E., Merchant, J.W., Whittemore, D.O., and Whistler, J.L., 1987, Development of a prototype geographic information system for groundwater quality protection in Kansas-Final report: Lawrence, Kansas, Applied Remote Sensing Program, July 1987, 160 p.

Mazzaferro, D.L., 1989, Estimation of the recharge area of a pumped, stratified-drift aquifer in Connecticut by simulation modeling: U.S. Geological Survey WaterResources Investigations Report 87-4124, 100 p.

Mazzaferro, D.L., Handman, E.H., and Thomas, M.P., 1979, Water resources inventory of Connecticut, pt. 8, Quinnipiac River Basin: Connecticut WaterResources Bulletin, no. 27, 88 p.

McCarthy, K.A., and Anderson, D.B., 1990, Ground-water data for the Portland Basin, Oregon and Washington: U.S. Geological Survey Open-File Report 90-126, $56 \mathrm{p}$.

McCarthy, K.A., McFarland, W.D., Wilkinson, J.M., and White, L.D., 1992, The dynamic relationship between ground water and the Columbia River-Using deuterium and oxygen-18 as tracers: Journal of Hydrology, v. 135, no. 1/4, p. 1-12.

McDonald, M.G. and Harbaugh, A.W., 1988, A modular three-dimensional finite-difference ground-water flow model: U.S. Geological Survey Techniques of Water-Resources Investigation, book 6, chap. A1, $586 \mathrm{p}$.

McFarland, W.D., and Morgan, D.S., 1996, Description of the ground-water flow system in the Portland Basin, Oregon and Washington: U.S.Geological Survey Water-Supply Paper 2470-A, 58 p.

Morgan, D.S., and McFarland, W.D., 1996, Simulation of the ground-water flow system in the Portland Basin, Oregon and Washington: U.S.Geological Survey Water-Supply Paper 2470-B, 83 p.

Morris, D.A., and Johnson, A.I., 1967, Summary of hydrologic and physical properties of rock and soil materials, as analyzed by the hydrologic laboratory of the U.S. Geological Survey, 1948-60: U.S. Geological Survey Water-Supply Paper 1839-D, 42 p.

Morrissey, D.J., 1989, Estimation of the recharge area contributing water to a pumped well in a glacial-drift, river-valley aquifer: U.S. Geological Survey WaterSupply Paper 2338, 41 p.

Mundorff, M.J., 1964, Geology and ground-water conditions of Clark County, Washington, with a description of a major alluvial aquifer along the Columbia
River: U.S. Geological Survey Water-Supply Paper 1600, 268 p., 3 pls.

Newsom, J.M., and Wilson, J.L., 1988, Flow of ground water to a well near a stream-Effect of ambient ground-water flow direction: Ground Water, v. 26, no. 6, p. 703-711.

Orzol, L.L., and McGrath T.S., 1992, Modifications to the modular three-dimensional finite-difference groundwater flow model: U.S. Geological Survey Open-File Report 92-50, 202 p.

Orzol, L.L., 1997, User's guide for MODTOOLSComputer programs for translating data of MODFLOW and MODPATH into Geographic Information System files: U.S. Geological Survey Open-File Report 97-240, 86 p.

Pollock, D.W., 1988, Semianalytical computation of path lines finite-difference models: Ground Water, v. 26, no. 6 , p. 743-750.

1989, Documentation of computer programs to compute and display pathlines using results from the U.S. Geological Survey modular threedimensional finite-difference ground-water flow model: U.S. Geological Survey Open-File Report 89-381, $188 \mathrm{p}$.

1994, User's Guide for MODPATH/MODPATH-

PLOT, Version 3-A particle tracking postprocessing package for MODFLOW, the U.S. Geological Survey three-dimensional finite-difference ground-water flow model: U.S. Geological Survey Open-File Report 94-464, [variously paged].

Prickett, H.L., Naymik, T.G., and Lonnquist, C.G., 1981, A "random walk" solute transport model for selected groundwater quality evaluations: Illinois State Water Survey Bulletin 65, 103 p.

Prudic, D.E., 1989, Documentation of a computer program to simulate stream-aquifer relations using a modular three-dimensional finite-difference ground-water flow model: U.S. Geological Survey Open-File Report 88-729, 113 p.

Reilly, T.E., and Pollock, D.W., 1993, Factors affecting areas contributing recharge to wells in shallow aquifers: U.S.Geological Survey Water-Supply Paper 2412.

Rutledge, A.T., 1991, Description of PATH model, in Hansen, C.V., Description and evaluation of selected methods used to delineate wellhead-protection areas around public-supply wells near Mt. Hope, Kansas: U.S. Geological Survey Water-Resources Investigations Report 90-4102, 39 p.

Shafer, J.M., 1986, Program GWPATH, Version 2.1Two dimensional horizontal ground-water pathline analysis, forward or reverse tracking: Champaign, Illinois State Water Survey, February 1986, 58 p. 1987, Reverse pathline calculation of time-related capture zones in nonuniform flow: Ground Water, v. 25 , no. 3 , p. 283-289. 
Snyder, D.T., Wilkinson, J.M., and Orzol, L.L., 1996, Use of a ground-water flow model with particle tracking to evaluate ground-water vulnerability, Clark County, Washington: U.S. Geological Survey OpenFile Report 96-328, $71 \mathrm{p}$.

Snyder, D.T., Morgan, D.S., and McGrath, T.S., 1994, Estimation of ground-water recharge from precipitation, runoff into drywells, and on-site wastedisposal systems within the Portland Basin, Oregon and Washington: U.S. Geological Survey WaterResources Investigations Report 92-4010, 34 p.

Springer, A.E., and Bair, E.S., 1992, Comparison of methods used to delineate capture zones to wells2. Stratified-drift buried-valley aquifer: Ground Water, v. 30, no. 6, p. 908-917.

Stallman, R.W., 1963, Type curves for the solution of single-boundary problems: U.S. Geological Survey Water-Supply Paper 1545-C, p. C45-C47.

Swanson, R.D., 1992, Methods to determine wellhead protection areas for public supply wells in Clark County, Washington: Vancouver, Washington, Clark County Intergovernmental Resource Center, 22 p. and appendices.

Swanson, R.D., McFarland, W.D., Gonthier, J.B., and Wilkinson, J.W., 1993, A description of hydrogeologic units in the Portland Basin, Oregon and
Washington: U.S.Geological Survey WaterResources Investigations Report 90-4196, 62 p.

Theis, C.V., 1938, The significance and nature of the cone of depression in ground-water bodies: Economic Geology, v. 33, no. 8, p. 889-902.

Todd, D.K., 1980, Ground Water Hydrology: New York, John Wiley and Sons, Inc., 200 p.

Tỏ th, J., 1963, A theoretical analysis of groundwater flow in small drainage basin: Journal of Geophysical Research, v. 68, p. 4395-4812.

Trimble, D.E., 1963, Geology of Portland, Oregon, and adjacent areas: U.S.Geological Survey Bulletin 1119, 119 p., 1 pl.

U.S. Environmental Protection Agency, 1987, Guidelines for delineation of wellhead protection areas: Washington, D.C., [variously paged]. -1990, A modular semi-analytical model for delineation of wellhead protection areas: Washington, D.C., [variously paged].

-1991, Delineation of wellhead protection areas in fractured rocks: Washington, D.C., 144 p.

van der Heijd, P., and Beljin, M.S., 1988, Model assessment for delineating wellhead protection areas: Washington, D.C., U.S. Environmental Protection Agency, 271 p. 
